\title{
Progress in palliative care for cancer in Turkey: a review of the literature
}

\author{
Tezer Kutluk ${ }^{1}$, Fahad Ahmed ${ }^{1}$, Mustafa Cemaloğlu ${ }^{1}$, Burça Aydın ${ }^{1}$, Meltem Şengelen ${ }^{2}$, Meral Kirazli ${ }^{1}$, Sema Yurduşen $^{1}$, Richard Sullivan $^{3}$ and \\ Richard Harding ${ }^{4}$
}

${ }^{1}$ Department of Pediatric Oncology, Hacettepe University Faculty of Medicine and Cancer Institute, 06100 Ankara, Turkey

${ }^{2}$ Department of Public Health, Hacettepe University Faculty of Medicine, 06100 Ankara, Turkey

${ }^{3}$ King's College London, Institute of Cancer Policy, Conflict \& Health Research Group, London, UK

${ }^{4}$ Florence Nightingale Faculty of Nursing, Midwifery and Palliative Care, Cicely Saunders Institute, King's College London, London, UK

\section{Abstract}

Background: The demographic transition in Turkey is shifting the burden of diseases towards non-communicable diseases including cancer. Palliative care (PC) as a component of Universal Health Coverage assures patient and family-centred care provision throughout the spectrum of cancer.

Objectives: This study aimed to make a detailed evaluation of the progress achieved since the mid-90s and the current situation of cancer PC in Turkey.

Methods: A literature review was conducted in PubMed, Scopus, Embase, ScienceDirect, Web of Science, Google Scholar, The Turkish Academic Network and Information Centre databases, Ministry of Health documents, Council of Higher Education's thesis 01/1995 to $07 / 2020$. The information was categorised into the six domains: history of the cancer PC; law and regulations; education and research; opioid use; patient care and palliative centres; public awareness, psychosocial support and end of life ethics.

Results: Of 27,489 studies, 331 met the inclusion criteria. The majority were published in the Turkish language and were journal articles. The findings showed that the development of PC in Turkey can be divided into three stages: early initiatives before 2000, the dissemination stage, 2000-2010 and the advanced stage after 2010. There is evidence of progress in terms of legal regulations, opioid use and number of PC services and research output. However, there is still a need for improvement in professional education, public awareness and end of life care.

Conclusion: There is evidence of progress, barriers and opportunities. However, bringing research into practice is needed for scale-up and integration of PC in cancer care in Turkey.

Keywords: palliative care, cancer, capacity building, systematic review, Turkey

\section{Background}

Demographic and disease transition has amplified the challenges for cancer care globally [1-3]. Palliative care (PC) aims to relieve the suffering of patients facing life-limiting conditions. Although PC is a newer component in the modern healthcare system, it is
Correspondence to: Tezer Kutluk Email: tezerkutluk@gmail.com

ecancer 2021, 15:1321

https://doi.org/10.3332/ecancer.2021.1321

Published: 25/11/2021

Received: 09/10/2021

Copyright: (c) the authors; licensee ecancermedicalscience. This is an Open Access article distributed under the terms of the Creative Commons Attribution License (http:// creativecommons.org/licenses/by/4.0), which permits unrestricted use, distribution, and reproduction in any medium, provided the original work is properly cited. 
increasingly recognised as an essential part of it. The PC resolution adopted at the World Health Assembly in May 2014, urged governments to 'integrate palliative care services in the continuum of care, across all levels, with emphasis on primary care, community and home-base care, and universal health coverage (UHC) schemes' [4]. Moreover, the recommendations of the Worldwide Palliative Care Alliance stress that all governments must integrate PC along with preventive and curative health care into their national health system [5].

It is estimated that more than 56.8 million people need end of life PC every year globally [5]. If it is considered that for every terminally ill patient requiring PC, there are at least one or two caregivers involved, the total need of PC will be twice or thrice than the above estimates. Owing to physical symptoms, psycho-social and treatment effects, cancer patients are in greater need of PC and it is estimated that cancer patients only require more than one-quarter of global PC need [5].

Considering the need of PC, it is also worth noting that only a few countries have comprehensive PC programmes through a public health approach [6]. According to the most recent global survey conducted among 194 countries, funding for PC was available in $68 \%$ of countries and only $40 \%$ of countries reported that the PC services reached at least half of the patients in need [7].

Turkey is home to about 83.6 million people [8] and additionally hosts about 3.6 million refugees [9]. Based on the Global Cancer Observatory (GLOBOCAN) 2020 data, the estimated number of annual cancer cases in Turkey is 233,834 and 126,335 people die due to cancer [10]. Considering the burden of cancer and other non-communicable diseases (NCDs) along with an increase in life expectancy at birth [11], the real need for PC will be much greater in the near future. The concept of PC was developed in Turkey along with the cancer control programme. The Turkish Ministry of Health $(\mathrm{MoH})$ had brought together all stakeholders under the umbrella of a National Cancer Advisory Board and ignited the Palliaturk project which became a turning point to create a national policy for PC [12]. Despite the decade long effort for establishment of the national PC programme and the progress which has been made, it is widely acknowledged that there is still a need for improvement for further dissemination and to take PC to a higher level in Turkey [13]. The aim of this review is to make a detailed evaluation of the progress achieved since the mid-90s and the current situation of cancer PC in Turkey.

\section{Method}

\section{Search strategy}

The methods for this review were based on Arksey and O'Malley's scoping review methodology [14]. The databases were retrieved through a search of MEDLINE, Scopus, Embase, ScienceDirect and Web of Science, Google Scholar, ULAKBIM (The Turkish Academic Network and Information Centre), Turkish MoH documents, The Thesis Database of the Turkish Council of Higher Education and renowned national and international PC as well as cancer conferences. Articles were explored for PC for cancer patients in Turkey. The search was made by using three Medical Subject Headings (MeSH) categories - palliative care (palliative care, palliative therapy, end of life care, terminal care, supportive care, palliative medicine), cancer (cancer, oncology, malignancy, neoplasm, tumours, neoplasia) and Turkey (Turkey, Turkish) - combined using 'and' statements. The local database was also searched using the translation of the above term in Turkish. The search was limited to literature published between the year 01/1995 and 07/2020. Searches were performed on article titles, abstracts and full text. Additional studies were identified through the references of relevant studies.

\section{Data selection procedure}

Articles/studies were included in the review if they were in either the English or Turkish language and focused on PC in cancer. Articles which did not focus on Turkey, or were focused on surgical or radiological interventions for palliation of symptoms were excluded. Following the database search, duplicates were removed. Titles and abstracts were inspected jointly by all authors for inclusion in the review. Irrelevant studies were removed and the full text was examined if necessary. A Preferred Reporting Items for Systematic Reviews and Meta-Analyses (PRISMA) flow diagram was used to provide information regarding the selection of the articles in this review. 


\section{Data extraction and analysis}

The following information was extracted from articles: author names, the institution of affiliation of the first and corresponding author, title, name of the journal/conference/publisher, year of publication, type of publication, language of the article, study design and setting, national or international collaboration, aim/objective of the study, aspect of PC being studied and the main findings.

The main text of all articles included in this review was read by authors independently, the key findings were extracted and assigned into categories. Later these categories were examined and conceptualised in the research team meetings and were condensed into major themes; history of PC in Turkey, law and regulations, education \& training, research trend, pain management, patient care and psychosocial support. The summary findings are presented in the results section.

\section{Results}

\section{Search results}

A total of 27,489 papers (7,989 research papers, 19,388 abstracts of conference presentation/poster, 101 postgraduate theses and 11 governmental documents) were identified. After removing duplicates, 24,788 papers met the condition for full-text screening. In all, 24,374 pieces of literature (the large majority of conference abstracts) were excluded based on the title or abstract. The remaining 414 were retrieved and screened in detail. Out of these, 83 were removed (there was insufficient information regarding PC for cancer in the full text of 67 literatures, five studies were specific to ethical considerations at the end of life, four were about the specific surgical procedures to palliate the obstructive symptoms due to cancer, other four were regarding PC needs of neonates with congenital malformation/birth defects, two studies were regarding geriatric health without cancer, one was about burnout of healthcare workers at oncology services). Figure 1 describes the PRISMA flowchart of the literature reviewed in this study and the details of the included 331 articles are shown in Supplementary Table 1.

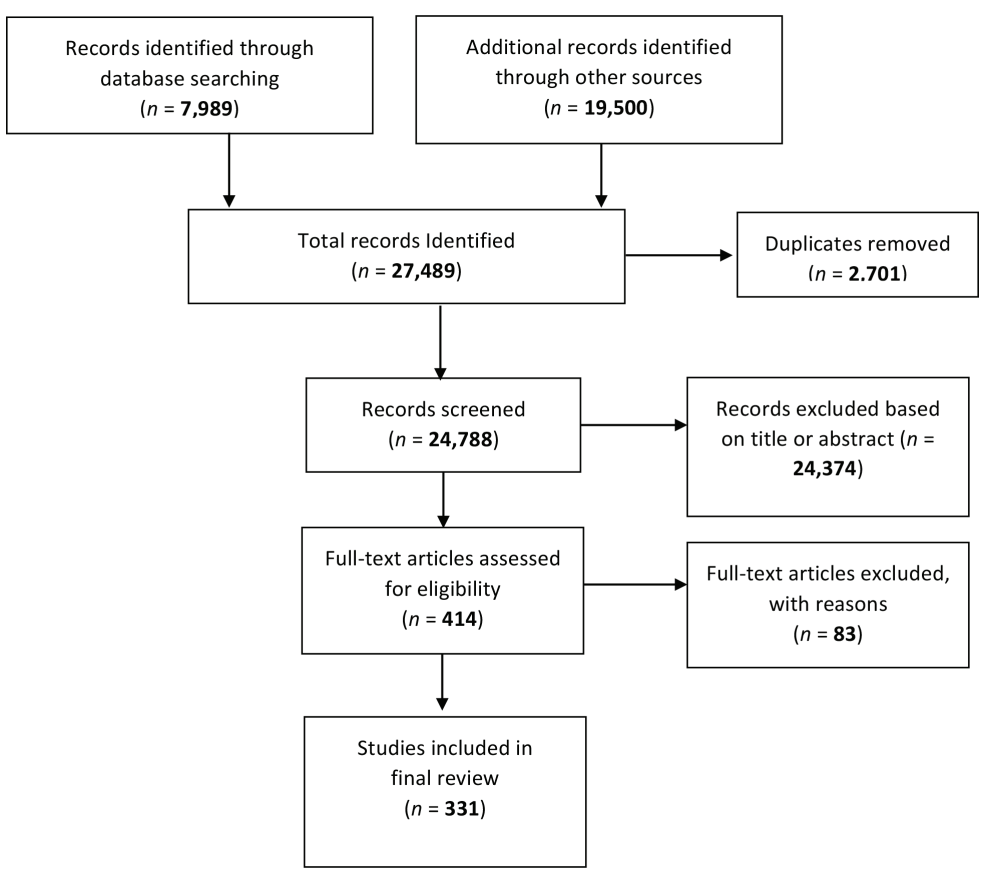

Figure 1. PRISMA flowchart. 


\section{Characteristics of included studies}

Of these 331 articles included in this review, the majority 161 (48.6\%) are journal articles, 96 (29.0\%) conference abstracts, 56 (16.9\%) postgrad theses, 13 (3.9\%) gray literature (mostly from the Turkish Ministry of Health), 3 (0.9\%) book chapters and 2 ( $0.6 \%$ ) are letter to a journal editor. Regarding journal articles - more than half, 98 , articles were published in international journals, whereas 63 were published in Turkish/ national journals.

About 193 (58.3\%) literatures were published in the Turkish language, whereas 138 (41.7\%) were in English. Among all the literature included in this review, 194 (58.6\%) used cross-sectional surveys or retrospective analysis of datasets, 59 (17.8\%) were review articles, letter to the editors, book chapters, 19 (5.7\%) employed either interventional design or randomised control trials or quasi-experimental design, 14 (4.2\%) studies evaluated validity and reliability of specific questionnaires among Turkish PC cancer patients, 13 (3.9\%) were gray literature, 12 (3.6\%) used qualitative research methods, 5 (1.5\%) were case studies or case series evaluating a specific dimension of PC for cancer patients, 4 (1.2\%) employed methodological design, $3(0.9 \%)$ mixed methods research design, $3(0.9 \%)$ articles used either prospective or cohort design and other $3(0.9 \%)$ were cost analysis studies. Only $2(0.6 \%)$ used a case-control design. Furthermore, 11 articles were published in collaboration with the Middle East Cancer Consortium (MECC). As shown in Figure 2, only two articles included in this review were published before the year 2000. Most of the articles were published between the year 2018 and 2019. The major themes were presented below.

\section{History of cancer PC in Turkey}

The history of PC in cancer is evaluated in three stages as summarised below and also shown in a timeline (Figure 3).

The first stage: Early initiatives (Before 2000): The earliest available information regarding PC is the establishment of the first outpatient pain unit in Istanbul University in 1986, and the establishment of the Turkish Society of Algology and the launch of the Turkish Journal of Pain in 1987. Soon after, in 1990, an inpatient pain department was established in Istanbul University and in the same year, algology was accepted as a speciality by Higher Education Council [15].

By the end of the 90s, there were no modern PC services. A lack of trained health care professionals, low public/professional awareness, limited access to opioids and opiophobia were the major barriers [16, 17]. In 2000, 13.1\% of all deaths in Turkey were due to cancer and future projections showed that it would continue to rise [18]. Generally, PC was not a priority. By 2005 , there were only seven supportive care units for pain and symptom management. Opioid consumption was relatively low and physicians as well as pharmacists faced legislative and practical obstacles in prescribing and dispensing opioid analgesics [19].

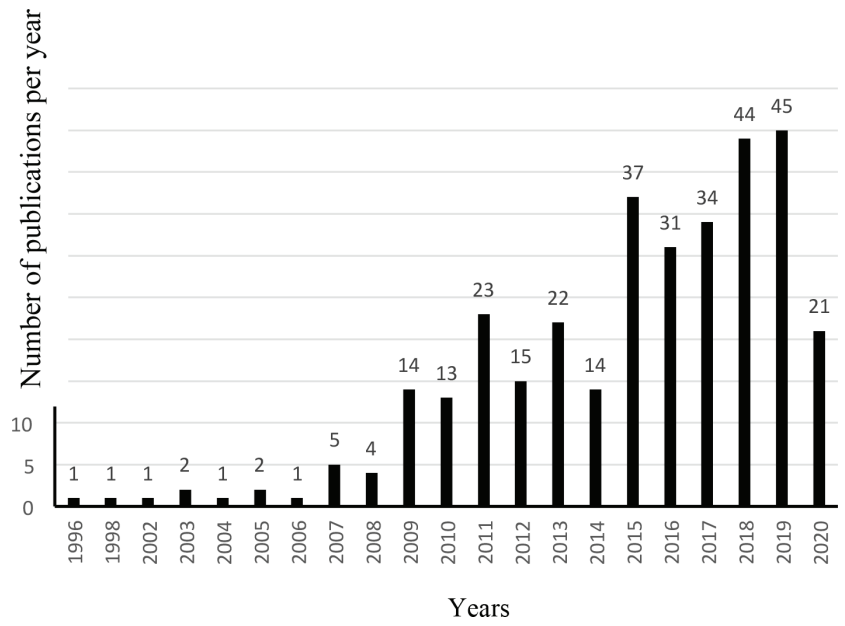

Figure 2. The evolution of the number of articles regarding PC for cancer in Turkey published per year, 1996-2020. 


\section{6-1999}

1986 First outpatient pain unit, Istanbul (15)

1987 Turkish Society of Algology (15) 1987 Turkish Journal of the Pain (15) 1990 The first inpatient pain facility (15) 1990 Department of Algology, Istanbul University (15)

1993 Oncology nursing home $(23,24)$ 1996 MECC establishment (22)

1998 Patient's rights regulation (36)

1998 First PC fellow is trained in USA (16)

1998 First PC fellow is trained in TOG (16)

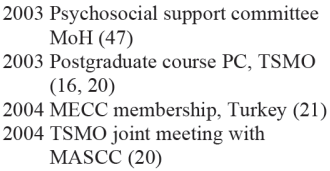

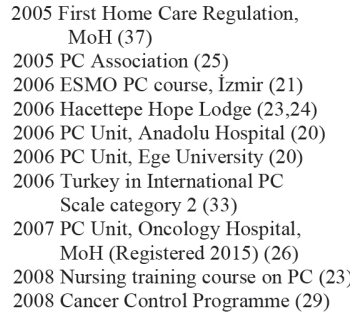

$2015 \mathrm{MoH}$ Palliative Care Directive (39) 2017 Home Care and Palliative Care Section in Dept of Health Services at $\mathrm{MoH}(31,32)$

2019 PC Nurse Society (48)

2020 As of February; 5577 PC bed capacity (137)
Turkey in International PC Scale

2012 Comprehensive PC Center, Ulus State Hospital (23)

2012 PC Practice and Research Centre, 9 Eylül University $(46,134)$ 2014 Inpatient reimbursement (40) 2014 Oral morphine sulphate production (42)

Figure 3. The evolution of the PC in Turkey from the mid-1980s to 2020. PC, Palliative care; MECC, Middle East Cancer Consortium; MASCC, Multinational Association of Supportive Care in Cancer; MoH, Ministry of Health; TOG, Turkish Oncology Group; TSMO, Turkish Society of Medical Oncology; ESMO, European Society of Medical Oncology.

The second stage: Dissemination of PC concept and awareness among the medical and scientific community (2000-2010): The new millennium witnessed interest from governmental and non-governmental stakeholders. The Turkish Oncology Group (TOG) established a supportive care working group in 1999 [16]. The National Cancer Advisory Board of MoH sets a psychosocial sub-committee in 2003. The Turkish Society of Medical Oncology started training courses [16, 20], organised a joint meeting with the Multinational Association of Supportive Care in Cancer (MASCC) in 2004 [20] and the European Society for Medical Oncology (ESMO) in 2006 [21]. The MECC, founded in 1996 in collaboration with $\mathrm{MoH}$ from member countries, became a platform bringing together clinical professionals and researchers [22]. As soon as Turkey became a member of MECC in 2004 [21], MECC \& MoH collaboration started to organise meetings in cancer control including PC courses and workshops. PC awareness and engagement of different stakeholders were raised in the mid-2000s; The establishments of Hope Lodge by Hacettepe University Oncology Institute Foundation in 2006 [23, 24], the Palliative Care Association (PCA) in 2005 [23, 25], PC units in Ege University and Anadolu Hospital in 2006 [20] and a PC unit at MoH Oncology Hospital in 2007 [26] are examples of progress in this period. Based on a survey by $\mathrm{MoH}$ in 2009, there were only $10 \mathrm{PC}$ units and 72 pain units in the country. Morphine use was less than in the USA and many Middle Eastern countries. Legal restrictions and lack of trained PC staff were the major barriers [12, 27, 28].

The third stage: Advancement with government and societal engagement (After 2010): MoH brought the first Cancer Control Programme in 2008 [29]. Soon after, MoH Cancer Control Department started the Palliaturk project in 2010, which was implemented in 2011 [12]. The Palliaturk project had two main objectives - namely targeting the availability of opioids and implementation of a community based PC model $[12,28]$. The model included primary, secondary and tertiary level PC centres. MoH also started collaborations with international and national stakeholders (World Health Organization (WHO), Union for International Cancer Control (UICC), national non-governmental organisations (NGOs) and professional organisations, etc.) [12, 28]. Since the 2010s, new regulations and rules were set by the government; stakeholder involvement and awareness of the medical community as well as the public had increased. New PC centres were opened around the country. In 2015, the 'Palliative Care Nursing Certificate Program' was started by the MoH [30]. In 2017, The Home and Palliative Care section was established under MoH Public Health Directorate [31, 32]. According to the international PC scale ranking, Turkey was in group 2 (capacity-building PC activity) in 2006, and moved up to group 3b (generalised PC provision) in 2011, then in group 3a (isolated PC provision) in 2017. There were no countries except Israel in group 4 from the Middle Eastern Countries [6, 33-35].

\section{Law and regulations}

The major PC regulations and laws were released after 1998. The first regulations relating to patient's rights were released in 1998 [36]. The first home care regulation was released in 2005 [37]. PC services were mentioned in the 2010 update of the home care directive [20, 24, 38]. The first National Cancer Control Programme was released in 2008 [29] and became a turning point - the MoH Cancer Control Department started to work on PC Projects. With the aim of PC provisions, MoH established the PC Directive in 2014 and implemented it in 2015. It became a strong legal support to the establishment of PC centres to provide and promote PC in Turkey [39]. The PC directive described inpatient PC centres within the established hospitals. The involvement of family physicians and home care services in the outpatient setting 
were also included. The PC coverage includes examination, evaluation, care, rehabilitation, psychosocial support, nutritional support, pain management, legal support for the patients \& relatives. Social Security Administration accepted the reimbursement of the inpatient PC costs in 2014 [20, 40]. An update of the home care regulation was released in 2015 [41]. In parallel to this legal progress, the first morphine sulphate tablet was officially produced by a Turkish pharmaceutical company in 2014 [42].

\section{Professional education, training and research}

The first PC fellow of Turkey was a medical oncologist trained in the USA in 1997-1998. Between 2001 and 2010, the Supportive Care in Cancer Committee of the TOG organised 18 national/international training meetings. This committee also contributed to the development of PC within the National Cancer Control Programme after 2008 [16]. Turkish Medical Oncology Society organised the first postgraduate education on PC in 2003, joint meeting with MASCC in 2004, PC course with ESMO in 2006 [20]. More PC courses and meetings have been organised after 2013 by different stakeholders [20]. A nursing academic was trained in the USA for PC in 2006 [20]. MECC \& MoH collaborations became a driving force for PC education in Turkey and regional countries. They jointly organised meetings and workshops between 2004 and 2014, training 434 health care professionals [20-22, 43, 44].

The interest in PC research and education from Medical \& Nursing Schools appeared after 2010. PC lectures were included in Nursing schools under the postgraduate curriculum [20]. PC centres were established in Ege and Dokuz Eylul Universities in 2011 and 2012 , respectively. The centre in Dokuz Eylul University was approved by the Higher Education Council [24, 45, 46].

Stakeholders including the Turkish Medical Oncology Society, the anaesthesiology/algology, nursing community and PCA made a significant contribution. The inclusion of a Psychosocial Committee within the National Cancer Advisory Board in 2003 also helped to increase stakeholders' engagement [47]. In 2019, the Palliative Care Nursing Association was established [48]. The increasing number of reports from various stakeholders including medical specialities [49-51] nurses [20,52-57], physiotherapists [58-62], social workers [47, 63], hospital managers [64], nursing students [65-68] shows the progress in the PC field in Turkey. However, there were an insufficient number of PC healthcare workers. The lack of PC training among medical, nursing, midwifery, students, physicians and nurses, healthcare staff, emergency care staff was within the range of 50\%-80\% [69-83].

The number of research outputs on PC increased after 2015. The different areas of PC were investigated. The need assessment and adaptation of the ENABLE (Educate, Nurture, Advise, Before Life Ends) evidence-based early PC model were also investigated for Turkish family caregivers of older persons with cancer [84]. Ulus State Hospital, MoH first comprehensive PC centre, reported that 38.4\% PC patients had a cancer diagnosis [85]. A previous study found that pain was the most common symptom (27.1\%) among hospitalized patients [86]. Along with an increase in PC services, burnout was also found to be a significant problem among healthcare workers working in PC units [87]. Complementary and alternative medicine (CAM) use is also a common practice in Turkey. CAM use was found to be $57 \%$ among cancer patients [88]. In another study, at least one CAM method was used by 62\% [89]. Irmak et al [90] found that $46.4 \%$ of cancer patients were CAM users, however no significant difference was found with respect to quality-of-life (QoL) score among CAM users and non-users. A randomised trial found that listening to music was effective in controlling pain and anxiety among cancer patients [91]. Several studies focused on the validity, reliability and adaptation of various scales among PC and cancer patients [92-119] (See Supplementary Table 2).

\section{Opioid use and pain management}

Opioid consumption at the global level started to increase in the mid-90s. A survey on the availability and accessibility of opioids among Middle East countries showed that opioid availability was low throughout most of the Middle East countries except Israel. In 2011, Turkey was in the 10th rank as regards morphine consumption mg per capita [120]. For many years, opioids are available but the process for prescribing was complicated with a colour-coded system; red prescription for strong opioids, green for sedatives and weak opioids and white for all non-restricted prescription [16].

Opioid consumption in total morphine equivalence, milligrams per capita, in Turkey in 1980 was 0.0937 and it increased to 12.2204 in 2011. Although there was a significant increase by the time, 2011 Eastern Mediterranean Regional Office (EMRO) average was 10.56, global average was 61.66 [34, 43]. A study published in 2010 showed that the consumption of morphine has been fluctuating at doses around 
$0.1 \mathrm{mg} / \mathrm{capita}$ in Turkey for the period of 2004-2007. This was higher than Saudi Arabia and Egypt but lower than Israel, Cyprus, Jordan and Lebanon. Morphine consumption in Turkey was 447 times less than the USA in 2007. In the USA, the consumption was $76 \mathrm{mg} / \mathrm{capita}$ in the year 2007. The global mean was $5.57 \mathrm{mg} /$ capita [121]. There was a big disparity among the Middle East countries including Turkey in terms of opioid use compared with western World and the USA. Turkey was at number 50th in the world for consumption of opioids analgesics during 2007-2009 [22]. Access to Opioid Medicine in a European Project (ATOME) in 2016 reported that Turkey had more than 40 potential barriers in different categories [122].

A number of studies have been published with a focus on pain management in cancer patients [123-132]. A study among 52 metastatic cancer patients found that the use of morphine was 5.7\%; codeine 3.8\% and tramadol 75\% [130]. In another study, interventional procedure was used to control pain in $11 \%$ of cancer patients [131]. It was also reported that $82 \%$ of hospitalised cancer patients for PC were given different analgesic treatment of whom $50 \%$ received third step pain medicines [124]. A study among 1,467 cancer patients utilising analgesic step ladder approach showed the use of nonopioid+/-weak opioid+strong opioid in 31.5\% and interventional procedures in $14.5 \%$ of patients [125].

\section{Patient care and PC centres}

PC activity was very limited in Turkey before 2010 [21]. The European Association for Palliative Care (EAPC) survey in 2007 showed that PC services are provided in ten centres with a total of 241 beds, and there was only one hospice centre in Turkey. Most of the PC centres were within oncology clinics with a major focus on pain control [133]. The earliest PC units were established in 2006 at Anadolu and Ege University Hospitals [20]. MoH Abdurrahman Yurtaslan Hospital established the comprehensive PC services in 2007 with 18 inpatient beds [26]. New PC centres in MoH Hospitals were established following 2010 [20]. A multidisciplinary PC team in 2010 and first PC unit for children in 2011 were established in Dokuz Eylul University [134, 135]. The first 'Comprehensive PC Center' in the Turkish MoH, Ulus State Hospital was opened in December 2012. One third of patients treated in this centre within a year had a cancer diagnosis [23].

PC services were included in home care services in 2010 [20,38]. By the year 2014, there were a total of 834 home care teams providing services to 416,175 patients. In 2013, there were 18 PC centres in the Turkey [43]. By 2017, the number of PC services increased to 227 PC Units, 947 home care teams and trained 21,696 family physicians within the $\mathrm{MoH}$ organisation [44]. A study in 2018, presented that there were four paediatric PC hospital services in Turkey [136]. As of February 2020, there were 415 PC centres, with 5,577 bed capacity and 6,011 PC workers in 81 Provinces. Among these, there were 10 paediatric PC services with 119 bed capacity. More than 290,000 patients got support from these services [137] (Figure 4).

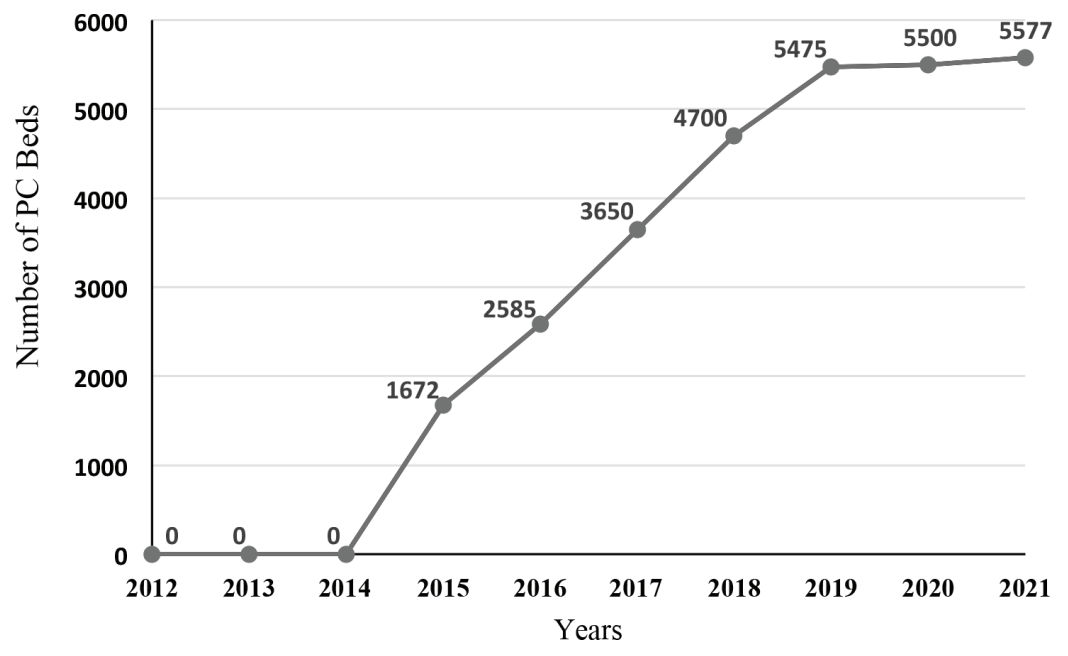

Figure 4. Number of PC beds in Turkey, 2012-2021. 
The increase in PC centres also resulted in an increased number of research outputs. A study showed that $9 \%$ of 214 patients receiving home care health services in Kirikkale city had a diagnosis of cancer [138]. A study reported 45,838 out of 409,337 patients with respiratory problems benefitting from home care services had a diagnosis of lung cancer during 2011-2017 and the number of lung cancer patients increased from 1,346 in 2011 to 9,206 in 2017 [139]. Another study showed that cancer was the fourth most common diagnosis among patients receiving home care services. During the period of 2011 and 2017, total number of home care visits increased from 3,440,144 to 10,917,965; the number of home care teams increased from 593 to 662 . Among home care visits, number of cancer patients increased from 7,278 to $74,261[140]$.

With the increase in the number of services, PC units around the country started to report their experiences [141-145]. Most of the studies focused on symptom management [146-171]. Different aspects of supportive care were investigated in many studies including quality of life [172-181], care dependency [182], nutritional aspects [160, 183, 184]; complementary approaches like acupress [185], reflexology [186], lymphedema management [187], bio-resonance [188] and music therapy [189]. A study from a PC centre showed $87.8 \%$ of 327 patients had cancer during 2015 and 2017. The most common reason for hospitalisation was oral intake impairment in $34.6 \%$, pain control in $25.5 \%$ and both in 16.2\% [190]. Ozcelik et al [191] prepared a PC guideline in 2014. Erkal et al [192] discussed the cost, management, satisfaction and other issues in PC services.

A few studies investigating emergency department admissions showed that 20\%-60\% of patients had a diagnosis of cancer [193-195]. A mortality analysis of 373 stage 4 cancer cases showed that $23.9 \%$ were given chemotherapy during a month before their death [196]. A study investigated the last 2 weeks of 422 terminal cancer patients in hospital; the invasive pain management was used in $25 \%$, terminal sedation in $12 \%$, chemotherapy in $9 \%$, central catheters in 38\%, transfusion in $43 \%$ and MR imaging in $13 \%$ [197]. Another study in cancer patients showed that $42 \%$ of patients were given palliative chemotherapy in the last 3 months of life [198]. There are similar studies that focused on the interventions and investigations during the last weeks of life [199-201]. These studies highlight unnecessary procedures at the terminal stage and emphasise the need for PC among cancer patients.

Symptom control was not at the optimal level. A multicentre study in 1,245 lung cancer patients found that pain was controlled in only $21.7 \%$ cases, while dyspnoea in only $12.4 \%$ of cases [202].

Poor symptom control also affects home based care. A study among caregivers of terminal cancer care presented that most participants expressed that they would like to look after their patients at home, however they preferred hospital care at the end [203]. A study shows that the health literacy level of care givers has a significant effect on bedsore occurrence and survival [204]. A positive correlation between 'the time from diagnosis to palliative care application' and the quality of life was found in a cohort study [205].

An analysis on the nosocomial infections in PC unit showed that the average cost of antibiotics was 1,252.79 $\pm 1,616.50$ Turkish Lira (TRY) [206]. A cost comparison was made among cancer patients treated at comprehensive PC; hospital in-patient PC and home health care services, and it was found that the mean total indirect costs were $\$ 164.10, \$ 778.43, \$ 344.62$, respectively. The mean total direct costs were $\$ 2,384.57$ and $\$ 4,775.68$ in comprehensive palliative care services (CPCC) and hospital inpatient palliative care services (HIS), respectively [207]. A cost analysis in a medical intensive care unit where $77 \%$ of the patients had terminal cancer found that the median cost was 2,841 TRY, and the total cost was 581,353.2 TRY [208]. A cost analysis in Denizli State Hospital PC Centre revealed that total cost of the PC centre was 1.034.235,26 TRY [209]. In another study, the direct cost per patient per day in a PC centre was found as 391 TRY [210].

A survey showed that the patient satisfaction was higher in oncology centres having PC units [211]. A study showed that PC centre was less effective in reducing symptom levels in cancer patients compared with patients in general care at the public hospital, but provided greater patient satisfaction [212].

\section{Public awareness, psychosocial support and end of life ethics}

A low level of public awareness was identified in many studies. It was found that $60 \%-87 \%$ of cancer patients and their caregivers had no prior knowledge about PC [203, 210, 213, 214]. Home care awareness was found as 57\% [119]. Another study presented that patient preference for home care increased from $12 \%$ at admission to $47 \%$ at discharge [215]. Quality of life for care givers was also investigated in a study, and it was found that $53 \%$ of the study subjects did not meet routine responsibilities [216]. 
Do not resuscitate (DNR) is an important element of PC and end of life. However, there is no DNR Law in Turkey. Many researchers stressed the need for legal arrangements for end of life care and DNR policies [20, 217-220].

Along with progress on PC at national level, many studies were conducted on the subjects of psychosocial issues [221-234], patient and professional satisfaction [235-237], burden of the caregivers [238-247] and end of life [248-251]. A survey among doctors and nurses in Middle Eastern Countries including Turkey showed that $44 \%$ of participants provided spiritual care less often than they think they should [252]. A study among PC nurses found that they perceive death as a natural and inevitable process and as their experience increases, they become desensitised [253]. A study showed that $55.7 \%$ of 70 nursing students had never heard of spiritual care [254]. Another study investigating the cultural mourning ritual, the 'First Feast', found this tradition helped to ease the grief response of relatives and might be a useful auxiliary method for PC teams to help grieving families [255]. There are other studies that focus on the psychosocial and spiritual issues on caregivers [256-258].

A study also found that $80 \%$ of the caregivers had inadequate health literacy regarding general health [259]. Barriers for PC development were discussed in some studies [20, 24, 34]. The major barriers reported by Turkish MoH, 2nd Turkish Medical General Assembly Clinical Oncology Study Group were lack of public and professional awareness, failure of PC planning and disconnection from anticancer treatment, hurdles in the accessibility of opioid analgesics, financial issues and the lack of trained PC providers [260].

\section{Discussion}

The population is ageing in Turkey, the proportion of people over 65 years of age comprised $9.5 \%$ of the population in 2020 [8]. The need for PC in Turkey has increased in parallel to the burden of NCDs and cancer. The estimated annual deaths due to NCDs in Turkey was 407,300, it makes $89 \%$ of total deaths in 2016 [261]. Cancer is listed as the second most common cause of mortality which accounts for $18.4 \%$ of all deaths in Turkey during 2019 [262]. There were very limited services mainly provided during the routine care in tertiary care hospitals before 2000. Indeed, the situation was not much different at a global level - it was reported that globally over 56.8 million people are in need of PC each year. Most of them are living in developing countries [5]. The EAPC published that the number of PC beds per million inhabitants was 45-75 in advanced European countries, the rest had few beds [133]. Both professionals (mainly oncologists and anaesthesiologists) and government have contributed on the progress of PC after 2010 significantly in Turkey. The partnership between oncology societies and cancer control department at $\mathrm{MoH}$ became a successful model for the planning and implementation of PC services in Turkey. MoH actions in PC boosted the involvement of other stakeholders, regional/international organisation. The PC activity was scaled up to group $3 \mathrm{~b}$ in 2011. After the implementation of Palliaturk project in 2011, various PC related legal regulations were enacted [6, 12, 33-35]. During the same period, the demand for PC due to changing demographic patterns (ageing, decrease in household size) and burden of cancer/NCDs was also increasing.

Many studies showed that awareness and knowledge about PC among medical professionals was very limited. PC is still not a recognised speciality in Turkey. Only a few universities include PC education in the under and postgraduate curriculum. National and international meetings were the main source of PC training. There is still a large variation in palliative medicine (PM); education even in Europe. In the WHO Europe region, PM courses were included in all medical schools of 13 out of 43 countries, PM was not taught within medical curricula in 14 countries [263]. Major oncology associations like the American Society of Clinical Oncology (ASCO) \& ESMO are also investing in the integration of PC services in oncology [264]. During the last 10 years, PC medicine is gaining more investment from all stakeholders. Sedhom et al [265] commented that PC is still not integrated into cancer care with such a priority focus of oncology training on treatment and research. There is still a strong need for an advanced education and structured human resource policies. An early literature review in Turkey showed the limited PC publications before 2005 [266]. The number of scientific publications and presentations started to increase after 2015; however, most of the studies were either surveys or descriptive studies. More focus on evidence-based research in PC is still needed. A bibliometric analysis on PC during 2000-2016 showed that the publications increased after 2006, the USA and UK were pioneering the scientific work [267].

The use of opioids is being recommended for the control of the pain and improving quality of life [5, 229], and it is used as an indicator for the PC service availability [268]. There were strong critics to Turkey for underuse of opioids for pain management, although Turkey was one of the leading opioid producing countries [34, 43, 121]. The situation improved after the investments on PC starting from 2010, however, it is still 
much lower than the global average [34, 43]. Consumption in defined daily doses for statistical purposes (S-DDD) per million inhabitants per day is within the scale of 201-1,000 during 2014-16 which was less than North America and Europe but higher than most Asian and African countries [269]. Based on our literature review, we can classify the barriers to opioid use into three groups: first is the lack of awareness and opiophobia among the health care professionals and public; second the complexity in prescription of the opioids due to legal procedures and thirdly the lack of organised PC structure until 2010. There is still a need for investments in the infrastructure, training and human resource management on PC under the concept of 'health system strengthening'.

Before the implementation of the Palliaturk project, few hospitals and universities started to invest on PC services, there were no specialised PC centres in those years [20, 21, 23, 26, 43, 133]. The government Palliaturk project, the PC Directive and the Home Care Regulations contributed to the progress made during recent years [12, 20, 39, 41]. Currently, there is a PC section within MoH at top management level and $\mathrm{MoH}$ was able to invest in the dissemination of PC capacity in Turkey [137]. Our findings show that integration for PC services with oncology services is an area for further research and investment. There are a number of cultural barriers and opportunities for the utilisation of PC centres in Turkey. Talking about death is a cultural taboo. Doctors, patients and care givers are reluctant to talk about end of life care. This results in delayed referral to PC centres by professionals. Moreover, the concept of PC centres is not clear in the minds of the public. Therefore, referral to PC centres was sometimes perceived as an abandonment of oncological care. Due to this, patients and caregivers want to be under the care of the primary oncology team instead of PC centres. The integration of PC care into oncology practice will help to overcome these cultural barriers. Traditionally, terminally ill patients were cared for in their homes by family members. However, with social and economic changes, care givers now more commonly prefer their patients to be cared for in the hospital. This could be an opportunity for the utilisation of PC centres more widely. ASCO as a leading professional cancer organisation also strongly advocates the integration of PC into oncology practice to disseminate and implement it more effectively [270].

Currently, there is no DNR Law in Turkey [20, 217]. Moreover, the Turkish society is not ready to implement DNR policies due to several reasons such as health literacy, taboo of discussing death and lack of legal framework. Therefore, DNR is not a priority issue either for the public or government. End of life care and DNR policies must be brought in to the discussion at the public, professional and government level. It is also a time for Turkey to invest in hospice care. The Turkish Society of Internal Medicine also declared that they support Choosing Wisely ${ }^{\circledR}$, a health initiative campaign with recommendations to advance a national dialogue on avoiding unnecessary medical tests, treatments and procedures and 'Do not delay the palliative care' is among the recommendations by this campaign [271]. A recent article by Currow et al [272] discusses the need for transition of hospice care and integration of cancer services with hospices care. It seems the hospice concept will be evolved through the changes in the cancer care in future years.

Now, monitoring the global situation of PC is highly essential. The burden of chronic diseases was in the agenda of UN General Assembly in 2011 and the international organisations/NGO's started to speak more about the need for PC. Due to the increased burden of NCDs including cancers, Turkey must scale up its PC services. One important issue is the effect of the COVID-19 pandemic on cancer care including PC $[273,274]$. An NCD pandemic is a high possibility in the post-COVID-19 period and a greater need of PC is expected.

The International Association for Hospice and Palliative Care re-defined PC as 'Palliative care is the active holistic care of individuals across all ages with serious health-related suffering due to severe illness and especially of those near the end of life. It aims to improve the quality of life of patients, their families and their caregivers' [275].

\section{Conclusion}

In conclusion, this review presents evidence of the significant progress made in Turkey during the last 20 years but also presents the opportunities for further improvement. Bridging the gaps in human resources and training, including PC care as a priority area in the national health agenda, the commitment of all stakeholders, and investing in public and professional awareness should be the focus of the next steps and also shaping the integration of PC in cancer care in Turkey. The inequity in PC must be a priority action for decision makers not only for Turkey but also globally. The stakeholders and decision makers should not neglect the need for PC improvement under the current pressure of the COVID-19 pandemic on health and the economy at a national and global level. 


\section{Conflicts of interest}

The authors declare that there are no conflicts of interest.

\section{Authors' contributions}

TK, FA, MC and MK contributed to the (I) Conception and design, (II) Administrative support, (III) Provision of study materials, (IV) Collection and assembly of data, (V) Data analysis and interpretation, (VI) Manuscript writing: All authors and (VII) Final approval of manuscript.

BA, MŞ and SY contributed to the (I) Conception and design, (III) Provision of study materials, (IV) Collection and assembly of data, (V) Data analysis and interpretation, (VI) Manuscript writing and (VII) Final approval of manuscript.

RS and RH contributed to the (I) Conception and design, (V) Data analysis and interpretation, (VI) Manuscript writing and (VII) Final approval of manuscript.

\section{Funding}

This work was supported by The UK Research and Innovation Global Challenges Research Fund (GCRF) Research for Health in Conflict in the Middle East and North Africa (R4HC-MENA) project; developing capability, partnerships and research in the Middle East and North Africa [ES/P010962/1].

\section{References}

1. United Nations (2017) Department of economic and social affairs, population division World Population Ageing 2017 - Highlights (ST/ ESA/SER.A/397) (New York: United Nations)

2. Sleeman KE, de Brito M, and Etkind S, et al (2019) The escalating global burden of serious health-related suffering: projections to 2060 by world regions, age groups, and health conditions Lancet Global Health 7(7) e883-e892 https://doi.org/10.1016/ S2214-109X(19)30172-X PMID: 31129125 PMCID: 6560023

3. Sleeman KE, Gomes B, and de Brito M, et al (2021) The burden of serious health-related suffering among cancer decedents: global projections study to 2060 Palliat Med 35(1) 231-235 https://doi.org/10.1177/0269216320957561 PMCID: 7797611

4. World Health Assembly 67 (2014) Strengthening of Palliative Care as a Component of Comprehensive Care Throughout the Life Course [https://apps.who.int/iris/handle/10665/162863] Date accessed: 12/12/20

5. Connor SR (2020) Global atlas of palliative care at the end of life World Palliative Care Alliance, World Health Organization Global Atlas of Palliative Care at the End of Life (London: Worldwide Palliative Care Alliance)

6. Connor SR and Sepulveda Bermedo MC (2014) Global Atlas of Palliative Care at the End of Life (London: Worldwide Palliative Care Alliance)

7. World Health Organization (2020) Accessing National Capacity for the Prevention and Control of NCDs [https://www.who.int/ncds/surveillance/ncd-capacity/en/] Date accessed: 12/12/20

8. Turkish Statistical Institution (2020) The Results of Address Based Population Registration System and Numbered 37210 [https://data.tuik. gov.tr/Bulten/Index?p=Adrese-Dayali-Nufus-Kayit-Sistemi-Sonuclari-2020-37210] Date accessed: 4/06/21

9. Directorate General of Migration Management (2020) Temporary Protection [https://en.goc.gov.tr/temporary-protection27] Date accessed: $12 / 12 / 20$ 
10. World Health Organization, and IARC (2020) Global Health Observatory (Turkey: Globocan) [https://gco.iarc.fr/today/data/factsheets/ populations/792-turkey-fact-sheets.pdf] Date accessed: 14/12/20

11. Hacettepe University Institute of Population Studies (2019) 2018 Turkey Demographic and Health Survey (Ankara: Hacettepe University Institute of Population Studies, TR Presidency of Turkey Directorate of Strategy and Budget and TÜBITAK) [http://www.hips.hacettepe. edu.tr/eng/tdhs2018/TDHS_2018_main_report.pdf] Date accessed: 12/12/20

12. Ozgul N, Koc O, and Gultekin M, et al (2011) Opioids for cancer pain: availability, accessibility, and regulatory barriers in Turkey and Pallia-Turk project J Pediatr Hematol Oncol 33(Suppl 1) 29-32 https://doi.org/10.1097/MPH.0b013e3182121bd9

13. Ahmed F, Kirazlı M, and Sengelen M, et al (2020) Palliative care in 2020 \& beyond workshop: a platform to develop palliative care advocacy in Turkey Palliat Med 35(1) 1-243

14. Arksey H and O'Malley L (2005) Scoping studies: towards a methodological framework Int J Soc Res Methodol 8 (1) 19-32 https://doi. org/10.1080/1364557032000119616

15. Erdine S (1996) Turkey: status of cancer pain and palliative care J Pain Symptom Manage 12 139-40 https://doi. org/10.1016/0885-3924(96)00084-X PMID: 8755003

16. Komurcu S (2011) Current status of palliative care in Turkey J Pediatr Hematol Oncol 33(Suppl 1) 78-80 https://doi.org/10.1097/ MPH.0b013e3182122470

17. Kömürcü S (2009) Türkiye'de Palyatif Bakım (palliative care in Turkey) Türkiye'de Kanser Kontrolü (Cancer Control in Turkey) eds M Tuncer, N Özgül, and E Olcayto et al (Ankara: TC Sağlık Bakanlığı) pp 299-304

18. Hajjar RR, Atli T, and Al-Mandhari Z, et al (2013) Prevalence of aging population in the Middle East and its implications on cancer incidence and care Ann Oncol 24(Suppl 7) vii11-24 https://doi.org/10.1093/annonc/mdt268 PMID: 24001758 PMCID: 3767158

19. Bingley A, and Clark D (2009) A comparative review of palliative care development in six countries represented by the Middle East Cancer Consortium (MECC) J Pain Symptom Manage 37(3) 287-296 https://doi.org/10.1016/j.jpainsymman.2008.02.014

20. Can G (2015) The implementation and advancement of palliative care nursing in Turkey J Palliat Care Med S5 001

21. Ozcelik H, Fadiloglu C, and Karabulut B, et al (2010) Palliative care activity in the field of oncology in Turkey J Palliat Care 26(4) 305310 https://doi.org/10.1177/082585971002600408

22. Silbermann M, Arnaout M, and Daher M, et al (2012) Palliative cancer care in Middle Eastern countries: accomplishments and challenges Ann Oncol 23(Suppl 3) 15-28 https://doi.org/10.1093/annonc/mds084 PMID: 22628412 PMCID: 3493144

23. Kabalak AA, Kahveci K, and Gokcinar D, et al (2013) Structuring of palliative care in Ankara Ulus State Hospital, Turkey;2012-2013 J Palliat Care Med 3

24. Gurhan N (2016) Palliative care: its importance and the practice in Turkey Austin Palliat Care 1(1) 1003

25. Palliative Care Association History [http://www.palyatifbakim.org.tr/tarihce.html] Date accessed: 15/01/21

26. Oğuz GT, Şenel GÖ, and Silbermann M (2016) Palliative care unit in an oncology hospital in Turkey Clin Oncol 11157

27. Gültekin M, Özgül N, and Olcayto E, et al (2010) Türkiye'de palyatif bakım hizmetlerinin mevcut durumu Turk J Gynecol Oncol 13(1) 1-6

28. Ozgul N, Gultekin M, and Koc O, et al (2012) Turkish community-based palliative care model: a unique design Ann Oncol 23(Suppl 3) 76-78 https://doi.org/10.1093/annonc/mds093 PMID: 22628421

29. Keskinkılıc B, Gultekin M, and Akarca AS, et al (2016) Turkey Cancer Control Programme (Ankara: Republic of Turkey Ministry of Health Cancer Control Department) [https://www.iccp-portal.org/system/files/plans/Turkiye_Kanser_Kontrol_Program_English.pdf] Date accessed: 4/06/21 
30. Sağlık Bakanlığı Sağlık Hizmetleri Genel Müdürlüğü (2015) Sağlık Alanı Sertifikalı Eğitim Standartları: Palyatif Bakım Hemşireliği (Ankara: Turkish Ministry of Health)

31. The Official Gazette (2017) The presidency of the republic of Turkey Olağanüstü hal Kapsamında Bazı Düzenlemeler Yapılması Hakkında Kanun Hükmünde Kararname [https://www.resmigazete.gov.tr/eskiler/2017/08/20170825-13.pdf] Date accessed: 18/12/20

32. Kamu Hastaneleri Genel Müdürlüğü, and Sağlık Hizmetleri Daire Başkanlığı Evde Sağlık ve Palyatif Bakım Birimi [https://khgmsaglikhizmetleridb.saglik.gov.tr/TR,42977/evde-saglik-ve-palyatif-bakim-birimi.html] Date accessed: 18/12/20

33. Lynch T, Connor S, and Clark D (2013) Mapping levels of palliative care development: a global update J Pain Symptom Manage 45(6):1094-1106 https://doi.org/10.1016/j.jpainsymman.2012.05.011

34. Silbermann M, Fink RM, and Min SJ, et al (2015) Evaluating palliative care needs in Middle Eastern countries J Palliat Med 18(1) 18-25 https://doi.org/10.1089/jpm.2014.0194

35. Clark D, Baur N, and Clelland D, et al (2020) Mapping levels of palliative care development in 198 countries: the situation in 2017 J Pain Symptom Manage 59(4) 794-807 https://doi.org/10.1016/j.jpainsymman.2019.11.009 PMCID: 7105817

36. The Official Gazette (1998) The Prime Minister's Office of the Republic of Turkey Patient Rights Regulation pp 67 [https://www.resmigazete. gov.tr/arsiv/23420.pdf] Date accessed: 18/12/20

37. The Official Gazette (2005) The Presidency of the Republic of Turkey Regulation on Home Care Services Provision [https://www.resmigazete. gov.tr/eskiler/2005/03/20050310-5.htm] Date accessed: 18/12/20

38. Ministry of Health Directive (2010) The Directive on Application of Procedures and Principles of Home Health Services Provided by The Ministry of Health (Ministry of Health Directive) [https://www.memurlar.net/haber/159492/saglik-bakanliginca-sunulan-evde-saglikhizmetlerinin-uygulama-usul-ve-esaslari-hakkinda-yonerge.html] Date accessed: 18/12/20

39. Ministry of Health Directive (2015) The Directive on The Application Procedures and Principles of Palliative Care Services (Ministry of Health Directive) [https://khgmsaglikhizmetleridb.saglik.gov.tr/Eklenti/2817/0/palyatif-bakim-hizmetleri-yonergesipdf.pdf] Date accessed: $18 / 12 / 20$

40. The Official Gazette (2014) The Presidency of the Republic of Turkey. The notification for amending the Social Security Institution Healthcare Implementation [https://resmigazete.gov.tr/fihrist?tarih=2014-12-24] Date accessed: 18/12/20

41. The Official Gazette (2015) The presidency of the republic of Turkey Regulation on Home Care Services Provision by the Ministry of Health and its Affiliates [https://www.resmigazete.gov.tr/eskiler/2015/02/20150227-14.htm] Date accessed: 18/12/20

42. Anatolian Agency (2014) The Morphine Tablet of Turkey was Licensed [https://www.aa.com.tr/tr/saglik/ilk-yerli-morfin-tablet-ruhsataldi/92033] Date accessed: 18/12/20

43. Hacikamiloglu E, Utku ES, and Cukurova Z, et al (2016) Community palliative care in Turkey: a collaborative promoter to a new concept in the Middle East J Public Health Manag Pract 22(1) 81-8 https://doi.org/10.1097/PHH.0000000000000252

44. Utku ES, Hacikamiloglu E, and Gultekin M, et al (2017) Chapter 19: Experience associated with the developing nationwide palliative care services in the community: what can one learn from it for the future? Palliative Care: Perspectives, Practices and Impact on Quality of Life. A Global View ed M Silbermann vol. 1 pp 287-294 (New York: Nova Science Pub Inc)

45. The Official Gazette (2011) The presidency of the republic of Turke Regulatıon on Ege University Palliative Care Research and Application Center [https://www.resmigazete.gov.tr/eskiler/2011/04/20110414-22.htm] Date accessed: 18/12/20

46. Kinay M (2011) Capacity building on new palliative care services J Pediatr Hematol Oncol 33 https://doi.org/10.1097/ MPH.Ob013e31821283e0 PMID: 21448045 
47. Isıkhan V (2017) The place and future of social work in palliative care services in Turkey: state of the art Soc Work Public Health 32(3) 192-201 https://doi.org/10.1080/19371918.2016.1230080

48. Palliative Care Nurses Association [https://www.palhemder.org/hakkimizda] Date accessed: 15/01/21

49. Benli AR and Erbesler ZA (2016) Differences on comprehension and practice in palliative care in Turkey Turk J Fam Pract 20(1) 5-6 https://doi.org/10.15511/tahd.15.21605

50. Alkan A, Özgül S, and Mızrak D, et al (2015) Kanser hastasında ağrı yönetimi. 21st National Cancer Congress (Antalya, 22-26 April 2015)

51. Mutafoğlu K, Çetinayak O, and Güzelöz Çapar Z, et al (2011) Onkoloji doktorları kanserde palyatif bakım koşulları hakkında ne düşünüyorlar? 19th National Cancer Congress (Antalya, 20-24 April 2011)

52. Elcigil A (2011) The current status of palliative care in Turkey: a nurse's perspective J Pediatr Hematol Oncol 33(Suppl. 1) S70-S72 https://doi.org/10.1097/MPH.0b013e318212244a PMID: 21448043

53. Terzioğlu F, Uslu Şahan F, and Boztepe H (2015) Palliative care to the cancer patient: Turkish nurses' perspectives J Palliat Care Med S5 004 https://doi.org/10.4172/2165-7386.1000S5004

54. Akgün Kostak M, and Akan M (2011) Palliative care for children in terminal period Turk J Oncol 26(4) 182-192 https://doi.org/10.5505/ tjoncol.2011.439

55. Elcigil A (2012) Palyatif bakım hemşireliği Gulhane Med J 54 329-334 https://doi.org/10.5455/gulhane.30582

56. Okçin F (2019) Onkoloji palyatif bakım hemşirelerinin mesleki yaşam deneyimlerinin incelenmesi Manisa Celal Bayar Univ J Inst Health Sci 6(4) 234-246

57. Uğur Ö, Mert H, and Bektaş M, et al (2015) Bir üniversite hastanesinde çalışan hemşirelerin palyatif bakım ve uygulama engellerine yönelik algılarının incelenmesi 21st National Cancer Congress (Antalya, 22-26 April 2015)

58. Emuk Y, and Naz I (2017) The current situation of palliative care in Turkey J Cancer Policy 13 33-337 https://doi.org/10.1016/j. $\underline{\text { jсpo.2017.07.001 }}$

59. Eyigor S, and Akdeniz S (2014) Is exercise ignored in palliative cancer patients? World J Clin Oncol 5(3) 554-559 https://doi.org/10.5306/ wjco.v5.i3.554 PMID: 25114869 PMCID: 4127625

60. Eyigor S (2010) Physical activity and rehabilitation programs should be recommended on palliative care for patients with cancer J Palliat Med 13(10) 1183-1184 https://doi.org/10.1089/jpm.2010.0064 PMID: 20942758

61. Keser I, Özdemir K, and Ertürk B, et al (2017) Kanser hastalarına yönelik onkolojik fizyoterapi ve rehabilitasyon ünitesinde sunulan hizmetlerin analizi J Gazi Univ Health Sci Inst 2(1) 18-27

62. Vardar Yağlı N, Şener G, and Arıkan H, et al (2015) Do yoga and aerobic exercise training have impact on functional capacity, fatigue, peripheral muscle strength and quality of life in breast cancer survivors? Integr Cancer Ther 14(2) 125-132 https://doi. org/10.1177/1534735414565699

63. Saruç S (2013) The role of the social worker and social work standards in palliative and end of life care J Soc Soc Work 24(2) 193-207

64. Kafadar D, Ince N, and Akcakaya A, et al (2015) Evaluation of managerial needs for palliative care centers: perspectives of medical directors Asian Pac J Cancer Prev 16(11) 4653-4658 https://doi.org/10.7314/APJCP.2015.16.11.4653 PMID: 26107219

65. Güngör Tavşanlı N, Çeçen D, and Tayhan E, et al (2016) Kanser hastalarına bakım verenlerin hastalara karşı duygu ve tutumları Manisa Celal Bayar Univ J Inst Health Sci 3(4) 470-475

66. YIImaz F, and Atay S (2014) Clinical pain management of nursing students J Hacettepe Univ Fac Nurs 1(2) 32-41 
67. Sahin E, Guvenc G, and Bagcivan G, et al (2017) What are Turkish nursing students thoughts about palliative care? Support Care Cancer 21-266

68. Cetintas I, Akgun Kostak M, and Semerci R, et al (2018) Death anxiety and attitudes toward the principles of dying with dignity of nursing students who practicing in pediatric oncology clinic Support Care Cancer 26(Suppl 2) 39-364

69. Ay F, and Gençtürk N (2013) Midwifery student's opinions related to death, terminal period and palliative care: focus group Florence Nightingale Hemşirelik Derg 21(3) 164-171

70. Yildirim YK, Cicek F, and Uyar M (2008) Knowledge and attitudes of Turkish oncology nurses about cancer pain management Pain Manag Nurs 9(1) 17-25 https://doi.org/10.1016/j.pmn.2007.09.002 PMID: 18313586

71. Akelma H, and Platin B (2018) Sağlık bilimleri gazi yaşargil eğitim araştırma hastanesi sağlık personelinin palyatif bakıma ilişkin görüşleri Palliative Care and Hospice Congress (i̇stanbul, 9-11 March 2018)

72. Dokuyucu A, Ekinci O, and Yılmaz Akyüz E, et al (2018) Hastanemiz sağlık çalışanlarının palyatif bakım bilgi düzeylerinin ölçülmesi Palliative Care and Hospice Congress (İstanbul, 9-11 March 2018)

73. Eyigor S (2013) Fifth-year medical students' knowledge of palliative care and their views on the subject J Palliat Med 16(8) 941-946 https://doi.org/10.1089/jpm.2012.0627 PMID: 23786426

74. Oktay E, Levent M, and Gelincik H, et al (2020) Perspective of Turkish medicine students on cancer, cancer treatments, palliative care, and oncologists (ARES Study): a study of the palliative care working committee of the Turkish Oncology Group (TOG) J Cancer Educ 35(1) 69-75 https://doi.org/10.1007/s13187-018-1441-6

75. Akdeniz Kudubes A, and Bektas M (2020) The effect of web-based pediatric palliative care education on the palliative care knowledge level and practices of nursing students Perspect Psychiatr Care 56(3) 533-540

76. Turgay G, and Kav S (2012) Turkish healthcare professionals' views on palliative care J Palliat Care 28(4) 267-273 https://doi. org/10.1177/082585971202800405

77. Peker L, Celebi N, and Canbay Ö, et al (2008) Doctors' opinions, knowledge and attitudes towards cancer pain management in a university hospital Agri 20(2) 20-30 PMID: 19021007

78. Bağtatılı Aydın H, and Eşer I (2010) Comparison of the pain assessment of the nurses and cancer patients J Ege Univ Nurs Fac 26(1) 11-23

79. Uslu-Sahan F, and Terzioglu F (2017) Nurses' knowledge and practice toward gynecologic oncology palliative care J Palliat Care Med 7(4) 1-6 https://doi.org/10.4172/2165-7386.1000315

80. Polat U, and Karatas T (2018) Nursing students' knowledge of palliative care at a university in Turkey Res Theory Nurs Pract 32(3) 276-295 https://doi.org/10.1891/1541-6577.32.3.276 PMID: 30567839

81. Tanriverdi O, Yavuzsen T, and Akman T, et al (2015) The Perspective of non-oncologist physicians on patients with metastatic cancer and palliative care (ALONE Study): a study of the palliative care working cmmittee of the Turkish oncology group (TOG) $J$ Cancer Educ 30(2) 253-259 https://doi.org/10.1007/s13187-015-0794-3 PMID: 25631655

82. Demirgil M (2019) Ethical Sensitivity of Emergency Service Employees and Their Thoughts About and Knowledge Levels Concerning Palliative Care [Dissertation] (Tokat:Gaziosmanpaşa University)

83. Çakıcı NI (2010) Palliative Care Practice of Physicians and Nurses for the Children with Cancer [Dissertation] (Istanbul: Marmara University)

84. Akyar I, Dionne-Odom JN, and Ozcan M, et al (2019) Needs assessment for Turkish family caregivers of older persons with cancer: first-phase results of adapting an early palliative care model J Palliat Med 22(9) 1065-1074 https://doi.org/10.1089/jpm.2018.0643 PMID: 30969144 PMCID: 7364320 
85. Dincer M, Kahveci K, and Doger C (2018) An examination of factors affecting the length of stay in a palliative care center J Palliat Med 21(1) 11-15 https://doi.org/10.1089/jpm.2017.0147

86. Sarıcam G, Kahvecı K, and Akdogan D (2019) Prevalence of neurological symptoms in palliative care cancer patients: a retrospective study Neurol Asia 24(4) 333-341

87. Tertemiz OF, and Tuyluoglu E (2020) Are signs of burnout and stress in palliative care workers different from other clinic workers? Agri 32(2) 79-84 PMID: 32297959

88. Ben-Arye E, Schiff E, and Mutafoglu K, et al (2015) Integration of complementary medicine in supportive cancer care: survey of healthcare providers' perspectives from 16 countries in the Middle East Support Care Cancer 23(9) 2605-2612 https://doi.org/10.1007/ s00520-015-2619-7 PMID: 25617072

89. Kucukoner M, Bilge Z, and Isikdogan A, et al (2012) Complementary and alternative medicine usage in cancer patients in southeast of Turkey Afr J Tradit Complement Altern Med 10(1) 21-25 https://doi.org/10.4314/ajtcam.v10i1.4 PMID: 24082321 PMCID: 3746353

90. Irmak Z, Tanriverdi O, and Odemis H, et al (2019) Use of complementary and alternative medicine and quality of life of cancer patients who received chemotherapy in Turkey Complement Ther Med 44 143-150 https://doi.org/10.1016/j.ctim.2019.04.008 PMID: 31126547

91. Düzgün G (2020) Effect of Music on Patients with Pain in Palliative Care Service: A Randomized Controlled Study [Dissertation] (Izmir: Ege University)

92. Guzelant A, Goksel T, and Ozkok S, et al (2004) The European Organization for research and treatment of cancer QLQ-C30: an examination into the cultural validity and reliability of the Turkish version of the EORTC QLQ-C30 Eur J Cancer Care 13(2) 135-144 https:// doi.org/10.1111/j.1365-2354.2003.00435.x

93. Soylu C, Babacan T, and Sever AR, et al (2016) Patients' understanding of treatment goals and disease course and their relationship with optimism, hope, and quality of life: a preliminary study among advanced breast cancer outpatients before receiving palliative treatment Support Care Cancer 24(8) 3481-3488 https://doi.org/10.1007/s00520-016-3182-6 PMID: 27003902

94. Usta Yeşilbakan Ö, Özkütük N, and Karadakovan A, et al (2008) Validity and reliability of the edmonton symptom assessment scale in Turkish cancer patients Turk J Cancer 38(2)

95. Süren M Oi, Kaya Z, and Karaman S, et al (2016) Initial experience with delivery of palliative care to terminal cancer patients Turk J Med Sci 46 388-392 https://doi.org/10.3906/sag-1411-38

96. Bülbül Y ÖT, Arınç S, and Özyürek BA, et al (2018) Sleep disturbances in patients with lung cancer in Turkey Tuber Thorax $66297-303$ https://doi.org/10.5578/tt.67689

97. Topkaya O (2019) Palliative care requirements of cancer patients and investigation of knowledge and expectations related to palliative care of the patients and their families Ann Oncol 30(Suppl 5) 822-823 https://doi.org/10.1093/annonc/mdz273.003

98. Bagcivan G, Tosun N, and Komurcu S, et al (2009) Analysis of patient-related barriers in cancer pain management in Turkish patients J Pain Symptom Manage 38(5) 727-737 https://doi.org/10.1016/j.jpainsymman.2009.03.004 PMID: 19692202

99. Yildirim $Y$, Tokem $Y$, and Bozkurt N, et al (2011) Reliability and validity of the Turkish version of the memorial symptom assessment scale in cancer patients Asian Pac J Cancer Prev 12(12) 3389-3396 PMID: 22471486

100. Ozalp GS, Uysal N, and Oguz G, et al (2017) Identification of symptom clusters in cancer patients at palliative care clinic Asia Pac J Oncol Nurs 4(3) 259-264 https://doi.org/10.4103/apjon.apjon_17_17 PMID: 28695173 PMCID: 5473098

101. Sahin ZA, Tan M, and Polat H (2013) Hopelessness, depression and social support with end of life Turkish cancer patients Asian Pac J Cancer Prev 14(5) 2823-2828 https://doi.org/10.7314/APJCP.2013.14.5.2823 PMID: 23803038 
102. Tanriverdi O, Yavuzsen T, and Turhal S, et al (2016) Depression and socio-economical burden are more common in primary caregivers of patients who are not aware of their cancer: TURQUOISE study by the palliative care working committee of the Turkish oncology group (TOG) Eur J Cancer Care (Engl) 25(3) 502-515 https://doi.org/10.1111/ecc.12315

103. Sahin ZA, and Tan M (2012) Loneliness, depression, and social support of patients with cancer and their caregivers Clin J Oncol Nurs 16(2) 145-149 https://doi.org/10.1188/12.CJON.145-149 PMID: 22459523

104. Ciraci Y, Nural N, and Salturk Z (2016) Loneliness of oncology patients at the end of life Support Care Cancer 24(8) 3525-3531 https:// doi.org/10.1007/s00520-016-3159-5 PMID: 27007284

105. Yuceege M, Sanisoglu B, and Firat H, et al (2015) The clinical utility of memorial symptom assessment-short form and condensed memorial symptom assessment scale in Turkish lung cancer patients Clin Respir J 9(2) 221-227 https://doi.org/10.1111/crj.12127 PMID: 25849299

106. Ozcelik H, Cakmak DE, and Fadiloglu C, et al (2015) Determining the satisfaction levels of the family members of patients with advanced-stage cancer Palliat Support Care 13(3) 741-747 https://doi.org/10.1017/S1478951514000534

107. Ozcelik H, Guzel Y, and Sonmez E, et al (2016) Reliability and validity of the Turkish version of the EORTC QLQ-C15-PAL for patients with advanced cancer Palliat Support Care 14(6) 628-634 https://doi.org/10.1017/S1478951516000195 PMID: 27068607

108. Seven M, Sahin E, and Yilmaz S, et al (2016) Palliative care needs of patients with gynecologic cancer J Clin Nurs 25 https://doi. org/10.1111/jocn.13280

109. Alkan A, Guc ZG, and Senler FC, et al (2016) Breast cancer survivors suffer from persistent postmastectomy pain syndrome and posttraumatic stress disorder (ORTHUS study): a study of the palliative care working committee of the Turkish oncology group (TOG) Support Care Cancer 24(9) 3747-3755 https://doi.org/10.1007/s00520-016-3202-6 PMID: 27039206

110. Iyigun E, Tastan S, and Gezginci E, et al (2017) Cross-cultural adaptation and psychometric evaluation of the Turkish version of the cancer behavior inventory-brief version J Pain Symptom Manage 54(6) 929-935 https://doi.org/10.1016/j.jpainsymman.2017.08.006 PMID: 28807698

111. Senel G, Uysal N, and Oguz G, et al (2017) Delirium frequency and risk factors among patients with cancer in palliative care unit $A m$ J Hosp Palliat Care 34(3) 282-286 https://doi.org/10.1177/1049909115624703

112. Bagcivan G, Bredle J, and Bakitas M, et al (2019) Reliability and validity of the Turkish version of the FACIT-PAL quality of life instrument J Pain Symptom Manage 58(2) 297-305 https://doi.org/10.1016/j.jpainsymman.2019.04.020 PMID: 31096004

113. Yildiz Celtek N, Suren M, and Demir O, et al (2019) Karnofsky performance scale validity and reliability of Turkish palliative cancer patients Turk J Med Sci 49(3) 894-898 https://doi.org/10.3906/sag-1810-44 PMID: 31192546 PMCID: 7018389

114. Kocatepe V, Kayikci EE, and Saygili U, et al (2020) The palliative care outcome scale: Turkish validity and reliability study Asia Pac J Oncol Nurs 7(2) 196-202 https://doi.org/10.4103/apjon.apjon_51_19 PMID: 32478138 PMCID: 7233559

115. Dincer M, Torun N, and Aksakal H (2018) Determining nurses' perceptions of patient safety culture in palliative care centres Contemp Nurse 54(3) 246-257 https://doi.org/10.1080/10376178.2018.1492350 PMID: 29966495

116. Ozcelik H, Fadiloglu C, and Karabulut B, et al (2014) Examining the effect of the case management model on patient results in the palliative care of patients with cancer Am J Hosp Palliat Care 31(6) 655-664 https://doi.org/10.1177/1049909113506980

117. Uysal N, Senel G, and Karaca S, et al (2015) Symptoms seen in inpatient palliative care and impact of palliative care unit on symptom control Agri 27(2) 104-110 PMID: 25944137

118. Eskigulek Y, and Kav S (2019) Opinions of palliative care patients and nurses regarding dignified care Ann Oncol 30(Suppl 5) 822-824 https://doi.org/10.1093/annonc/mdz273 
119. Gültaş C, and Yılmaz M (2017) Challenges experienced by and quality of life of relatives of cancer patients requiring palliative care at home Turk J Oncol 32(2) 55-62

120. Cleary J, Silbermann M, and Scholten W, et al (2013) Formulary availability and regulatory barriers to accessibility of opioids for cancer pain in the Middle East: a report from the global opioid policy initiative (GOPI) Ann Oncol 24(Suppl 11) 51-59 https://doi. org/10.1093/annonc/mdt503

121. Silbermann M (2010) Opioids in middle eastern populations Asian Pac J Cancer Prev 11 1-6 PMID: 20590340

122. Vranken MJ, Lisman JA, and Mantel-Teeuwisse AK, et al (2016) Barriers to access to opioid medicines: a review of national legislation and regulations of 11 central and eastern European countries Lancet Oncol 17(1) e13-e22 https://doi.org/10.1016/S14702045(15)00365-4 PMID: 26758755

123. Senel G, Oguz G, and Kocak N, et al (2016) Opioid use and the management of cancer patient pain in palliative care clinic Agri 28(4) 171-176

124. Can H, Pamuk G, and Bilyay Hi, et al (2017) Narcotic analgesic use of hospitalized patients with lung cancer in palliative care service Fam Pract Palliat Care 1(3) 61-64

125. Kurşun YZ, Yıldız F, and Kaymaz Ö, et al (2015) Analgesic step ladder treatment in cancer patients with pain Agri 27(1) 26-34 https:// doi.org/10.5505/agri.2015.08216

126. Orhan ME, Bilgin F, and Ergin A, et al (2008) Pain treatment practice according to the WHO analgesic ladder in cancer patients: eight years experience of a single center Agri 20(4) 38-44

127. Bilen A, Ali A, and Baturay F, et al (2010) Breakthrough pain frequency in cancer patients and the efficiency of oral transmucosal fentanyl citrate Agri 22(3) 103-108 PMID: 20865581

128. Taçyıldız N, Ünal E, and Dinçaslan H, et al (2018) Ankara Üniversitesi Tıp Fakültesi çocuk onkoloji bölümünde 2016-2018 yıllarında izlenen son dönem kanser hastalarında ağrı yönetimi TPOG National Childhood Cancer Congress (Antalya, 2-6 May 2018)

129. Çolak D, Oguz A, and Yazilitas D, et al (2013) The attitudes of cancer patients about morphine usage for pain management Support Care Cancer 21(Suppl 1) S2-301

130. Görgün G, Aslan F, and Ünal Z, et al (2009) Metastatik kanserli hastalarda ağrı değerlendirmesi ve palyasyonu 18th National Cancer Congress (Antalya, 21-26 April 2009)

131. Urlu S, Yücel A, and Yanar A, et al (2009) Onkoloji hastalarında girişimsel ağrı tedavisi 18th National Cancer Congress (Antalya, 21-26 April 2009)

132. Koyuncu İ, and Aksu M (2009) Terminal dönemdeki ağrılı kanser hastalarına uygulanan morfin sülfat infüzyonunun ağrı düzeyine etkisi 18th National Cancer Congress (Antalya, 21-26 April 2009)

133. Centeno C, Clark D, and Lynch T, et al (2007) Facts and indicators on palliative care development in 52 countries of the WHO European region: results of an EAPC Task Force Palliat Med 21(6) 463-471 https://doi.org/10.1177/0269216307081942 PMID: 17846085

134. Mutafoglu K, and Group DEUPCS (2011) A palliative care initiative in Dokuz Eylul University Hospital J Pediatr Hematol Oncol 33(Suppl 1) S73-S76 https://doi.org/10.1097/MPH.0b013e318212245d PMID: 21448044

135. Mojen LK, Rassouli M, and Eshghi P, et al (2017) Palliative care for children with cancer in the Middle East: a comparative study Indian J Palliat Care 23(4) 379-386 https://doi.org/10.4103/IJPC.IJPC_69_17 PMID: 29123342 PMCID: 5661338

136. Arias-Casais N, Garralda E, and Pons JJ, et al (2020) Mapping pediatric palliative care development in the WHO-European region: children living in low-to-middle-income countries are less likely to access it J Pain Symptom Manage 60(4) 746-753 https://doi. org/10.1016/j.jpainsymman.2020.04.028 PMID: 32437945 
137. Koçatakan P (2020) Current status of the palliative care in Turkey R4HC Workshop on Palliative Care in 2020 \& Beyond (Ankara, 27-28 February 2020)

138. Işık O, Kandemir A, and Erişen MA, et al (2016) Evde sağlık hizmeti alan hastaların profili ve sunulan hizmetin değerlendirilmesi Hacettepe Sağlık İdaresi Derg 19(2) 171-186

139. Ozdemir T, Ozdilekcan C, and Goksel F (2019) The contribution of hospital-based home health services in pulmonary diseases: current practice in Turkey Medicine (Baltimore) 98(48) e18032 https://doi.org/10.1097/MD.0000000000018032

140. Göksel F, and Doğan L (2019) Türkiyede gastrointestinal sistem kanseri olan hastalarda evde sağlık hizmetlerinin gelişimi 23rd National Cancer Congress (Antalya, 17-21 April 2019)

141. Benli AR, and Sunay D (2017) A model of collaboration between palliative care unit and home health care services: Karabük Ankara Med J 17(3) 153-150 https://doi.org/10.17098/amj.277493

142. Pilatin B, and Araç E (2018) Diyarbakır ili palyatif bakım biriminde yatan hastaların retrospektif analizi Palliative Care and Hospice Congress (İstanbul, 9-11 March 2018)

143. Toprak SF, and Pilatin B (2018) Sağlık bilimleri unıversitesi Gazi Yaşargil eğitim ve araştırma hastanesi palyatif bakım biriminde yatan hastaların retrospektif analizi Palliative Care and Hospice Congress (İstanbul, 9-11 March 2018)

144. Ekinci O, Keleş Z, and Düzgün Keskin M, et al (2018) Palyatif bakım merkezimizin hasta profili Palliative Care and Hospice Congress (İstanbul, 9-11 March 2018)

145. Sezer M, Üskent N, and Onat H (2010) 2008-2009 yıllarında merkezimizde yatarak tedavi gören hastaların özellikleri TTOK: 3rd Turkish Society of Medical Oncology Congress (Antalya, 24-28 March 2010)

146. Balyılmaz H, Karayağız Muslu G, and et al (2009) Parental views regarding symptoms in children with cancer and recognition of cancer-related fatigue Turk J Oncol 24(3) 122-127

147. Dayanç I, Çakır B, and Moral A, et al (2015) Kemoterapi sonrasında taburcu edilen telefon ile danışmanlık hizmeti almak için arayan hastaların bildirdikleri semptomların ve sorunların analizi 21st National Cancer Congress (Antalya, 22-26 April 2015)

148. Yavuzşen T, Arslan D, and Çehreli R, et al (2011) Ayaktan kemoterapi alan hastalarda semptom sıklığı 19th National Cancer Congress (Antalya, 20-24 April 2011)

149. Topaloğlu N, Çelik Onur S, and Doğan S, et al (2011) Kanser ağrısına sahip hastalarda ağrı kontrolünü etkileyen faktörler 19th National Cancer Congress (Antalya, 20-24 April 2011)

150. Tapar H, Yıldız Çeltek N, and Süren M (2018) Kolon kanserli hastalarda nöropatik ağrı sıklı̆ı Palliative Care and Hospice Congress (İstanbul, 9-11 March 2018)

151. Özsoy Z, Okan I, and Daldal E, et al (2018) Palyatif cerrahi uygulamalarımız: 75 hastanın değerlendirilmesi Palliative Care and Hospice Congress (istanbul, 9-11 March 2018)

152. Kuşçu A, Topkaya Ö, and Yanar A, et al (2014) Asit palyasyonu uygulanan onkoloji hastalarında tedavi ve hemşirelik bakımı TTOK: 5th Turkish Society of Medical Oncology Congress (Antalya, 19-23 March 2014)

153. Bagcivan G, Bakitas M, and Palmore J, et al (2017) Symptom experience of patients with cancer presenting to an academic outpatient palliative / supportive care clinic Support Care Cancer 21-266

154. Yıldız Savran F, and Semerci R, et al (2017) Kanser tanısı ile izlenen çocuklarda semptom kümelemesi 22nd National Cancer Congress (Antalya, 19-23 April 2017)

155. Sögütlü Çetin M, and Kuran Akburak i (2017) İstanbul Üniversitesi Onkoloji Enstitüsü’nde kemoterapi alan hastaların semptomlarının değerlendirilmesi 22nd National Cancer Congress (Antalya, 19-23 April 2017) 
156. Kuşçu A, Topkaya Ö, and Erbay Ç (2015) Malignite tanısı alıp küratif tedavi planı olan hastaların yatış endikasyonları ve hemşirelik bakımı 21st National Cancer Congress (Antalya, 22-26 April 2015)

157. Özçelik H, Güzel Y, and Fadıloğlu Ç, et al (2013) ileri evre kanser hastalarının semptom dağılımları ve etkileyen faktörlerin belirlenmesi 20th National Cancer Congress (Antalya, 19-23 April 2013)

158. Özçelik H, Çakmak DE, and Fadıloğlu Ç, et al (2013) illeri evre kanser hastasinin aile memnuniyet düzeylerinin belirlenmesi 20th National Cancer Congress (Antalya, 19-23 April 2013)

159. Demirkaya M, Özdemir R, and Güler S, et al (2013) Pediatrik onkoloji hastalarının ağrı deneyimlerinin değerlendirilmesi 20th National Cancer Congress (Antalya, 19-23 April 2013)

160. Çakır FB, and Uzuner S (2017) Kanserli çocuk hastalarda bir palyatif bakım olarak nazogastrik tüple beslenme 22nd National Cancer Congress (Antalya, 19-23 April 2017y)

161. Topkaya Ö, Kuşçu A, and Sezer M, et al (2016) Malignite tanısı ıie exitus olan hastaların semptom değerlendirmesı TTOK: 6th Turkish Society of Medical Oncology Congress (Antalya, 23-27 March 2016)

162. Kılıçkap S, Hayran M, and Erman M, et al (2010) Kanser hastalarında yaşam kalitesi ile hastalığın klinikopatolojik özellikleri arasındaki ilişkinin değerlendirilmesi TTOK: 3rd Turkish Society of Medical Oncology Congress (Antalya, 24-28 March 2010)

163. Kılıçkap S, Hayran M, and Yüce D, et al (2012) Kanser hastalarında tanı anındaki yaşam kalitesi genel sağkalımı etkiliyor mu? TTOK: 4th Turkish Society of Medical Oncology Congress (Antalya, 21-25 May 2012)

164. Bagcivan G, Akbayrak N, and Cinar Fl, et al (2011) Evaluation of the relationship between level of nursing care satisfaction and symptom experience due to chemotherapy in cancer patients Support Care Cancer 19(Suppl 2) S67-S370

165. Erol O, Unsar S, and Yacan L, et al (2015) Pain experiences of patients with cancer: a phenomenological study Support Care Cancer 23(Suppl 1) 1-388

166. Koç Z, Kiymaz D, and Saglam Z (2015) Determining the fatigue level and the affecting factors in oncologic patients Support Care Cancer 23(Suppl 1) 1-388

167. Seven M, Akyüz A, and Sever N, et al (2012) Palliative care needs of patients with cancer Support Care Cancer 20(Suppl 1) 1-283

168. Gok Metin Z, Izgu N, and Karadas C, et al (2019) Mindfulness meditation and progressive muscle relaxation for breast cancer patients receiving adjuvant Paclitaxel regimen: a randomized controlled trial Support Care Cancer 1-302

169. Genç F, Köçkar Ç, and Mutlu F, et al (2018) Non-pharmacological methods for the pain management of cancer patients J Educ Res Nurs 15(2) 88

170. Arslan M, Albaş S, and Küçükerdem HS, et al (2016) The evaluation of the effectiveness of palliative pain management in cancer patients with visual analogue scale Fam Pract Palliat Care 1(1) 5-8

171. Avcı D, and Çetinkaya A (2019) The impact of nutritional status on the outcomes of cancer patients such as mortality, survey and length of hospitalization in palliative care Eur Res J 5(2) 375-381

172. Gelin D, and Ulus B (2015) The life quality of the patients receiving chemotherapy in the hospital and the influencing factors ACU Sağlık Bil Derg 6(1) 31-35

173. Usta Yeşilbakan Ö, Durmaz Akyol A, and Çetinkaya Y, et al (2005) Studying the symptoms that are beıng experienced due to treatment by the patients who receive chemotheraphy and their effects on the quality of life J Ege Univ Nurs Fac 21(1) 13-31

174. Çivi S, Kutlu R, and Çelik HH (2011) Depression status and the factors affecting the quality of life in the relatives of the patients with cancer Gulhane Med J 53(4) 248-253 
175. Palalı F, Karaman N, and Şahin S, et al (2018) Çocuk hematoloji-onkoloji kliniğinde yatarak tedavi gören hastalarda ağrının değerlendirilmesi ve yaşam kalitesine etkisi TPOG National Childhood Cancer Congress (Antalya, 2-6 May 2018)

176. Savran F, Semerci R, and Akgün Kostak M, et al (2018) Kanserli çocukların yaşam kaliteleri ile annelerin sağıık bakım memnuniyetleri arasındaki ilişki TPOG National Childhood Cancer Congress (Antalya, 2-6 May 2018)

177. Kutlutürkan S, Sözeri E, and Bay F (2013) Kanser hastalarının kemoterapiye bağlı gelişen sorunlara ilişkin yaptıkları uygulamalar ve yaşam kalitesine etkisi 20th National Cancer Congress (Antalya, 19-23 April 2013)

178. Karciga F, and Oflaz F (2018) Metastatik kanserli çocukların anne ve babalarının çocuklarının yaşam kalitesi algılarının ve anksiyete düzeylerinin incelenmesi Palliative Care and Hospice Congress (İstanbul, 9-11 March 2018)

179. Eren MF, Börklü Doğan Ö and Şimşek E, et al (2016) Palyatif destek gerektiren kanser hastalarında evde bakım ve değerlendirmenin yatış sıklığı ve bakım kalitesine etkisi TTOK: 6th Turkish Society of Medical Oncology Congress (Antalya, 23-27 March 2016)

180. Yavas C, Zorlu F and Ozyigit G, et al (2011) Quality of life in patients with malignant glioma: a prospective study in Turkish population Support Care Cancer 19(Suppl 2) S67-S370

181. Koç Z, Kiymaz D and Saglam Z (2013) The determination of life quality and satisfaction and pain perception in cancer patients Support Care Cancer 21(Suppl 1) S2-S301

182. Bilgin Ö, Özdemir D and Saçkan F, et al (2020) Evaluation of care dependence levels of inpatients in nephrology and oncology J Gen Health Sci 2(1) 14-23

183. Tosun B, Aslan Ö and Yaranoğlu C et al (2017) Palyatif bakım alan akciğer kanserli hastalarının beslenme deneyimleri ve bakım vericilerinin yaşadıkları güçlükler 22nd National Cancer Congress (Antalya, 19-23 April 2017)

184. Almaca B, Gökçen S and Kılınç M, et al (2019) Palyatif destek amacıyla onkoloji servisine yatırılan kanser hastalarında enteral ve parenteral beslenmenin klinik sonuçlara etkisi 23rd National Cancer Congress (Antalya, 17-21 April 2019)

185. Özdemir Ü and Taşçı S (2017) Kanserli yaşlı bireylerde akupresin kanserle ilişkili yorgunluğa etkisi 22nd National Cancer Congress (Antalya, 19-23 April 2017)

186. Şen D, Yüntem A and Akbal E, et al (2017) Refleksoloji uygulamasının ağrı, anksiyete ve bulantı üzerine etkisi 22nd National Cancer Congress (Antalya, 19-23 April 2017)

187. Yildiz A, Ozdemir O and Atik A, et al (2015) The effect of individual physiotherapy and rehabilitation training program on lymphedema in patients with mastectomy Support Care Cancer23(Suppl 1) 1-388

188. Kırsever E, Kızıltan HŞ and Yilmaz R, et al (2018) Metastatik kanser hastalarında palyatif biyorezonans tedavisi Palliative Care and Hospice Congress (Istanbul, 9-11 March 2018)

189. Yıldırım S and Gürkan A (2007) The influence of music on anxiety and the side effects of chemotherapy Anatolian J Psychiatry 837 -35

190. Çınkır HY and Kahraman A (2017) Retrospective analysis of patients followed at Van Training and Research Hospital palliative care unit Eastern J Med 22 172-175 https://doi.org/10.5505/ejm.2017.92005

191. Ozcelik H, Fadiloglu C and Karabulut B, et al (2014) Case management based multidisciplinary care protocol in the palliative care of cancer patients Agri 26(2) 47-56 https://doi.org/10.5505/agri.2014.93585

192. Erkal KH, Yüce $Y$ and Geyik FD, et al (2018) Üçüncü basamak yoğun bakım ünitesinde tedavi edilen palyatif bakım hastalarının değerlendirilmesi Palliative Care and Hospice Congress (Istanbul, 9-11 March 2018)

193. Karaoren G, Akbas S and Ocak Serin S, et al (2016) Hospice units as a requirement for terminal stage patients in need of intensive care in Turkey Int J Clin Exp Med 9 14907-14912 
194. Tanriverdi O, Beydilli $\mathrm{H}$ and Yildirim B, et al (2014) Single center experience on causes of cancer patients visiting the emergency department in southwest Turkey Asian Pac J Cancer Prev 15(2) 687-690 https://doi.org/10.7314/APJCP.2014.15.2.687 PMID: 24568479

195. Yildirim B and Tanriverdi $O$ (2014) Evaluation of cancer patients admitted to the emergency department within one month before death in Turkey: what are the problems needing attention? Asian Pac J Cancer Prev 15(1) 349-353 https://doi.org/10.7314/ APJCP.2014.15.1.349 PMID: 24528055

196. Sezgin Goksu S, Gunduz S and Unal D, et al (2014) Use of chemotherapy at the end of life in Turkey BMC Palliat Care 13(1) 51 https:// doi.org/10.1186/1472-684X-13-51 PMID: 25435808 PMCID: 4247666

197. Kömürcü Ş, Çay Şenler F and Özyılkan Ö, et al (2012) Klinikte ölen terminal dönem kanserli hastalarda son iki hafta içinde yapılan tetkik ve tedaviler TTOK:4th Turkish Society of Medical Oncology Congress (Antalya, 21-25 March 2012)

198. Kütük B, Topkaya Ö and Virdil B, et al (2012) Son dönem hastalarda palyatif kemoterapi TTOK: 4th Turkish Society of Medical Oncology Congress (Antalya, 21-25 March 2012)

199. Kart L, Akkoyunlu ME and Akkoyunlu Y, et al (2011) Evaluation of end stage patient in intensive care unit Selcuk Med J 27(3) 146-148

200. Üçgül Çavuşoğlu E, Akkurt M and Kömürcü Ş, et al (2007) Klinikte Ölen Terminal Dönem Kanserli Hastalarda Son İki Hafta Içinde Yapılan Tetkik ve Tedavilerin Retrospektif Analizi 17th National Cancer Congress (Antalya, 19-23 April 2007)

201. Doruk H, Çay Şenler F and Akbulut H, et al (2007) Hastanede Yatan Terminal Dönemdeki Kanser Hastalarına Uygulanan Tibbi Yaklaşımlar ve Destek Tedavilerinin Değerlendirilmesi 17th National Cancer Congress (Antalya, 19-23 April 2007)

202. Bulbul Y, Ozlu T and Arinc S, et al (2017) Assessment of palliative care in lung cancer in Turkey Med Princ Pract 26(1) 50-56 https://doi. org/10.1159/000452801 PMCID: 5588338

203. Kara T (2017) Opinions of Relatives of Patients with Terminal Cancer About Palliative Care [Dissertation] (Istanbul: Marmara University)

204. Metin S (2018) Relationship Between the Health Literacy Level of Palliative Care Service Patient Companions and Patient Care Results and Survival Status of the Patients [Dissertation] (Bursa: Bursa Yüksek İhtisas Education and Research Hospital)

205. Erdem E (2020) The Effects of Early Palliative Care on Quality of Life [Dissertation] (İzmir: Tepecik Education and Research Hospital)

206. Dagli O, Tasdemir E and Ulutasdemir N (2020) Palliative care infections and antibiotic cost: a vicious circle Aging Male 23(2) 98-105 https://doi.org/10.1080/13685538.2019.1575353

207. Saygılı M and Çelk Y (2019) An evaluation of the cost-effectiveness of the different palliative care models available to cancer patients in Turkey Eur J Cancer Care 28 https://doi.org/10.1111/ecc.13110

208. Aygencel $G$ and Türkoğlu M (2014) General characteristics and costs of terminal-stage patients in a medical intensive care unit $J$ Turk Soc Intens Care 5 1-4

209. Çalışkan AN (2019) Cost Analysis of Palliative Care Centers: a Case of Public Hospital [Dissertation] (Muğla: Sıtkı Koçman University)

210. Gürel Yavuzdemir H (2019) Evaluation of a Palliative Care Center Sample with Inpatient Features, User Satisfaction, Quality of Care Service and Cost Aspects [Dissertation] (Zonguldak: Bülent Ecevit University)

211. Akyüz S (2015) Kanser hastalarına uygulanacak palyatif bakım uygulamalarına ilişkin bir araştırma 21st National Cancer Congress (AntaIya, 22-26 April 2015)

212. Saygili $M$ and Celik $Y$ (2020) An evaluation of palliative care service effect in patients with cancer diagnosis: comparison in terms of the symptom level and care satisfaction Agri 32(2) 61-71 PMID: 32297968

213. Kahveci K and Gokcinar D (2014) Knowledge about palliative care in the families of patients Acta Medica Mediterr 30 1369-1373 
214. Topkaya Ö and Yürügen B (2019) Kanser hastalarının palyatif bakım gereksinimlerỉ ile hasta ve ailelerinin palyatif bakıma ilişkin bilgi ve beklentilerinin lincelenmesi 23rd National Cancer Congress (Antalya, 17-21 April 2019)

215. Doruk H, Çay Şenler F and İçli F (2007) Terminal dönemdeki kanser hastaları ve yakınlarının hastanede uygulanan tıbbi yaklaşımlar ve tedavilerle ilgili görüşleri 17th National Cancer Congress (Antalya, 19-23 April 2007)

216. Karabuğa Yakar H and Pınar R (2013) Evaluation of quality of life among family caregivers of patients with cancer Hemşirelikte Araştırma Geliştirme Derg 15(2) 1-16

217. Oğuz N, Miles S and Büken N, et al (2003) End-of-life care in Turkey Camb Q Healthc Ethics 12 279-284 https://doi.org/10.1017/ S0963180103123109

218. Zeybek Ünsal Ç and Büken N (2017) Comparison of palliative care in Turkey and Europe from ethical and legal perspective with country examples JARSS Anestezi Derg 25 44-51

219. Sert G and Guven T (2013) Examining the ethico-legal aspects of the right to refuse treatment in Turkey J Med Ethics 39(10) 632-635 https://doi.org/10.1136/medethics-2011-100408 PMID: 23596316

220. Baykara N, Utku T and Alparslan V, et al (2020) Factors affecting the attitudes and opinions of ICU physicians regarding end-of-life decisions for their patients and themselves: a survey study from Turkey PLoS One 15(5) e0232743 https://doi.org/10.1371/journal. pone.0232743 PMID: $\underline{32433670}$ PMCID: $\underline{7239490}$

221. Guclu YA, Can H and Atsiz Sezik $\mathrm{H}$ et al (2018) Assessment of the signs of anxiety and depression in relatives giving care to cancer patients hospitalized in the palliative care service Fam Pract Palliat Care 3(2) 98-101

222. Avcı D (2018) Are the nutritional Nrs-2002 scores of cancer patients at the palliative care center related to inflammation? Bozok Med J 8(3) 71-75

223. Babaoğlu E and Öz F (2003) The relationship between psychological and social problems of the spouses who cared for the terminal cancer patients Hemşirelikte Araştırma Geliştirme Derg 2 24-33

224. Çulha Ateşçi F, Kalkan Oğuzhanoğlu N and Baltalarlı B, et al (2003) Psychiatric disorders in cancer patients and associated factors Turk J Psychiatry 14(2) 145-152

225. Düzgün G, Uzun M and Topaloğlu Ö, et al (2016) Comparison of the mourning process of relatives of patients who received internal medicine intensive care and palliative care FNG Demiroğlu Bilim Tıp Derg 2(4) 250-255 https://doi.org/10.5606/fng.btd.2016.045

226. Çırpan Kantarcıoğlu A, Sevinir B and Demirkaya M, et al (2018) Kanser tanısı alan ergenlerin hastalık algılarının değerlendirilmesi TPOG National Childhood Cancer Congress (Antalya, 2-6, May 2018)

227. Abca Yılmazer M and Okyayüz Ü (2013) Palyatif radyoterapi alan kemik metastazlı hastalarda bilgilendirme odaklı ağrı ve depresyon değerlendirmesi 20th National Cancer Congress (Antalya, 19-23 April 2013)

228. Aslan Ö and Akyol M (2010) Hope among family caregivers of cancer patients Support Care Cancer 18(Suppl 3) 77-220

229. Yetisen AY, Arslan D and Yavuzsen T, et al (2011) Scoring anxiety, depression and quality of life in colorectal cancer patients and the effect of patient education on these parameters Support Care Cancer 19(Suppl 2) S67-S370

230. Çıracı Y and Nural N (2015) Loneliness of cancer patients at end of life Support Care Cancer 23(Suppl 1) 1-388

231. Çıracı $Y$ and Nural N (2015) A study of emotional status of cancer patients at end of life Support Care Cancer 23(Suppl 1) 1-388

232. Koç Z, Kiymaz D and Saglam Z (2015) Determining the loneliness and perceived social support levels in oncologic patients Support Care Cancer 23(Suppl 1) 
233. Altınışık M, Kocabıyık B and Arıkan F, et al (2019) Kanser hastalarına bakım verenlerin destekleyici bakım gereksinimleri ve umut düzeyleri 23rd National Cancer Congress (Antalya, 17-21 April 2019)

234. Eskigülek Y and Kav S (2019) Opinions of palliatıve care patients and nurses regarding dignified care Support Care Cancer 1-302

235. Zengin L and Büyükbayram Z (2019) Determining satisfaction levels of cancer patients who receive treatment in the palliative care J Tradit Complem Med 2(1) 17-24 https://doi.org/10.5336/jtracom.2018-63748

236. Dokuyucu A, Ekinci $O$ and Yılmaz Akyüz E, et al (2018) Palyatif bakım merkezimizde hemşirelik hizmetleri memnuniyetinin değerlendirilmesi Palliative Care and Hospice Congress (İstanbul, 9-11 March 2018)

237. Okcin F, Ogce F and Zengin Y, et al (2011) Study of nursıng care satisfaction of patients receiving chemotherapy Support Care Cancer 19(Suppl 2) S67-S370

238. Turkoglu N and Kilic D (2012) Effects of care burdens of caregivers of cancer patients on their quality of life Asian Pac J Cancer Prev 13(8) 4141-4145 https://doi.org/10.7314/APJCP.2012.13.8.4141 PMID: 23098532

239. Koç Z, Sağlam Z and Çınarlı T (2016) Determination of factors affecting the care taking load of care takers for Individuals diagnosed with cancer J Samsun Health Sci 1(1) 99-116

240. Tunçel Yi, Kaya M and Kuru RN, et al (2014) Nurses' burnout in oncology hospital critical care unit J Turk Soc Intens Care 12 57-62

241. Uzelli Yılmaz D, Akın Korhan E and Khorshid L (2017) Evulation of nursing care quality in a palliative care clinic Int J Clin Exp Med 14(3) 2968-2980

242. Kurt S, Ünsar S and Erol Ö (2020) Evaluation of quality of life of caregivers for patients with cancer Süleyman Demirel Univers J Health Sci 11(1) 43-48

243. Akyar I, Korkmaz F and Atakul E (2017) Caregiver outcomes of geriatric oncology patients Mersin Univers J Health Sci 10(3) 158-167

244. Kardaş Özdemir F, Akgün Şahin F and Küçük D (2009) Determination of burden cares for mothers having children with cancer N J Med 26 153-158

245. Yılmaz Karabulutlu E, Akyıl R and Karaman S, et al (2013) Investigation of sleep quality and psychological problems in cancer caregivers Turk J Oncol 28(1) 1-9 https://doi.org/10.5505/tjoncol.2013.807

246. Şener A, Aydoğan $A$ and Koç Z (2018) Palyatif bakım ünitesinde yatan hastaların bakımından sorumlu hasta yakınlarının bakım yükleri ile yaşam doyumlarının belirlenmesi Palliative Care and Hospice Congress (İstanbul, 9-11 March 2018)

247. Ozcelik H, Usta Yesilbalkan O and Fadiloglu C, et al (2011) The relationshıp between caregiving burden and social support in caregivers of patient with cancer Support Care Cancer 19(Suppl 2) S67-S370

248. Koku F (2015) Terminal dönemde hasta bakımına yönelik hemşirelik tutumları 21st National Cancer Congress (Antalya, 22-26 April 2015)

249. Kuşçu A, Topkaya Ö and Yanar A, et al (2015) Yaşam sonu bakımda değerlendirme 21st National Cancer Congress (Antalya, 22-26 April 2015)

250. Özyalçın D and Çevik B (2019) Kanser Hastaları, Yakınları ve Hemşirelerin Ölüme İlişsin Tutumu ve İyi Ölüme İlişkin Görüşleri 23rd National Cancer Congress (Antalya, 17-21 April 2019)

251. Köse F (2019) Palliative sedation in terminal term cancer patients 23rd National Cancer Congress (Antalya, 17-21 April 2019)

252. Bar-Sela G, Schultz MJ and Elshamy K, et al (2019) Training for awareness of one's own spirituality: a key factor in overcoming barriers to the provision of spiritual care to advanced cancer patients by doctors and nurses Palliat Support Care 17(3) 345-352 https://doi. org/10.1017/S147895151800055X 
253. Temelli G and Cerit B (2019) Perceptions of palliative care nurses related to death and palliative care practices Omega (Westport) 30222819890457 https://doi.org/10.1177/0030222819890457

254. Ozveren $\mathrm{H}$ and Kirca K (2019) Influence of palliative care training on last-year nursing department students' perception on regarding spirituality and spiritual care: a single-group pretest-posttest intervention study J Relig Health 58(3) 860-869 https://doi.org/10.1007/ s10943-018-0701-4

255. Okan I, Suren M and Onder Y, et al (2019) An evaluation of the mourning tradition, the 'First Feast', in the context of palliative care: the possibility of incorporating cultural rituals into palliative care Palliat Support Care 17(4) 453-458 https://doi.org/10.1017/ S1478951518000767 PMID: 30628562

256. Akbulut Şahin E (2019) Hasta yakını olmanın getirdiği güçlükler ve dini başa çıkma (Palyatif bakım servisi onkoloji hasta yakınları) [Dissertation] (Izmir: İzmir Katip Çelebi University)

257. Gemalmaz A and Avşar G (2015) Cancer diagnosis and after experiences: a qualitative study J Educ Res Nurs 12(2) 93-98

258. Ozdemir F, Dogan S and Timucin Atayoglu A (2020) Psychosocial problems of family caregivers of palliative care patients and their spiritual coping styles Perspect Psychiatr Care 56(3) 636-641 PMID: 32017126

259. Demirci H and Metin T (2019) Effect of health literacy of caregivers on survival rates of patients under palliative care Scand J Caring

260. Ozmen V, Dagoglu N and Dede I, et al (2016) Turkish Ministry of Health, 2(nd) Turkish Medical General Assembly Clinical Oncology Study Group report J Breast Health 12(1) 9-17 https://doi.org/10.5152/tjbh.2015.2869 PMID: 28331725 PMCID: 5351437

261. World Health Organization (2020) Non-communicable diseases progress monitor 2020 [https://www.who.int/publications/i/item/ ncd-progress-monitor-2020] Date accessed: 18/12/20

262. Turkish Statistical Association (2019) Mortality and cause specific mortality statistics [https://data.tuik.gov.tr/Bulten/Index?p=Olumve-Olum-Nedeni-Istatistikleri-2019-33710] Date accessed: 18/11/20

263. Carrasco JM, Lynch TJ and Garralda E, et al (2015) Palliative care medical education in European universities: a descriptive study and numerical scoring system proposal for assessing educational development Pain Symptom Manage 50(4) 516-523 https://doi. org/10.1016/j.jpainsymman.2015.04.019

264. Kamal AH, Bausewein C and Casarett DJ, et al (2020) Standards, guidelines, and quality measures for successful specialty palliative care integration into oncology: current approaches and future directions J Clin Oncol 38(9) 987-994 https://doi.org/10.1200/ JCO.18.02440 PMID: 32023165 PMCID: 7082154

265. Sedhom R, Gupta A and Von Roenn J, et al (2020) The case for focused palliative care education in oncology training J Clin Oncol 38(21) 2366-2368 https://doi.org/10.1200/JCO.20.00236 PMID: 32271674 PMCID: 8205264

266. Akyar i (2016) Palliative and Supportive care in Turkey: literature review and current status of research 27th Sigma International Nursing Research Congress (Cape Town, 13 July 2016)

267. Özsoy Z (2018) 2000 - 2016 Sürecindeki palyatif bakım yayınlarının bibliyometrik analizi Palliative Care and Hospice Congress (İstanbul, 9-11 March 2018)

268. Cleary J, Radbruch $L$ and Torode J, et al (2013) Next steps in access and availability of opioids for the treatment of cancer pain: reaching the tipping point? Ann Oncol 24(Suppl 11) 60-64 https://doi.org/10.1093/annonc/mdt504

269. International Narcotics Control Board Availability of narcotic drugs for medical use [https://www.incb.org/incb/en/narcotic-drugs/ Availability/availability.html] Date accessed: 18/12/20

270. Ferrell BR, Chung V and Koczywas M, et al (2020) Dissemination and implementation of palliative care in oncology J Clin Oncol 38(9) 995-1001 https://doi.org/10.1200/JCO.18.01766 PMID: 32023151 PMCID: 7082157 
271. Yildiz P, Tanriover MD and Unal S (2020) Turkish Society of Internal Medicine choosing wisely project Eur J Intern Med 76 125-126 https://doi.org/10.1016/j.ejim.2020.03.001 PMID: 32156494

272. Currow DC, Agar MR and Phillips JL (2020) Role of hospice care at the end of life for people with cancer J Clin Oncol 38(9) 937-943 https://doi.org/10.1200/JCO.18.02235 PMID: 32023154

273. Boufkhed S, Harding R and Kutluk T, et al (2020) What is the preparedness and capacity of palliative care services in Middle-Eastern and North African countries to respond to COVID-19? A rapid survey J Pain Symptom Manage e13-e50 PMID: 33227380 PMCID: 7679234

274. Kutluk MT, Ahmed F and Kirazlı M, et al (2021) The effect of the COVID-19 pandemic on paediatric cancer care: lessons learnt from a major paediatric oncology department in Turkey Ecancermedicalscience 151172 https://doi.org/10.3332/ecancer.2021.1172 PMID: 33680086 PMCID: $\underline{7929778}$

275. Radbruch L, De Lima L and Knaul F, et al (2020) Redefining palliative care-a new consensus-based definition J Pain Symptom Manage 60(4) 754-764 https://doi.org/10.1016/j.jpainsymman.2020.04.027 PMID: 32387576 PMCID: 8096724

276. Al-Shahri M (2002) The future of palliative care in the Islamic world West J Med 176(1) 60-61 https://doi.org/10.1136/ewjm.176.1.60 PMID: 11788543 PMCID: 1071657

277. Ertaş IE, Sehirali S and Ozsezgin Ocek S, et al (2014) The effectiveness of subcutaneously implanted epidural ports for relief of severe pain in patients with advanced-stage gynecological cancer: a prospective study Agri 26(1) 8-14 https://doi.org/10.5505/ agri.2014.14227

278. Büken N (2017) Physician-patient communication during the clinical ethical decision-making process in palliative care in Turkey Anestezi Derg 25 3-14

279. Walker DK, Edwards RL and Bagcivan G, et al (2017) Cancer and palliative care in the United States, Turkey, and Malawi: developing global collaborations Asia Pac J Oncol Nurs 4(3) 209-219 https://doi.org/10.4103/apjon.apjon_31_17 PMID: 28695167 PMCID: 5473092

280. Müller-Schwefe GH, Wimmer AM and Dejonckheere J, et al (2014) Patients' and physicians' perspectives on opioid therapy for chronic cancer and musculoskeletal pain in Germany, Italy, and Turkey: PAin RESearch (PARES) survey Curr Med Res Opin 30(3) 339-347 https://doi.org/10.1185/03007995.2013.861349

281. Akyar I, Dionne-Odom JN and Yang GM, et al (2018) Translating a US early palliative care model for Turkey and Singapore Asia Pac J Oncol Nurs 5(1) 33-39 PMID: 29379831 PMCID: 5763436

282. Isikhan V (2010) Coping with stress in patients with advanced cancer Asian Pac J Cancer Prev 11(Suppl 1) 81-92 PMID: 20590356

283. Bar-Sela G, Schultz MJ and Elshamy K, et al (2019) Human development index and its association with staff spiritual care provision: a Middle Eastern oncology study Support Care Cancer 27(9) 3601-3610 https://doi.org/10.1007/s00520-019-04733-0 PMID: 30895381

284. Yalcin S, Gumus M and Oksuzoglu B, et al (2019) Nutritional aspect of cancer care in medical oncology patients Clin Ther 41(11) 2382-2396 https://doi.org/10.1016/j.clinthera.2019.09.006 PMID: 31699437

285. Tekin N (2011) An example of support program to elderly patients and elderly relatives during the terminal period in a developed model of residential home and geriatric care center Turk J Geriatri 14(3) 273-275

286. Yildirim YK, Fadiloğlu C and Uyar M (2006) Palyatif kanser bakımında tamamlayıcı tedaviler [Complementary therapies in palliative cancer care] Agri 18(1) 26-32 PMID: 16783665

287. Çavdar I (2011) Care of the cancer patient in the terminal period Türk Onkol Derg 26(3) 142-147 
288. Kabalak AA (2014) Palliative care in Turkey; 2014, current developments, requirements Anestezi Derg 22(3) 121-123

289. Demir M (2016) Palliative care ethics Yoğun Bakım Derg 7 62-66 https://doi.org/10.5152/dcbybd.2016.1202

290. Isikhan V (2008) Choices of death place in terminal stage cancer patients Türk Onkol Derg 23(1) 34-44

291. Aydoğan F and Uygun K (2011) Kanser hastalarında palyatif tedaviler Klinik Gelişim Derg 4-9

292. Sarıhan E, Kadıoğlu E and Artıran İğde F (2012) Kanser ağrısı, tedavi prensipleri ve Dünya Sağlık Örgütü ağrı basamak tedavisi Nobel Med 8(1) 5-15

293. İnci F and Öz F (2012) Palliative care and death anxiety Currr Approaches Psychiatry 4(2) 178-197

294. Uslu Şahan F and Terzioğlu F (2015) Palliative care education and organization in the world and Turkey Cumhuriyet Nurs J 4(2) 81-90

295. Madenoğlu Kıvanç M (2017) Palliative care services in Turkey J Health Pro 4(2) 132-135

296. Guven DC, Aktepe OH and Berk Z, et al (2019) Embedded outpatient palliative care service within the oncology clinic: preliminary experience in Hacettepe Oncology Hospital Ann Oncol 30(5) V666 https://doi.org/10.1093/annonc/mdz261.017

297. Alkan A, Yaşar A and Güç ZG, et al (2019) Worse patient-physician relationship is associated with more fear of cancer recurrence (Deimos Study): a study of the Palliative Care Working Committee of the Turkish Oncology Group (TOG) Ann Oncol 30(Suppl 5) 667-670 https://doi.org/10.1093/annonc/mdz262.001

298. Gültaş C and Yılmaz M (2015) Palyatif bakım gereksinimi olan kanserli hasta yakınlarının evde bakımda yaşadığı güçlükler ve yaşam kalitesinin belirlenmesi 21st National Cancer Congress (Antalya, 22-26 April 2015)

299. Bozkurt M (2018) Destek tedavi ve hospise yönlendirilen ileri evre mide adenokanseri hastalarının genel sağkalımı Palliative Care and Hospice Congress (İstanbul, 9-11 March 2018)

300. Çakır FB, Uzuner S and Daşkaya H, et al (2018) Kanserli çocuklarda serviste invasiv işlemler için uygulanan derin sedasyonun hastalar ve ebeveynler için oluşturduğu rahatlık Palliative Care and Hospice Congress (İstanbul, 9-11 March 2018)

301. Yavas C, Zorlu F and Ozyigit G, et al (2011) Prospective asessment of quality of life in adult patients treated for low grade glioma Support Care Cancer 19(Suppl 2) S67-S370

302. Tanriverdi O, Yavuzsen T and Akman T, et al (2015) The perspective of non-oncologist physicians on patients with metastatic cancer and palliative care (ALONE Study): a study of the palliative care working committee of the Turkish Oncology Group (TOG) Support Care Cancer 23(Suppl 1) 1-388

303. Özkan S (2012) Self-care and end-of-life care in cancer patients and carers Support Care Cancer 20(Suppl 1) 1-283

304. Cakir FB and Kaygusuz SB (2016) Nasogastric tube feeding in children with cancer as a part of palliative care Pediatr Blood Cancer 63(Suppl 3) S5-S321

305. Bagcivan G, Tosun N and Kömürcü S, et al (2009) Analysis of the patient-related barriers in cancer pain management in Turkish patients Support Care Cancer 17 857-1039

306. Tanrıverdi Ö and Yıldırım B (2014) Ölümlerinden bir ay önce acil servise başvuran ve acil servise başvurmayan son dönem kanser hastalarının irdelenmesi TTOK: 5th Turkish Society of Medical Oncology Congress (Antalya, 19-23 March 2014)

307. Demir F and Yılmaz M (2015) Onkoloji hasta ve hasta yakınlarının evde bakım hizmetlerinden beklentileri 21st National Cancer Congress (Antalya, 22-26 April 2015)

308. Aktaş S, Kuşçu A and İnce A (2009) Kolanjiosarkom'lu bir olguda palyatif bakım uygulamaları 18th National Cancer Congress (Antalya, 21-26 April 2009) 
309. Tiryaki N, Sarıtaş B and Yüntem A, et al (2009) Akciğer kanserli bir olguda, palyatif bakımda hemşirenin rolü 18th National Cancer Congress (Antalya, 21-26 April 2009)

310. Demiral A (2009) Desmoplastik round cell tümörlü bir olguda palyatif bakım uygulamaları ve hemşirelik bakımı 18th National Cancer Congress (Antalya, 21-26 April 2009)

311. Arias-Casais N, Garralda E and Rhee JY, et al (2019) EAPC Atlas of Palliative Care in Europe 2019 (Vilvoorde: EAPC Press)

312. Temelli G (2018) Perceptions of Palliative Care Nurses Related to Death and Palliative Care Practices [Dissertation] (Bolu: İzet Baysal University)

313. Topkaya Ö (2018) Palliative Care Requirements of Cancer Patients and Investigation of Knowledge and Expectations Related to Palliative Care of the Patients and Their Families [Dissertation] (Istanbul: İstanbul Okan University)

314. YIlmaz A (2015) Frequency of Symptomatic Manifestations in Cancer Patients in Palliative Care Unit and the Place of Palliative Symptom Treatment in Symptom Management [Dissertation] (Izmir: İzmir Katip Çelebi University, İzmir Atatürk Training and Research Hospital)

315. Arkın S (2017) Investigation of Anxiety Depression and Social Support Levels in Caregivers of Palliative Patients [Dissertation] (Izmir: İzmir Tepecik Training and Research Hospital)

316. Sağlam Z (2020) Needs of Family Members Caring for Palliative Patients in the Care and Treatment Processes [Dissertation] (Samsun: Ondokuz Mayıs University)

317. Taş M (2020) Evaluation of Nutritional Treatment Approach Results in Palliative Care Patients with Malnutrition [Dissertation] (Kırıkkale: Kırıkkale University)

318. Tanıl E (2020) The Perceptions and Expectations of Pallative Period Oncology Patients About Bad News and Their Attitudes to Death [Dissertation] (Istanbul: Istanbul University)

319. Ardıç S (2020) An Investigation of Self-Compassion Levels of the Relatives of Palliative Stage Oncology Patients in Terms of Psychological Resilience and Quality of Life [Dissertation] (Istanbul: Istanbul University)

320. Duman Ö (2020) The Effect of Care Transmitter Load of Patient Relationships' Views on Paliative Care [Dissertation] (Samsun: Ondokuz Mayıs University)

321. Damak N (2020) Nurses' Perceptions Of Good Death and Levels of Knowledge About Palliative Care [Dissertation] (Istanbul: Biruni University)

322. Karakaya C (2020) Evaluation of Quality of Life Among Caregivers of Palliative Care Patients: Karabük Case [Dissertation] (Ankara: Hacettepe University)

323. Kurtgöz A (2019) Effects of Nursing Care on the Spiritual Well-Being and Hopefulness in Relatives of Palliative Care Patients [Dissertation] (Samsun: Ondokuz Mayıs University)

324. Tarakçı F (2019) Retrospective Evaluation of Term of Hospitalization and Discharge Status of Patients in the Palliative Care Service of a Third Step Hospital [Dissertation] (Izmir: İzmir Tepecik Training and Research Hospital)

325. Çelik A (2019) The Effect of Bright White Light Application on Fatigue Levels and Sleep Quality in Cancer Patients Receiving Palliative Care [Dissertation] (ízmir: Ege University)

326. Özhan E (2019) Evaluation of Psycho-Social Situations of Relatives of Cancer Patients: a Case of Palliative Care Center of Eyüpsultan State Hospital [Dissertation] (Sakarya: Sakarya University)

327. Adanır A (2019) Determination of Compassion Fatigue and Coping Styles with Stress of Nurses Working at Oncology and Palliative Care Units [Dissertation] (ízmir: Dokuz Eylül University)

328. Balcıoğlu i (2019) Investigation of the Relationship Between Nutrition, Infection, and Hospitalisation Time During Palliative Care [Dissertation] (Kütahya: Kütahya Health Sciences University) 
329. Altay M (2019) The Effect of Palliative Care Education on Nurses' Knowledge Levels for Nurses Caring for Oncology Patients [Dissertation] (Istanbul: Koç University)

330. Uslu Şahan F (2018) Effect of Interprofessional Simulation Training on Bringing Palliative Care Competencies to Gynecologic Oncology [Dissertation] (Ankara: Hacettepe University)

331. Kaya H (2018) Consultation of Patients in Palliative Care Service for 1 Year [Dissertation] (Adıyaman: Adıyaman University)

332. Eskigülek Y (2018) Opinions of Palliative Care Patients and Nurses Regarding Dignified Care [Dissertation] (Ankara: Başkent University)

333. Güçlü Y (2018) The Effect of Nutritional Status and Muscle Strength on Survival of the Patients Treated in Palliative Care Units [Dissertation] (Bursa: Bursa Yüksek İhtisas Eğitim ve Araştırma Hastanesi)

334. Bağçivan G (2018) The Study of Turkish Reliability and Validity of Functional Assessment of Chronic Illness Therapy-Palliative Care (facit-pal) Scale [Dissertation] (Ankara: Hacettepe University)

335. IIlhan H (2018) Effects on the Social Life of Balanced Levels in Care of Palliative Care Patients [Dissertation] (Tokat: Tokat Gaziosmanpaşa University)

336. Öksüzoğlu S (2018) The Relationship Between the Depression and Burnout in Maintenance of Palliative Care Diseases [Dissertation] (Izmir: İzmir Bozyaka Training and Research Hospital)

337. Karadeniz N (2018) Evaluation of Symptom Control in Patients Monitored in the Palliative Care Unit [Dissertation] (Izmir: Izmir Tepecik Training and Research Hospital)

338. Kahraman Ö (2017) Perception of Social Support in Palliative Care: the Case of Ankara [Dissertation] (Konya: Selçuk University)

339. Kado A (2017) Palliative Care Needs Cancer Patients and their Proximity Questions and Solution Suggestions [Dissertation] (Istanbul: Yeni Yüzyıl University)

340. Güney H (2017) Determination of Patients with Applied Emergency Service and Palliative Care with a New Screening Method, Investigation of Needs and Symptoms by Speed, Edmonton and Karnofsky Scales [Dissertation] (Tokat: Tokat Gaziosmanpaşa University)

341. Filiz S (2017) Determination of Nursing Care Satisfaction Levels and Effective Factors in Patients with Patient Care [Dissertation] (Istanbul: Üsküdar University)

342. Sayglı M (2016) An Evaluation of Three Different Palliative Care Service Models in Terms of Patients with Cancer Diagnosis-their Family Caregivers and Cost-Effectiveness Analysis [Dissertation] (Ankara: Hacettepe University)

343. Gürakan G (2016) Effect of Aromatherapy Massage on Pain and Plasma Beta-Endorphine Levels in Palliative Cancer Patients [Dissertation] (izmir: Ege University)

344. Akyüz S (2014) Examination of Palliative Care Offered to Cancer Patients [Dissertation] (Ankara: Gazi University)

345. Uslu F (2013) Determination of the Palliative Care Practices of the Midwives and Nurses in the Gynecological Oncology Units in the Centrum of Ankara [Dissertation] (Ankara: Hacettepe University)

346. Özçelik H (2011) Examining the Effect of Case Management Model on Patient Results in Palliative Care of Cancer Patients [Dissertation] (İzmir: Ege University)

347. Turgay G (2010) Healthcare Professionals' Views on Palliative Care [Dissertation] (Ankara: Başkent University)

348. Ekici Kocakafa G (2019) Determination of the Caregiving Burden of Family Members Caring for the Inpatients in Palliative Care Unit [Dissertation] (Istanbul: Marmara University)

349. Karabuğa H (2009) Evaluation of Quality of Life Among Caregivers of Patients with Cancer [Dissertation] (Istanbul: Marmara University) 
350. Çalışkan T (2012) Inadequacy and Differences about the Attitudes in Pain Control of Cancer Patients: Assessment of Algology Department [Dissertation] (Ankara: Hacettepe University)

351. Elevli E (2012) Home Care Services in an Investigation that Determined You Need [Dissertation] (Istanbul: Beykent University)

352. Kılınç G (2015) Evaluation of the Prognosis of Cancer Patients Treated in Intensive Care Units [Dissertation] (Denizli: Pamukkale University)

353. Uzunkaya P (2016) Determining Attitudes of Nurses Working in Oncology Clinics Towards Care of Dying Patients and Principles about Death with Dignity and their Opinions Regarding Good Death [Dissertation] (Ankara: Hacettepe University)

354. Terzi K (2018) End of Life Care from the Perspectives of Patients with Cancer and Nurses [Dissertation] (Ankara: Hacettepe University)

355. Yalçın S (2018) Process Evaluation of End Stage Intensive Care Patients [Dissertation] (Denizli: Pamukkale University)

356. Özyalçın D (2019) Opinions of Cancer Patients, Nears and Nurses Related to Death and Good Death [Dissertation] (Ankara: Başkent University)

357. Şipal G (2019) Supportive Care Needs and the Disease Acceptance Level of Hematological Cancer Patients [Dissertation] (Konya: Selçuk University) 


\section{Supplementary appendix}

The supplementary tables are also available online at https://doi.org/10.6084/m9.figshare.17057009.v1.

Supplementary Table 1. Details of the included studies.

\begin{tabular}{|c|c|c|c|c|c|}
\hline $\begin{array}{c}\text { Author; year } \\
\text { (Ref.\#) }\end{array}$ & Language & $\begin{array}{l}\text { Journal paper/ } \\
\text { conference } \\
\text { presentation/ } \\
\text { poster }\end{array}$ & $\begin{array}{l}\text { Research } \\
\text { design }\end{array}$ & Aim/obj. of study & Key findings/observations \\
\hline $\begin{array}{l}\text { Silbermann } \\
\text { et al [22] }\end{array}$ & English & Journal paper & Review & $\begin{array}{l}\text { This article reviewed } \\
\text { palliative cancer care in } \\
\text { Middle Eastern countries. }\end{array}$ & $\begin{array}{l}\text { Before } 2010 \text {, palliative care (PC) was confined to only pain } \\
\text { clinics. Turkey was at number } 50 \text { th, for the consumption of } \\
\text { opioids as analgesics among all countries. After The Pallia- } \\
\text { Turk project, } 100,000 \text { patients have been treated during the } \\
\text { first } 8 \text { months of the year } 2011 \text { and the number of home } \\
\text { visits for PC was } 230,000 \text {. }\end{array}$ \\
\hline $\begin{array}{l}\text { Al-Shahri } \\
{[276]}\end{array}$ & English & Journal paper & Review & $\begin{array}{l}\text { This article reviews the } \\
\text { status of PC in seven } \\
\text { Islamic countries. }\end{array}$ & $\begin{array}{l}\text { Ongoing activates in Turkey for the implementation of PC } \\
\text { programmes and education. In 1993, the Turkish Society } \\
\text { of Algology became a regular chapter of the International } \\
\text { Association for the Study of Pain. }\end{array}$ \\
\hline $\begin{array}{l}\text { Bagcivan } \\
\text { et al [98] }\end{array}$ & English & Journal paper & Tool validation & $\begin{array}{l}\text { To evaluate validity and } \\
\text { reliability of the Barriers } \\
\text { Questionnaire II (BQ-II) in } \\
\text { Turkish cancer patients. }\end{array}$ & $\begin{array}{l}\text { Barriers Questionnaire II, BQ-II is a valid and reliable scale to } \\
\text { identify the patient-related barriers for cancer pain control in } \\
\text { Turkey. }\end{array}$ \\
\hline $\begin{array}{l}\text { Bingley and } \\
\text { Clark [19] }\end{array}$ & English & Journal paper & Review & $\begin{array}{l}\text { In this study PC, } \\
\text { development and services } \\
\text { were reviewed in the six } \\
\text { countries of the Middle } \\
\text { East Cancer Consortium. }\end{array}$ & $\begin{array}{l}\text { PC in Turkey was at the very early stages of 'capacity } \\
\text { building'. Specialist PC services and funding did not exist. } \\
\text { Terminally ill patients have access to symptoms management. } \\
\text { Only a few consultants in oncology or pain units were trained } \\
\text { to provide PC. Along with legislative and practical obstacles, } \\
\text { the opioid consumption was relatively low. }\end{array}$ \\
\hline $\begin{array}{l}\text { Bulbul et al } \\
\text { [202] }\end{array}$ & English & Journal paper & Cross-sectional & $\begin{array}{l}\text { To investigate the } \\
\text { symptoms among lung } \\
\text { cancer cases in Turkey and } \\
\text { approaches to alleviate } \\
\text { these symptoms. }\end{array}$ & $\begin{array}{l}\text { The common symptom among } 1,245 \text { lung cancer cases was } \\
\text { tiredness ( } 82.1 \%) \text {, followed by dyspnoea ( } 69.3 \%) \text {, loss of } \\
\text { appetite ( } 65.7 \%) \text {, pain ( } 65.4 \%) \text {, drowsiness }(60.8 \%) \text {, anxiety } \\
\text { ( } 57.7 \% \text { ) and depression ( } 51.1 \%) \text {. The symptoms were more } \\
\text { severe for stages III and IV patients. Symptom control was } \\
\text { insufficient even after treatment. The pain was controlled in } \\
\text { only } 21.7 \% \text { of cases, while dyspnoea in only } 12.4 \% \text { of cases } \\
\text { and appetite stimulant was useful in only } 18.9 \% \text { of cases. }\end{array}$ \\
\hline $\begin{array}{l}\text { Çınkır and } \\
\text { Kahraman } \\
{[190]}\end{array}$ & English & Journal paper & $\begin{array}{l}\text { Retrospective } \\
\text { cross-sectional }\end{array}$ & $\begin{array}{l}\text { To evaluate the data } \\
\text { of patients treated and } \\
\text { followed-up in PC service } \\
\text { of a training and research } \\
\text { hospital. }\end{array}$ & $\begin{array}{l}\text { Of the } 327 \text { patients, } 58.1 \% \text { were male. The median age was } \\
63 \text { years. The mean hospital stay was } 8 \text { days. About } 87.8 \% \\
\text { of the patients had cancer and cancer-related complications. } \\
\text { The most common cancer was the stomach ( } 32.7 \% \text { ) followed } \\
\text { by the oesophagus ( } 11.3 \%) \text {. The most common reason for } \\
\text { admission was oral intake disorder ( } 34.6 \%) \text {, pain ( } 24.5 \% \text { ) and } \\
\text { pneumonia ( } 15.0 \%) \text {. In a follow-up study, } 77 \text { patients ( } 23.5 \%) \\
\text { died within } 2 \text { years. }\end{array}$ \\
\hline $\begin{array}{l}\text { Cleary et al } \\
\text { [120] }\end{array}$ & English & Journal paper & Review & $\begin{array}{l}\text { This study was aimed } \\
\text { at identifying opioid } \\
\text { availability and } \\
\text { accessibility in the Middle } \\
\text { East. }\end{array}$ & $\begin{array}{l}\text { There are no restrictions on the eligibility of a patient for } \\
\text { opioid analgesics in Turkey. Physicians can prescribe opioids } \\
\text { for up to } 10 \text { days. The Statistical purposes Daily Dose for } \\
\text { per Day per million people (S-DDD) was raised from } 120 \mathrm{mg} \\
\text { during } 1997-1999 \text { to } 580 \mathrm{mg} \text { in the year 2007-09. }\end{array}$ \\
\hline
\end{tabular}


Supplementary Table 1. Details of the included studies. (Continued).

\begin{tabular}{|c|c|c|c|c|c|}
\hline $\begin{array}{l}\text { Dincer et al } \\
\text { [115] }\end{array}$ & English & Journal paper & Cross-sectional & $\begin{array}{l}\text { This study was planned to } \\
\text { determine the attitudes } \\
\text { of nurses in PC centres } \\
\text { towards the patient safety } \\
\text { culture. }\end{array}$ & $\begin{array}{l}\text { Out of } 487 \text { PC nurses, } 76.5 \% \text { admitted that they had } \\
\text { received patient safety training. Perception of the patient } \\
\text { safety culture using the Patient Safety Culture Scale was } \\
\text { found positive. } 94.2 \% \text { admitted an increased risk of errors } \\
\text { because of excessive workload. } 82.1 \% \text { thought that paucity } \\
\text { of logistical and resources affected the patient safety culture. }\end{array}$ \\
\hline Elcigil [52] & English & Journal paper & Review & $\begin{array}{l}\text { This review provides } \\
\text { an oncology nurse's } \\
\text { perspective regarding the } \\
\text { status of PC. }\end{array}$ & $\begin{array}{l}\text { A significant proportion of the Turkey population does not } \\
\text { have access to PC and most terminally ill cancer patients } \\
\text { were treated by pain specialists and medical oncologists. } \\
\text { Barriers to the development of PC nursing were; Lack of } \\
\text { certified PC education and training programmes, limited } \\
\text { research, lack of public awareness, shortage of nursing staff } \\
\text { and limited knowledge about opioid analgesics use. }\end{array}$ \\
\hline $\begin{array}{l}\text { Emuk and } \\
\text { Naz [58] }\end{array}$ & English & Journal paper & Review & $\begin{array}{l}\text { This article briefly } \\
\text { described the Pallia-Turk } \\
\text { project and highlighted } \\
\text { the situation of PC in } \\
\text { Turkey. }\end{array}$ & $\begin{array}{l}\text { The aim of the Pallia-Turk project was 1) to increase } \\
\text { morphine availability, 2) legislations for morphine } \\
\text { prescription, 3) training of medical staff and 4) } \\
\text { implementation of a community-based PC programme. The } \\
\text { project consists of primary, secondary and tertiary level PC } \\
\text { centres. PC was the weakest part of the National Cancer } \\
\text { Control Programme. The project needs to clarify education, } \\
\text { training medical ethics and standardise tools to evaluate } \\
\text { psychosocial needs. }\end{array}$ \\
\hline $\begin{array}{l}\text { Ertaş et al } \\
{[277]}\end{array}$ & English & Journal paper & Clinical trial & $\begin{array}{l}\text { To evaluate the } \\
\text { effectiveness of } \\
\text { subcutaneously } \\
\text { implanted epidural ports } \\
\text { in the management } \\
\text { of advanced-stage } \\
\text { gynaecologic cancer pain. }\end{array}$ & $\begin{array}{l}\text { Morphine administration via subcutaneously implanted } \\
\text { epidural ports provides excellent pain relief in gynaecologic } \\
\text { cancer without side effects and increased patient quality of } \\
\text { life. }\end{array}$ \\
\hline Eyigor [73] & English & Journal paper & Cross-sectional & $\begin{array}{l}\text { To evaluate the } \\
\text { knowledge of medical } \\
\text { students on PC and their } \\
\text { views on PC in clinical } \\
\text { practice. }\end{array}$ & $\begin{array}{l}\text { Among } 175 \text { fifth-year, medical students most gave correct } \\
\text { answers about PC philosophy. Concerning symptom control, } \\
\text { the answers were mostly incorrect. } 64.6 \% \text { stated that the } \\
\text { education on PC was insufficient and } 90.3 \% \text { did not receive } \\
\text { training on end-of-life communication skills. }\end{array}$ \\
\hline $\begin{array}{l}\text { Goksu et al } \\
\text { [196] }\end{array}$ & English & Journal paper & $\begin{array}{l}\text { Retrospective/ } \\
\text { cross-sectional }\end{array}$ & $\begin{array}{l}\text { To evaluate the aggressive } \\
\text { use of chemotherapy } \\
\text { among cancer patients } \\
\text { in Turkey near the end } \\
\text { of life. }\end{array}$ & $\begin{array}{l}\text { A total of } 373 \text { stage IV solid tumours patients died } \\
\text { between years } 2010 \text { and } 2011 \text {. Of these, } 23.9 \% \text { underwent } \\
\text { chemotherapy a month before their death. The likelihood of } \\
\text { chemotherapy was influenced by patients' age, more recent } \\
\text { diagnosis and performance status. No association was found } \\
\text { between gender and tumour type with chemotherapy. }\end{array}$ \\
\hline $\begin{array}{l}\text { Hacikamiloglu } \\
\text { et al [43] }\end{array}$ & English & Journal paper & Review & $\begin{array}{l}\text { This review article } \\
\text { described the Community } \\
\text { Palliative Care programme } \\
\text { in Turkey. }\end{array}$ & $\begin{array}{l}\text { PC training programmes were organised in collaboration with } \\
\text { the Turkish MoH and the Middle East Cancer Consortium } \\
\text { (MECC) between } 2004 \text { and } 2014 \text { and a total of } 434 \text { people } \\
\text { participated. Among the participants, } 27.1 \% \text { were nurses and } \\
26.9 \% \text { oncologists. The MoH launched a national home- } \\
\text { based PC programme with } 407 \text { home care teams in } 2010 \text {. By } \\
\text { the year } 2014 \text {, there were } 834 \text { home care teams providing } \\
\text { services to } 416,175 \text { patients. In addition to that, there were } \\
18 \text { PC centres in the country. }\end{array}$ \\
\hline
\end{tabular}


Supplementary Table 1. Details of the included studies. (Continued).

\begin{tabular}{|c|c|c|c|c|c|}
\hline $\begin{array}{l}\text { Hajjar et al } \\
\text { [18] }\end{array}$ & English & Journal paper & Review & $\begin{array}{l}\text { This review article focuses } \\
\text { on the prevalence of the } \\
\text { ageing population in the } \\
\text { Middle East including } \\
\text { Turkey and its implications } \\
\text { on cancer incidence and } \\
\text { care. }\end{array}$ & $\begin{array}{l}\text { In the year } 2000 \text {, about } 13.1 \% \text { of all deaths in Turkey were } \\
\text { due to cancer and it is projected to rise } 16.2 \% \text { in } 2030 \text {. In } \\
2006 \text {, direct cost for cancer treatment constituted } 11 \% \text { of } \\
\text { overall healthcare expenditure. Regarding terminal stage } \\
\text { cancer patients 'home care' is generally provided by relatives } \\
\text { in Turkish society. }\end{array}$ \\
\hline Isıkhan [47] & English & Journal paper & Review & $\begin{array}{l}\text { This review article } \\
\text { highlights the current } \\
\text { level and future status of } \\
\text { social work in PC services } \\
\text { in Turkey. }\end{array}$ & $\begin{array}{l}\text { The effort for PC for cancer patients was started with the } \\
\text { initiative of TMoH Fight Against Cancer in the year } 2003 \text {. } \\
\text { The psychosocial subcommittee was formulated and a } \\
\text { training programme for social support was discussed. By } \\
\text { the year } 2015 \text {, there were } 31 \text { certified PC centres with } 389 \\
\text { beds and } 50 \text { social workers providing support in oncology } \\
\text { units of hospitals. Difficulties experienced by National } \\
\text { Cancer Advisory Board were; excess workload, difficulty in } \\
\text { identifying PC needs, reluctance to discuss death, ineffective } \\
\text { communication skills and lack of training of health personnel. }\end{array}$ \\
\hline $\begin{array}{l}\text { lyigun et al } \\
\text { [110] }\end{array}$ & English & Journal paper & Tool validation & $\begin{array}{l}\text { To examine the } \\
\text { psychometric properties } \\
\text { of the Turkish version } \\
\text { of the Cancer Behavior } \\
\text { Inventory-Brief Version } \\
\text { (CBI-B). }\end{array}$ & $\begin{array}{l}\text { The Turkish version of the Cancer Behavior Inventory- } \\
\text { Brief Version was a valid and reliable inventory for the } \\
\text { psychometric evaluation of Turkish cancer patients coping } \\
\text { with cancer. }\end{array}$ \\
\hline $\begin{array}{l}\text { Kahveci and } \\
\text { Gokcinar } \\
\text { [213] }\end{array}$ & English & Journal paper & Cross-sectional & $\begin{array}{l}\text { To determine the level of } \\
\text { knowledge of PC among } \\
\text { the family members of } \\
\text { patients requiring PC. }\end{array}$ & $\begin{array}{l}\text { Among } 150 \text { family members of patients receiving PC, } \\
68.0 \% \text { had no prior knowledge of PC. In all, } 50.7 \% \text { of the } \\
\text { participants thought that PC could prolong life, and } 32.7 \% \\
\text { thought that PC was designed to be curative. }\end{array}$ \\
\hline $\begin{array}{l}\text { Karaoren et al } \\
\text { [193] }\end{array}$ & English & Journal paper & $\begin{array}{l}\text { Retrospective/ } \\
\text { cross-sectional }\end{array}$ & $\begin{array}{l}\text { To determine the need for } \\
\text { a 'hospice unit' in Turkey. }\end{array}$ & $\begin{array}{l}\text { One year (2010-2011) record of } 287 \text { patients from the } \\
\text { emergency department of a university hospital found that } \\
\text { approximately half of all patients had a diagnosis of cancer, } \\
\text { and } 47 \% \text { of those had grade IV disease. } 63.8 \% \text { of patients } \\
\text { for whom intensive care monitoring was recommended were } \\
\text { over the age of } 60 \text { years, } 20 \% \text { had advanced-stage cancer } \\
\text { and the predicted mortality rate was nearly } 60 \% \text {. }\end{array}$ \\
\hline Kinay [46] & English & Journal paper & Review & $\begin{array}{l}\text { This article describes the } \\
\text { establishment of a PC unit } \\
\text { in a university hospital. }\end{array}$ & $\begin{array}{l}\text { Describes the efforts for establishment of a multidisciplinary } \\
\text { PC unit in the oncology department of a university hospital } \\
\text { and activities for the initiation of MS and Ph.D. programmes } \\
\text { in Palliative and Supportive at the university. }\end{array}$ \\
\hline Komurcu [16] & English & Journal paper & Review & $\begin{array}{l}\text { This review outlines } \\
\text { the history of PC } \\
\text { development in Turkey. }\end{array}$ & $\begin{array}{l}\text { The concept of PC in Turkey was started after the } \\
\text { establishment of the Association of Pain management } \\
\text { in 1998. Subgroup for Supportive Care in Cancer was } \\
\text { formulated within the Turkish Oncology Group and efforts for } \\
\text { the development of PC programme in turkey were initiated } \\
\text { after } 2000 \text {. }\end{array}$ \\
\hline
\end{tabular}


Supplementary Table 1. Details of the included studies. (Continued).

\begin{tabular}{|c|c|c|c|c|c|}
\hline $\begin{array}{l}\text { Lynch et al } \\
\text { [33] }\end{array}$ & English & Journal paper & Review & $\begin{array}{l}\text { This descriptive study } \\
\text { aimed to categorise the } \\
\text { countries according to } \\
\text { PC development and to } \\
\text { present changes in PC } \\
\text { over time. }\end{array}$ & $\begin{array}{l}\text { All countries around the globe were classified into six groups } \\
\text { based on PC service provision. Turkey was placed in Group } \\
\text { 3b (generalised PC provision) along with Albania, Argentina, } \\
\text { Belarus, Bosnia and Herzegovina, Cote D'ivoire, Croatia, } \\
\text { Cyprus, Czech Republic, Georgia, India, Jordan, Lithuania, } \\
\text { Malta, Nepal, Portugal and Swaziland. It was cited that there } \\
\text { were } 14 \text { PC services available in the country and the Ratio of } \\
\text { Palliative Care Services to Population was 1: } 5344000 \text {. }\end{array}$ \\
\hline $\begin{array}{l}\text { Mojen et al } \\
\text { [135] }\end{array}$ & English & Journal paper & Review & $\begin{array}{l}\text { In this study paediatric PC } \\
\text { system in Egypt, Lebanon, } \\
\text { Jordan, Turkey and Iran } \\
\text { has been summarised. }\end{array}$ & $\begin{array}{l}\text { The first PC unit for children established in 2011, at Dokuz } \\
\text { Eylül hospital in Izmir. In- and out-patients services were } \\
\text { provided by the multidisciplinary team of doctors, nurses, } \\
\text { psychologists and social workers. } \\
\text { Training workshops, to create a model of PC, were held and a } \\
\text { total of } 434 \text { people in Turkey had been trained in PC by } 2014 \text {. }\end{array}$ \\
\hline $\begin{array}{l}\text { Mutafoglu } \\
\text { and Group } \\
\text { DEUPCS } \\
{[134]}\end{array}$ & English & Journal paper & Review & $\begin{array}{l}\text { This article describes } \\
\text { establishment of PC unit } \\
\text { in a university Hospital. }\end{array}$ & $\begin{array}{l}\text { Institutional efforts for establishment of PC unit in a } \\
\text { university hospital in Turkey. It also describes how a } \\
\text { multidisciplinary PC team provides in and outpatient services. }\end{array}$ \\
\hline $\begin{array}{l}\text { Özmen et al } \\
\text { [260] }\end{array}$ & English & Journal paper & Review & $\begin{array}{l}\text { This article presents } \\
\text { the summary of The } \\
\text { 2nd Turkish General } \\
\text { Medical Assembly Clinical } \\
\text { Oncology Study Group } \\
\text { meeting held in Istanbul } \\
\text { in October } 2015 \text {. }\end{array}$ & $\begin{array}{l}\text { It was emphasised that PC should be integrated as a } \\
\text { component of cancer treatment, through a multidisciplinary } \\
\text { approach, PC training should include physicians, nurses and } \\
\text { healthcare staff, the care should be based on a patient's need } \\
\text { and wishes and the concepts of national PC should be made } \\
\text { in line with the World Health Organization criteria; moreover, } \\
\text { necessary legal arrangements should be provided for the } \\
\text { right for DNR and regulations on terminal sedation decisions. }\end{array}$ \\
\hline $\begin{array}{l}\text { Ozgul et al } \\
\text { [12] }\end{array}$ & English & Journal paper & Review & $\begin{array}{l}\text { This article reviews opioid } \\
\text { availability, accessibility } \\
\text { and regulatory barriers for } \\
\text { cancer patients in Turkey. }\end{array}$ & $\begin{array}{l}\text { There were } 72 \text { pain control units and only } 10 \text { PC centres } \\
\text { across the whole country. The morphine consumption rate } \\
\text { per capita was low, and the accessibility, as well as the } \\
\text { availability of morphine products, is limited in the country. } \\
\text { Family physicians will have the right to prescribe opioids. }\end{array}$ \\
\hline $\begin{array}{l}\text { Ozgul et al } \\
{[28]}\end{array}$ & English & Journal paper & Review & $\begin{array}{l}\text { This manuscript } \\
\text { summarises the situation } \\
\text { before the Pallia-Turk } \\
\text { Project and updates of } 2 \\
\text { years period after of that. }\end{array}$ & $\begin{array}{l}\text { The two main objectives of the Pallia-Turk Project were } \\
\text { the availability of opioids and the implementation of a } \\
\text { community-based PC model. The availability of different } \\
\text { types of morphine in the markets has been increasing } \\
\text { through new legislation. The medical staff will be trained } \\
\text { against opiophobia. A telephone number had been } \\
\text { established for patients in need of home care. Out of } 190 \\
\text { home visits, most had neurological diseases and only } 4 \% \text { had } \\
\text { cancer. }\end{array}$ \\
\hline $\begin{array}{l}\text { Ozcelik et al } \\
\text { [107] }\end{array}$ & English & Journal paper & Tool validation & $\begin{array}{l}\text { This study aimed to } \\
\text { perform a psychometric } \\
\text { evaluation of the (EORTC } \\
\text { QLQ-C15-PAL). }\end{array}$ & $\begin{array}{l}\text { The Turkish version of the European Organization } \\
\text { for Research and Treatment of Cancer Quality of Life } \\
\text { Questionnaire-Core 15-PAL is a valid and reliable tool to } \\
\text { determine the quality of life of advanced cancer patients who } \\
\text { are undergoing palliative treatment in Turkey. }\end{array}$ \\
\hline
\end{tabular}


Supplementary Table 1. Details of the included studies. (Continued).

\begin{tabular}{|c|c|c|c|c|c|}
\hline $\begin{array}{l}\text { Ozcelik et al } \\
\text { [106] }\end{array}$ & English & Journal paper & Review & $\begin{array}{l}\text { To determine the level of } \\
\text { satisfaction of } 145 \text { family } \\
\text { members of patients with } \\
\text { advanced-stage cancer } \\
\text { receiving PC. }\end{array}$ & $\begin{array}{l}\text { The average total family satisfaction score was } 76.87 \pm 1.14 \text {. } \\
\text { A significant relationship was found between the family } \\
\text { member's level of satisfaction and possession of sufficient } \\
\text { information about the patient. }\end{array}$ \\
\hline $\begin{array}{l}\text { Polat and } \\
\text { Karatas [80] }\end{array}$ & English & Journal paper & Cross-sectional & $\begin{array}{l}\text { This study was aimed } \\
\text { to determine nursing } \\
\text { students' knowledge } \\
\text { about PC. }\end{array}$ & $\begin{array}{l}\text { Out of } 658 \text { nursing students, only } 5.3 \% \text { correctly answered } \\
\text { all items about PC, while } 26.3 \% \text { gave correct answers in line } \\
\text { with the PC theoretical framework and } 5.3 \% \text { gave correct } \\
\text { responses for symptom management. }\end{array}$ \\
\hline $\begin{array}{l}\text { Sahin et al } \\
{[101]}\end{array}$ & English & Journal paper & Cross-sectional & $\begin{array}{l}\text { Relationships between } \\
\text { demographic variables } \\
\text { and hopelessness and } \\
\text { depression among } \\
\text { terminally ill cancer } \\
\text { patients. }\end{array}$ & $\begin{array}{l}\text { The hopelessness score of } 216 \text { terminally ill cancer patients } \\
\text { was significantly higher for cancer patients who were; female, } \\
\text { illiterate, married and living in rural areas. Hopelessness and } \\
\text { depression were significantly higher for those having; longer } \\
\text { duration of disease, receiving radiotherapy and advanced } \\
\text { metastatic disease. The significantly negative association } \\
\text { between hopelessness, depression and perceived social } \\
\text { support from family was evident. }\end{array}$ \\
\hline $\begin{array}{l}\text { Seven et al } \\
{[108]}\end{array}$ & English & Journal paper & Cross-sectional & $\begin{array}{l}\text { To identify gynaecologic } \\
\text { cancer patients' PC needs. }\end{array}$ & $\begin{array}{l}\text { Out of } 134 \text { gynaecologic cancer patients with PC needs, } \\
69.4 \% \text { had ovarian cancer and of all } 52.2 \% \text { had stage- } 3-4 \\
\text { cancer. } 33.5 \% \text { expressed as they were a burden for their } \\
\text { families and about } 28.4 \% \text { feel lonely at some level. The } \\
\text { most prevalent unmet needs were tiredness }(60.5 \%) \text {, feel } \\
\text { depression ( } 47.4 \% \text { ) and lack of appetite }(38.5 \%) \text {, pain (38.1\%) } \\
\text { and nausea ( } 26.3 \%) \text {. }\end{array}$ \\
\hline $\begin{array}{l}\text { Silbermann } \\
{[121]}\end{array}$ & English & Journal paper & Review & $\begin{array}{l}\text { This review article } \\
\text { determines and compares } \\
\text { the medical use of opioids } \\
\text { consumption in Middle } \\
\text { Eastern Populations. }\end{array}$ & $\begin{array}{l}\text { Between } 2004 \text { and 2007, the consumption of morphine has } \\
\text { been fluctuating at doses of about } 0.1 \mathrm{mg} / \text { capita in Turkey. }\end{array}$ \\
\hline $\begin{array}{l}\text { Silbermann } \\
\text { et al [34] }\end{array}$ & English & Journal paper & Survey & $\begin{array}{l}\text { To determine knowledge, } \\
\text { beliefs, barriers and } \\
\text { resources regarding PC } \\
\text { services in Middle Eastern } \\
\text { countries. }\end{array}$ & $\begin{array}{l}\text { Cancer patients were informed by treating physicians about } \\
\text { different care options including PC. The opioid consumption } \\
\text { in Turkey during } 2011 \text { was } 12.220 \text { milligrams per capita and it } \\
\text { was five times lesser than the global mean value. }\end{array}$ \\
\hline $\begin{array}{l}\text { Süren et al } \\
\text { [95] }\end{array}$ & English & Journal paper & Cross-sectional & $\begin{array}{l}\text { This descriptive study was } \\
\text { aimed to investigate the } \\
\text { symptoms and needs of } \\
\text { terminal cancer patients. }\end{array}$ & $\begin{array}{l}\text { Of } 107 \text { patients, } 43 \% \text { had gastrointestinal and } 25.3 \% \text { had } \\
\text { genitourinary cancer. The common symptoms were fatigue } \\
\text { ( } 98.1 \%) \text {, pain }(92.5 \%) \text {, insomnia }(92.5 \%) \text {, loss of appetite } \\
(76.6 \%) \text {, constipation }(71 \%) \text {, dyspnoea ( } 63.6 \%) \text {, nausea } \\
(60.7 \%) \text {, cough ( } 57.9 \%) \text { and vomiting }(48.6 \%) \text {. Formal PC is } \\
\text { limited in northern Turkey and most patients were referred } \\
\text { at the late stages of the disease and with the severity of the } \\
\text { symptom. }\end{array}$ \\
\hline $\begin{array}{l}\text { Turgay and } \\
\text { Kav [76] }\end{array}$ & English & Journal paper & Cross-sectional & $\begin{array}{l}\text { To explore health } \\
\text { professional's view of PC. }\end{array}$ & $\begin{array}{l}\text { Among } 369 \text { healthcare professionals, most of the } \\
\text { respondents admitted lack of continuing PC education } \\
\text { programme and more than half affirmed that they had never } \\
\text { received education in palliative care. However, the majority } \\
\text { of the respondent had a clear meaning of PC and make the } \\
\text { correct option. }\end{array}$ \\
\hline
\end{tabular}


Supplementary Table 1. Details of the included studies. (Continued).

\begin{tabular}{|c|c|c|c|c|c|}
\hline $\begin{array}{l}\text { Oğuz et al } \\
\text { [217] }\end{array}$ & English & Journal paper & Review & $\begin{array}{l}\text { This article review end-of- } \\
\text { life care in Turkey. }\end{array}$ & $\begin{array}{l}\text { With the population ageing, the inadequacy of end-of- } \\
\text { life healthcare is a critical issue for Turkey. The healthcare } \\
\text { provider must learn to communicate the risks and benefits } \\
\text { of medical procedures and alternatives treatment with } \\
\text { terminally ill patients as well as their relatives. Legislative } \\
\text { procedure for DNR and public discussion about end-of-life } \\
\text { care are needed. }\end{array}$ \\
\hline $\begin{array}{l}\text { Yildirim and } \\
\text { Tanriverdi } \\
\text { [195] }\end{array}$ & English & Journal paper & $\begin{array}{l}\text { Retrospective/ } \\
\text { cross-sectional }\end{array}$ & $\begin{array}{l}\text { This retrospective study } \\
\text { focused on how often and } \\
\text { why patients with cancer } \\
\text { visited the emergency } \\
\text { department (ED) of a } \\
\text { university hospital before } \\
\text { death. }\end{array}$ & $\begin{array}{l}\text { The medical record of } 107 \text { deceased cancer cases showed } \\
60 \% \text { of cases had at least one visit to ED within } 1 \text { month } \\
\text { before death. Of these, } 38 \% \text { were discharged, } 9 \% \text { died in } \\
\text { the ED while } 53 \% \text { were hospitalised. The most common site } \\
\text { of the primary tumour was the lung (38\%), the three most } \\
\text { common presenting symptoms were dyspnoea/shortness of } \\
\text { breath, pain and deterioration in general health status. The } \\
\text { most common reason for hospitalisation was 'social support'. }\end{array}$ \\
\hline $\begin{array}{l}\text { Zeybek Unsal } \\
\text { and Büken } \\
{[218]}\end{array}$ & English & Journal paper & Review & $\begin{array}{l}\text { To examine existing } \\
\text { legislative regulations on } \\
\text { PC in Turkey and compare } \\
\text { with Europe. }\end{array}$ & $\begin{array}{l}\text { Patients' Rights Implementation Directive has provisions } \\
\text { for patients to refuse treatment or withdrawing treatment. } \\
\text { Article } 13 \text { of the Regulation forbids euthanasia. The law } \\
\text { distinguishes between assisted suicide and withholding or } \\
\text { withdrawing life continuing treatments. The 'Directive on } \\
\text { Implementation Fundamentals and Procedures of Palliative } \\
\text { Care Services' was a force through } 07 / 07 / 2015 \text { and states } \\
\text { that in PC, patients will be informed about patient rights, } \\
\text { obligations and details of care service. The patient also has } \\
\text { the right to refuse to have PC. }\end{array}$ \\
\hline $\begin{array}{l}\text { Ozcelik et al } \\
\text { [21] }\end{array}$ & English & Journal paper & Review & $\begin{array}{l}\text { To describe PC activities } \\
\text { in the field of oncology in } \\
\text { Turkey. }\end{array}$ & $\begin{array}{l}\text { PC services were not provided at the specialist level in } \\
\text { Turkey. Barriers to the provision of PC were; lack of trained } \\
\text { personnel, social security coverage for home-based PC cost, } \\
\text { legal issues and opioid phobia. Turkey ranks 44th among } 51 \\
\text { countries of the WHO European region for per-capita opioid } \\
\text { consumption. The right of dying patients to issue advanced } \\
\text { directives has not been established by law in turkey and the } \\
\text { DNR order is not legal. }\end{array}$ \\
\hline $\begin{array}{l}\text { Ben-Arye et al } \\
\text { [88] }\end{array}$ & English & Journal Paper & Cross-Sectional & $\begin{array}{l}\text { Integration of } \\
\text { complementary medicine } \\
\text { in supportive cancer care } \\
\text { in the Middle East. }\end{array}$ & $\begin{array}{l}\text { The use of complementary and traditional medicine (CTM) } \\
\text { among patients with cancer in the Middle East ranges from } \\
35 \% \text { in Iran to nearly } 100 \% \text { in Jordan. Use of CTM is } 57 \% \\
\text { in Turkey. Only limited research has been published on the } \\
\text { integration of CTM in cancer care across the Middle East. }\end{array}$ \\
\hline $\begin{array}{l}\text { Uslu-Sahan } \\
\text { et al [79] }\end{array}$ & English & Journal paper & Cross-sectional & $\begin{array}{l}\text { To assess knowledge, } \\
\text { practice and opinions } \\
\text { about barriers toward PC } \\
\text { among nurses working in } \\
\text { gynaecologic oncology } \\
\text { units. }\end{array}$ & $\begin{array}{l}\text { Among } 65 \text { nurses working in gynaecologic oncology units, } \\
52.3 \% \text { did not receive any knowledge regarding PC. The } \\
\text { training received was communication skills }(96.8 \%) \text {, pain } \\
\text { management ( } 96.8 \%) \text { and symptom control }(96.8 \%) \text {. About } \\
73.8 \% \text { did not talk about death with patients and their } \\
\text { families. One of the most common barriers faced by nurses } \\
\text { was opioid phobia experienced by patients }(66.2 \%) \text { and } \\
\text { healthcare professionals ( } 41.5 \%) \text {. }\end{array}$ \\
\hline
\end{tabular}


Supplementary Table 1. Details of the included studies. (Continued).

\begin{tabular}{|c|c|c|c|c|c|}
\hline $\begin{array}{l}\text { Erdine et al } \\
{[15]}\end{array}$ & English & Journal paper & Review & $\begin{array}{l}\text { A concise overview of } \\
\text { early days of PC in Turkey. }\end{array}$ & $\begin{array}{l}\text { Pain \& PC have been the important target of the Turkish } \\
\text { Society of Algology. Palliative care Campaigns of the WHO } \\
\text { were organised by the Turkish Society of Algology. WHO } \\
\text { Cancer Pain management booklets were translated into the } \\
\text { Turkish language. }\end{array}$ \\
\hline $\begin{array}{l}\text { Alkan et al } \\
\text { [109] }\end{array}$ & English & Journal paper & Cross-sectional & $\begin{array}{l}\text { To evaluate the } \\
\text { predictors of Persistent } \\
\text { postmastectomy pain } \\
\text { syndrome (PMPS) and } \\
\text { posttraumatic stress } \\
\text { disorder (PTSD) in breast } \\
\text { cancer survivors. }\end{array}$ & $\begin{array}{l}\text { Among } 614 \text { breast cancer survivors, the incidence of PMPS } \\
\text { was } 45.1 \% \text {. PTSD was documented in } 75 \% \text { of cases. Low } \\
\text { income, presence of PTSD and }<46 \text { months after surgery } \\
\text { were associated with increased risk of PMPS. }\end{array}$ \\
\hline Büken [278] & English & Journal paper & Review & $\begin{array}{l}\text { In this paper, the concepts } \\
\text { and application of medical } \\
\text { ethics specific to end-of- } \\
\text { life PC were discussed. }\end{array}$ & $\begin{array}{l}\text { The physicians encounter many ethical dilemmas coming } \\
\text { at the end-of-life stage of patients with cancer. Dealing } \\
\text { with these dilemmas, the decisions of the interested parties } \\
\text { (physician, medical personnel, patient, patient's family, health } \\
\text { institution) about the actuation of the clinical and ethical } \\
\text { decision-making processes are affected by the society's } \\
\text { moral, social, cultural and legal structure as well as the health } \\
\text { policy and health economies of the state. }\end{array}$ \\
\hline $\begin{array}{l}\text { Sert and } \\
\text { Guven et al } \\
{[219]}\end{array}$ & English & Journal paper & Review & $\begin{array}{l}\text { This paper examines the } \\
\text { ethico-legal problems } \\
\text { regarding the right to } \\
\text { refuse treatment in } \\
\text { Turkey's. }\end{array}$ & $\begin{array}{l}\text { Article 17, paragraph } 2 \text { of the } 1982 \text { Constitution of the } \\
\text { Republic of Turkey provides a legal framework governing the } \\
\text { limits of the right to refuse treatment in Turkey. However, } \\
\text { interpretation of the scope of this framework is complex and } \\
\text { it is needed to be clarified and amended under international } \\
\text { conventions and fundamental human rights. }\end{array}$ \\
\hline $\begin{array}{l}\text { Tanrıverdi } \\
\text { et al [102] }\end{array}$ & English & Journal paper & Cross-sectional & $\begin{array}{l}\text { To evaluate the } \\
\text { caregiver's burden and } \\
\text { prevalence of depression } \\
\text { among caregivers of } \\
\text { cancer patients receiving } \\
\text { chemotherapy. }\end{array}$ & $\begin{array}{l}\text { Depression was found among } 64 \% \text { of the caregivers. The } \\
\text { presence of depression was associated with young age, being } \\
\text { female, high education, low economic status, financial loss } \\
\text { during treatment, patient's lack of knowledge about his/ } \\
\text { her diagnosis, metastatic disease and short survival time. It } \\
\text { was found that among } 968 \text { participants } 36 \% \text { had suffered } \\
\text { financial loss, } 56 \% \text { had incurred diminished social activities, } \\
42 \% \text { confirmed a lack of self-care and } 18 \% \text { had lost their } \\
\text { jobs. The patient's lack of knowledge of the diagnosis was the } \\
\text { independent risk factor caregivers burden. }\end{array}$ \\
\hline $\begin{array}{l}\text { Tanrıverdi } \\
\text { et al [194] }\end{array}$ & English & Journal paper & $\begin{array}{l}\text { Retrospective/ } \\
\text { cross-sectional }\end{array}$ & $\begin{array}{l}\text { Identify the } \\
\text { characteristics of cancer } \\
\text { patients admitted to the } \\
\text { emergency department in } \\
\text { Southwest Turkey. }\end{array}$ & $\begin{array}{l}\text { A total of } 304 \text { emergency department visits by } 102 \text { cancer } \\
\text { patients between August } 2011 \text { and September } 2013 \text {. The } \\
\text { majority of patients were male (65\%) and over } 65 \text { years } \\
\text { of age ( } 52 \%) \text {. About } 30 \% \text { had lung cancer, among all } 32 \% \\
\text { presented with dyspnoea, } 53 \text { had metastasis. The Eastern } \\
\text { Cooperative Oncology Group-ECOG performance status was } \\
\text { poor (score } 3 \text { to } 4 \text { ) among } 68 \% \text { of patients. }\end{array}$ \\
\hline
\end{tabular}


Supplementary Table 1. Details of the included studies. (Continued).

\begin{tabular}{|c|c|c|c|c|c|}
\hline $\begin{array}{l}\text { Walker et al } \\
\text { [279] }\end{array}$ & English & Journal paper & Review & $\begin{array}{l}\text { This paper summarises } \\
\text { the status of PC in the } \\
\text { United States, Turkey, and } \\
\text { Malawi. It also describes } \\
\text { collaborative projects in } \\
\text { cancer and PC in these } \\
\text { countries. }\end{array}$ & $\begin{array}{l}\text { The University of Alabama at Birmingham School of Nursing } \\
\text { (UABSON), through a Pan American Health Organization/ } \\
\text { World Health Organization Nursing Collaborating Center, } \\
\text { has initiated collaborative projects in cancer and PC between } \\
\text { the USA, Turkey and Malawi, to strengthen initiatives that } \\
\text { can ultimately transform the practice. The UABSON has } \\
\text { collaborated with Turkish nurses and researchers to develop } \\
\text { a PC network and research. }\end{array}$ \\
\hline $\begin{array}{l}\text { Yüceege et al } \\
\text { [105] }\end{array}$ & English & Journal paper & Tool validation & $\begin{array}{l}\text { To identify the clinical } \\
\text { utility of Memorial } \\
\text { Symptom Assessment- } \\
\text { Short Form and } \\
\text { Condensed Memorial } \\
\text { Symptom Assessment } \\
\text { Scale in Turkish lung } \\
\text { cancer patients. }\end{array}$ & $\begin{array}{l}\text { Memorial Symptom Assessment-Short Form and Condensed } \\
\text { Memorial Symptom Assessment Scale can be used in lung } \\
\text { cancer patients The Cronbach's alpha coefficients were } \\
0.861 \text { ( } 1.785-0.915) \text { for MSAS-SF and } 0.728(0.566-0.835) \\
\text { for CMSAS. Scores from both assessments are significantly } \\
\text { higher in patients with metastatic disease, and additionally, } \\
\text { all of the MSAS-SF subscales were significantly higher in } \\
\text { metastatic patients. }\end{array}$ \\
\hline $\begin{array}{l}\text { Kucukoner } \\
\text { et al [89] }\end{array}$ & English & Journal paper & Cross-sectional & $\begin{array}{l}\text { To determine the } \\
\text { frequency, type and } \\
\text { associated factors of } \\
\text { complementary and } \\
\text { alternative medicine } \\
\text { (CAM) by cancer patients. }\end{array}$ & $\begin{array}{l}\text { It was found that at least one CAM method was used by } 62 \% \\
\text { ( } n=201 \text { ) of the patients. } 82.5 \% \text { of patients treated with CAM } \\
\text { were using at least one herbal species. Among CAM users, } \\
40.9 \% \text { were using herbal mixtures and } 39.8 \% \text { were using } \\
\text { Urtica dioica. CAM was preferred more frequently by the } \\
\text { patients, age } 40-60 \text { with metastatic stage, receiving palliative } \\
\text { treatment, chemotherapy. }\end{array}$ \\
\hline $\begin{array}{l}\text { Soylu et al } \\
\text { [93] }\end{array}$ & English & Journal paper & Cross-sectional & $\begin{array}{l}\text { To explore advanced } \\
\text { breast cancer patients' } \\
\text { knowledge of treatment } \\
\text { intent and expectation } \\
\text { of illness course and to } \\
\text { evaluate their relationship } \\
\text { with optimism, hope and } \\
\text { quality of life (QoL). }\end{array}$ & $\begin{array}{l}\text { Out of } 55 \text { advanced breast cancer patients, treated in the } \\
\text { ambulatory clinic of the University Hospital, } 32 \text { ( } 58.2 \%) \\
\text { patients had an inaccurate perception of treatment intent, } \\
\text { believing the aim of treatment was the cure. Regarding } \\
\text { the expectation of disease course, only } 21 \text { ( } 38.2 \%) \text { had a } \\
\text { realistic expectation that their disease may remain stable } \\
\text { or may progress over a year. Also, the awareness of disease } \\
\text { progression and perception of goals of treatment was } \\
\text { significantly related to hope and optimism scores but not } \\
\text { with QoL. }\end{array}$ \\
\hline $\begin{array}{l}\text { Kafadar et al } \\
{[64]}\end{array}$ & English & Journal paper & Cross-sectional & $\begin{array}{l}\text { To evaluate the } \\
\text { managerial perspectives } \\
\text { and opinions of the } \\
\text { hospital managers and } \\
\text { clinical directors about } \\
\text { specialised PC centres. }\end{array}$ & $\begin{array}{l}\text { Interviews were carried out with } 70 \text { hospital managers } \\
\text { and clinical directors in two oncology hospitals in Istanbul. } \\
\text { The need for establishment of PC unit in the hospital was } \\
\text { suggested by most ( } 87 \% \text { ) of participants. Participants also } \\
\text { revealed institutional social and educational factors as } \\
\text { potential barriers in providing PC and integrating PC into } \\
\text { health systems. To overcome the barriers for integration } \\
\text { of PC into health systems, providing education for health } \\
\text { professionals and patient relatives, raising awareness in } \\
\text { society, financial arrangements and providing infrastructure } \\
\text { were suggested. }\end{array}$ \\
\hline
\end{tabular}


Supplementary Table 1. Details of the included studies. (Continued).

\begin{tabular}{|c|c|c|c|c|c|}
\hline $\begin{array}{l}\text { Oktay et al } \\
{[74]}\end{array}$ & English & Journal paper & Cross-sectional & $\begin{array}{l}\text { The perspectives of } \\
4,224 \text { medical students } \\
\text { on cancer, its treatment, } \\
\text { PC and the role of } \\
\text { oncologists. }\end{array}$ & $\begin{array}{l}\text { The result showed that oncology education among phase III } \\
\text { to VI students was useful for the students' understanding of } \\
\text { cancer, cancer screening and prevention. However, oncology } \\
\text { education to phase III to VI students failed to conceptualise } \\
\text { the true meaning of palliative/supportive care and student } \\
\text { thought that it was the oncologist's responsibility to treat } \\
\text { symptoms such as pain, nutrition and shortness of breath in } \\
\text { cancer patients. }\end{array}$ \\
\hline $\begin{array}{l}\text { Müller- } \\
\text { Schwefe et al } \\
\text { [280] }\end{array}$ & English & Journal paper & Cross-sectional & $\begin{array}{l}\text { Multinational survey } \\
\text { to understand the } \\
\text { perspective of patients } \\
\text { with chronic pain treated } \\
\text { with opioids on quality } \\
\text { of treatment, compliance } \\
\text { and communication } \\
\text { between patients and } \\
\text { physicians. }\end{array}$ & $\begin{array}{l}\text { Of the patients surveyed, } 61 \% \text { received strong opioids. } \\
\text { Nearly } 65 \% \text { of the patients were on a twice-daily or more } \\
\text { dosing schedule; however, } 61.5 \% \text { considered once-daily } \\
\text { dosing to be the most convenient schedule. Patients' } \\
\text { responses indicated that different dosing schedules } \\
\text { significantly influenced the occurrence of end-of-dose pain, } \\
\text { feeling limited by the remaining level of pain, problems in } \\
\text { falling asleep and episodes of waking up at night or early in } \\
\text { the morning. A total of } 556 \text { physicians also participated in the } \\
\text { survey. A majority of the physicians reported that they were } \\
\text { not surprised by the patients' responses regarding medication } \\
\text { and wanted to change some aspects of pain therapy such as } \\
\text { changing the medication, co-medication and non-medical } \\
\text { therapy. }\end{array}$ \\
\hline $\begin{array}{l}\text { Bar-Sela et al } \\
\text { [252] }\end{array}$ & English & Journal paper & Cross-sectional & $\begin{array}{l}\text { To examine the extent } \\
\text { of spiritual care provided } \\
\text { by staff and also staff } \\
\text { attitudes toward spiritual } \\
\text { care, including perceived } \\
\text { barriers. }\end{array}$ & $\begin{array}{l}\text { The survey was conducted among } 770 \text { physicians, and nurses } \\
\text { caring for patients with advanced cancer from } 14 \text { Middle East } \\
\text { countries. The } 168 \text { respondents were from Turkey. Nearly } \\
\text { one-half of the participants admitted that they would like } \\
\text { to provide spiritual care more often than they do. The most } \\
\text { commonly perceived barrier to care provision was insufficient } \\
\text { training and } 77 \% \text { of respondents lacked such training. The } \\
\text { single strongest predictor of not providing spiritual care was } \\
\text { not personally relating to spirituality. }\end{array}$ \\
\hline $\begin{array}{l}\text { Oğuz et al } \\
{[26]}\end{array}$ & English & Journal paper & Review & $\begin{array}{l}\text { This paper describes the } \\
\text { Palliative Care Unit in } \\
\text { an Oncology Hospital in } \\
\text { Ankara, Turkey. }\end{array}$ & $\begin{array}{l}\text { Ankara Oncology Education and Research Hospital was } \\
\text { founded in 1956. Initiative to PC approach began in } 1991 . \\
\text { The Palliative Care Unit was implemented in } 2007 . \text { This was } \\
\text { the first registered unit in Turkey. The PC team was consisting } \\
\text { of } 3 \text { pain specialist physicians, } 1 \text { anaesthesiologist, } 12 \text { nurses, } \\
1 \text { medical secretary and } 2 \text { helpers. Patients are accepted from } \\
\text { all universities, government or private hospitals. }\end{array}$ \\
\hline $\begin{array}{l}\text { Senel et al } \\
\text { [111] }\end{array}$ & English & Journal paper & Cross-sectional & $\begin{array}{l}\text { To determine the } \\
\text { frequency of delirium and } \\
\text { identify associated factors } \\
\text { at the PC of oncology } \\
\text { hospital. }\end{array}$ & $\begin{array}{l}\text { The incidence of delirium among the patients with cancer } \\
\text { was } 49.8 \% \text {. Subtypes of delirium included hypoactive } \\
49 \% \text {, mixed } 41 \% \text { and hyperactive } 10 \% \text {. The regression } \\
\text { analysis indicated that use of opioids, anticonvulsants, } \\
\text { benzodiazepines, steroids, infection, malnutrition, } \\
\text { immobilization, sleep disturbance, constipation, } \\
\text { hyperbilirubinaemia, liver/renal failure, hypoxia, electrolyte } \\
\text { imbalance, brain cancer/metastases were associated with } \\
\text { delirium. }\end{array}$ \\
\hline
\end{tabular}


Supplementary Table 1. Details of the included studies. (Continued).

\begin{tabular}{|c|c|c|c|c|c|}
\hline $\begin{array}{l}\text { Özalp et al } \\
\text { [100] }\end{array}$ & English & Journal paper & Cross-sectional & $\begin{array}{l}\text { To determine the } \\
\text { symptom clusters in } 170 \\
\text { inpatients at the palliative } \\
\text { care clinic of Oncology } \\
\text { Hospital. }\end{array}$ & $\begin{array}{l}\text { The most experienced symptoms by the patients during } \\
\text { the week before hospitalisation in palliative care clinic were } \\
\text { lack of energy ( } 95.4 \%) \text {, weight loss }(91.2 \%) \text {, lack of appetite } \\
\text { (89.4\%), pain ( } 88.2 \%) \text {, dry mouth ( } 87.6 \%) \text {, feeling sad ( } 87.6 \%) \text {, } \\
\text { feeling nervous ( } 82.9 \%) \text {, worrying ( } 81.2 \%) \text { and feeling } \\
\text { irritable (80.6\%). The Five symptom clusters identified were; } \\
\text { First cluster: pain, feeling nervous, dry mouth, worrying, } \\
\text { feeling irritable, weight loss; second cluster: feeling drowsy, } \\
\text { numbness/tingling in hands/feet, difficulty in sleeping, } \\
\text { dizziness, constipation, I do not look like myself; third } \\
\text { cluster: nausea, vomiting; fourth cluster: shortness of breath, } \\
\text { difficulty in swallowing, cough, change in the way food tastes } \\
\text { and fifth cluster: feeling bloated, problems with urination, } \\
\text { diarrhoea, itching, mouth sores, hair loss, swelling of arm or } \\
\text { legs, change in the skin. }\end{array}$ \\
\hline $\begin{array}{l}\text { Ozcelik et al } \\
\text { [116] }\end{array}$ & English & Journal paper & Interventional & $\begin{array}{l}\text { It was aimed to } \\
\text { investigate the } \\
\text { improvement in } \\
\text { symptoms, quality of } \\
\text { life, patient and family } \\
\text { satisfaction with care, and } \\
\text { direct costs resulting from } \\
\text { a PC intervention-based } \\
\text { case management model. }\end{array}$ & $\begin{array}{l}\text { The level of decrease in symptom severity in the } \\
\text { experimental group patients (PC intervention-based case } \\
\text { management model) was more than in the control group } \\
\text { (conventional care). The satisfaction level of patients and } \\
\text { families in the PC-based case management service was } \\
\text { higher than that for conventional service in the control } \\
\text { group. No statistical difference was detected between the } \\
\text { experimental and control groups regarding health costs and } \\
\text { duration of hospitalisation. }\end{array}$ \\
\hline $\begin{array}{l}\text { Akyar et al } \\
\text { [281] }\end{array}$ & English & Journal paper & Review & $\begin{array}{l}\text { This review article } \\
\text { describes an early PC } \\
\text { telehealth delivery models } \\
\text { 'Nurture, Advice, Before } \\
\text { Life Ends (ENABLE)'. }\end{array}$ & $\begin{array}{l}\text { ENABLE is a collaborative approach to the care of patients } \\
\text { and caregivers, focusing on self-care management and } \\
\text { skills training to empower patients to actively participate } \\
\text { and make informed choices about treatment issues. It has } \\
\text { demonstrated effectiveness in improving quality of life, } \\
\text { symptom relief and survival for patients with cancer in the } \\
\text { USA. The authors identified it as a good model to develop PC } \\
\text { in Turkey. To improve the effectiveness a culturally sensitive } \\
\text { model ENABLE-TR was developed for supportive care } \\
\text { coaching to Turkish caregivers of advanced cancer patients. }\end{array}$ \\
\hline $\begin{array}{l}\text { Vranken et al } \\
\text { [122] }\end{array}$ & English & Journal paper & Review & $\begin{array}{l}\text { To identify legal and } \\
\text { regulatory barriers to } \\
\text { opioid access in European } \\
\text { countries (including } \\
\text { Turkey). }\end{array}$ & $\begin{array}{l}\text { Across all } 11 \text { countries, } 778 \text { potential barriers (excluding } \\
\text { the language category) were identified. Other than the } \\
\text { language category, Turkey had shown more than } 40 \text { potential } \\
\text { barriers in the following categories; prescribing, dispensing, } \\
\text { Usage, trade and distribution, manufacturing, penalties, } \\
\text { other (medical activities restricted, violation of privacy, other } \\
\text { administrative requirements, limited access to education. } \\
\text { The Potential barriers in the legislation and regulations were } \\
\text { unclear definition of controlled medicines in its use Turkey. }\end{array}$ \\
\hline
\end{tabular}


Supplementary Table 1. Details of the included studies. (Continued).

\begin{tabular}{|c|c|c|c|c|c|}
\hline $\begin{array}{l}\text { Dincer et al } \\
\text { [85] }\end{array}$ & English & Journal paper & $\begin{array}{l}\text { Retrospective/ } \\
\text { cross-sectional }\end{array}$ & $\begin{array}{l}\text { To evaluate the factors } \\
\text { affecting the length of } \\
\text { stay (LOS) and discharge } \\
\text { of } 435 \text { patients from a PC } \\
\text { centres (PCC) of a State } \\
\text { Hospital. }\end{array}$ & $\begin{array}{l}\text { The mean LOS was } 27.2 \pm 30.9 \text { days. The mean Glasgow } \\
\text { Coma Scale GCS was } 11.3 \pm 3.3 \text {, Karnofsky Performance } \\
\text { Scale KPS was } 39.6 \pm 14.4 \text {, mortality was } 46.2 \% \text { in PCC. } \\
\text { The most commonly seen diagnoses and comorbidities } \\
\text { were hypertension } 47.1 \% \text {, cancer } 38.4 \% \text {, cerebrovascular } \\
\text { event } 25.7 \% \text { and diabetes mellitus } 22.3 \% \text {. Percutaneous } \\
\text { Endoscopic Gastrostomy (PEG) was applied to } 29.4 \% \text { of } \\
\text { patients, tracheostomy to } 19.8 \% \text { and mechanical ventilator } \\
\text { support to } 5.5 \% \text { of patients. In the regression analysis, the } \\
\text { comorbidities (hypertension, pressure injury), PEG, total } \\
\text { parenteral nutrition and infection were found to increase } \\
\text { LOS in PCC. }\end{array}$ \\
\hline $\begin{array}{l}\text { Eyigor and } \\
\text { Akdeniz [59] }\end{array}$ & English & Journal paper & Review & $\begin{array}{l}\text { This review article } \\
\text { describes the importance } \\
\text { of physical activity in PC } \\
\text { programmes for cancer } \\
\text { patients. }\end{array}$ & $\begin{array}{l}\text { Exercise and rehabilitation approaches in PC programmes } \\
\text { for cancer patients affect patients' symptoms, physical } \\
\text { functioning, muscle strength, emotional well-being, } \\
\text { psychological symptoms, functional capacities, quality of } \\
\text { life, mortality and morbidity positively. Based on scientific } \\
\text { data, palliative cancer patients should be recommended to } \\
\text { participate in exercise programmes. }\end{array}$ \\
\hline $\begin{array}{l}\text { Tanriverdi } \\
\text { et al [81] }\end{array}$ & English & Journal paper & Cross-sectional & $\begin{array}{l}\text { The perspective of non- } \\
\text { oncologist physicians } \\
\text { regarding their attitudes } \\
\text { and beliefs associated } \\
\text { with PC for patients with } \\
\text { metastatic cancer. }\end{array}$ & $\begin{array}{l}\text { A total of } 71 \% \text { of participants identified all patients with } \\
\text { metastatic cancer as being a terminal stage, } 62 \% \text { were } \\
\text { unaware of PC techniques, } 64 \% \text { did not know about common } \\
\text { supportive care options, } 59 \% \text { were against hospice and } 63 \% \\
\text { had no opinion on resuscitation. It was found that non- } \\
\text { oncologist physicians believed that palliative/supportive care } \\
\text { is the oncologist's task. }\end{array}$ \\
\hline $\begin{array}{l}\text { Çiraci et al } \\
{[104]}\end{array}$ & English & Journal paper & Cross sectional & $\begin{array}{l}\text { To evaluate the } \\
\text { feeling of loneliness in } \\
\text { terminal cancer patients } \\
\text { hospitalised for palliative } \\
\text { therapy. }\end{array}$ & $\begin{array}{l}\text { The mean level of loneliness was } 53.61 \pm 9.29 \text {. Analysis of } \\
\text { the loneliness level according to patient information revealed } \\
\text { that the group of patients aged } 29-39 \text {, males, literate } \\
\text { patients and single/widows experienced higher levels of } \\
\text { loneliness. }\end{array}$ \\
\hline $\begin{array}{l}\text { Bülbül et al } \\
\text { [96] }\end{array}$ & English & Journal paper & Cross-sectional & $\begin{array}{l}\text { To analyse the impact } \\
\text { of cancer symptoms } \\
\text { on insomnia and the } \\
\text { prevalence of sleep- } \\
\text { related problems reported } \\
\text { by } 1,245 \text { patients } \\
\text { with lung cancer in } 26 \\
\text { hospitals in Turkey. }\end{array}$ & $\begin{array}{l}\text { The prevalence of insomnia was } 44.7 \% \text {. Among all cases, } \\
48.4 \% \text { reported difficulty initiating or maintaining sleep, } \\
60.8 \% \text { reported daytime sleepiness and } 82.1 \% \text { reported } \\
\text { fatigue. Female gender, patients with stage } 3-4 \text { disease, } \\
\text { patients with metastases, with comorbidities and with weight } \\
\text { loss }>5 \mathrm{~kg} \text { had higher rates of insomnia. Also, patients with } \\
\text { insomnia had significantly higher rates of pain, nausea, } \\
\text { dyspnoea and anxiety. }\end{array}$ \\
\hline Can [20] & English & Journal paper & Review & $\begin{array}{l}\text { This review describes the } \\
\text { scope of PC nursing in } \\
\text { Turkey. }\end{array}$ & $\begin{array}{l}\text { PC nursing is not recognised as a nursing speciality in } \\
\text { Turkey. There was no curriculum, graduate/postgraduate } \\
\text { programmes, for nurses on PC in and the scope of the PC } \\
\text { nursing education varies among universities. }\end{array}$ \\
\hline
\end{tabular}


Supplementary Table 1. Details of the included studies. (Continued).

\begin{tabular}{|c|c|c|c|c|c|}
\hline $\begin{array}{l}\text { Terzioglu et al } \\
\text { [53] }\end{array}$ & English & Journal paper & Review & $\begin{array}{l}\text { This review provides } \\
\text { Turkish Nurses' } \\
\text { Perspectives on Palliative } \\
\text { Care to the Cancer } \\
\text { Patient in Turkey. }\end{array}$ & $\begin{array}{l}\text { The lack of PC education and training opportunities is } \\
\text { the most frequently reported barrier to the development } \\
\text { of PC in Turkey. PC education has not been integrated } \\
\text { into the curriculum of nursing at both undergraduate and } \\
\text { postgraduate levels. Nurses acquire his/her PC knowledge } \\
\text { and skills after graduation, from programmes with different } \\
\text { formats such as workshops, seminars and courses. }\end{array}$ \\
\hline Gurhan [24] & English & Journal paper & Review & $\begin{array}{l}\text { This paper discussed the } \\
\text { history and current status } \\
\text { of PC in Turkey. }\end{array}$ & $\begin{array}{l}\text { The first institution that provided long-standing PC was } \\
\text { 'Cancer Care Centres' established by the Turkish Oncology } \\
\text { Foundation in Yeşilköy İstanbul. These centres provided } \\
\text { service between } 1993 \text { and } 1997 \text {. However, services were } \\
\text { not reimbursed within the social security system. In } 2006 \text {. } \\
\text { 'Hacettepe Hope House' was founded to provide a minimal } \\
\text { nursing and accommodation service to patients with cancer } \\
\text { for a few weeks during their treatment and the following } \\
\text { period. The first PC unit, and 'Palliative Care Practice and } \\
\text { Research Centre' was established in Ege University. By } \\
\text { January } 2016 \text {, there were } 148 \text { palliatives care centres that } \\
\text { provide services with a registered bed capacity of } 1,672 \text { in } 29 \\
\text { Healthcare Regions. }\end{array}$ \\
\hline $\begin{array}{l}\text { Guzelant et al } \\
\text { [92] }\end{array}$ & English & Journal paper & Tool validation & $\begin{array}{l}\text { To evaluate the validity } \\
\text { and reliability of the } \\
\text { Turkish version of the } \\
\text { European Organization } \\
\text { for Research and } \\
\text { Treatment of Cancer } \\
\text { Quality of Life Core } \\
\text { Questionnaire version } 2.0 \\
\text { (EORTC QLQ-C30). }\end{array}$ & $\begin{array}{l}\text { The EORTC QLQ-C30 is a valid and reliable instrument } \\
\text { for Turkish lung cancer patients and can be used in clinical } \\
\text { studies but needs supporting by the reference data on the } \\
\text { Quality of Life of the Turkish population. }\end{array}$ \\
\hline Eyigor [60] & English & Journal paper & Review & $\begin{array}{l}\text { In this review effects of } \\
\text { exercise in PC for cancer } \\
\text { patients. }\end{array}$ & $\begin{array}{l}\text { Fatigue is one of the most frequent symptoms in PC patients. } \\
\text { And it is associated with anxiety-depression, pain, dyspnoea, } \\
\text { insomnia, anorexia, nausea and drowsiness that reduces } \\
\text { daily activities and affects Quality of Life (QoL) of patients. } \\
\text { Physical therapy and rehabilitation practices can have a } \\
\text { positive impact on symptoms, functional capacity and QoL. }\end{array}$ \\
\hline Isikhan [282] & English & Journal paper & Review & $\begin{array}{l}\text { In this review, coping } \\
\text { strategies used by } \\
\text { advanced cancer patients } \\
\text { were described. }\end{array}$ & $\begin{array}{l}\text { Cancer persons report using more avoidant coping } \\
\text { strategies such as escape/avoidance denial or behavioural } \\
\text { disengagement. The use of such strategies is associated with } \\
\text { increased psychological distress and may be a risk factor for } \\
\text { adverse responses to illness. PC staff who are may identify } \\
\text { the need for support and assistance with coping strategies. }\end{array}$ \\
\hline $\begin{array}{l}\text { Yeşilbalkan } \\
\text { et al [94] }\end{array}$ & English & Journal paper & Tool validation & $\begin{array}{l}\text { To test the validity } \\
\text { and reliability of the } \\
\text { Edmonton Symptom } \\
\text { Assessment Scale for } \\
\text { Turkish cancer patients. }\end{array}$ & $\begin{array}{l}\text { The Turkish version of the Edmonton Symptom Assessment } \\
\text { Scale was determined to be a valid and reliable tool for use in } \\
\text { Turkish individuals with cancer. }\end{array}$ \\
\hline
\end{tabular}


Supplementary Table 1. Details of the included studies. (Continued).

\begin{tabular}{|c|c|c|c|c|c|}
\hline Yildirim [99] & English & Journal paper & Tool validation & $\begin{array}{l}\text { To evaluate its reliability } \\
\text { and validity of the } \\
\text { Memorial Symptom } \\
\text { Assessment Scale. }\end{array}$ & $\begin{array}{l}\text { The Memorial Symptom Assessment Scale is a reliable and } \\
\text { valid instrument for the use in the Turkish cancer patients } \\
\text { for comprehensive symptom assessment in planning nursing } \\
\text { care. }\end{array}$ \\
\hline $\begin{array}{l}\text { Sahin and Tan } \\
\text { [103] }\end{array}$ & English & Journal paper & Cross-sectional & $\begin{array}{l}\text { To determine whether } \\
\text { Turkish patients with } \\
\text { cancer and their } \\
\text { caregivers differed in } \\
\text { feelings of loneliness and } \\
\text { depression. }\end{array}$ & $\begin{array}{l}\text { This study enrolled } 60 \text { caregivers and } 60 \text { cancer patients } \\
\text { admitted at the Oncology and Hematology Department of } \\
\text { a Teaching Hospital. } 70 \% \text { of patients and } 63 \% \text { of caregivers } \\
\text { reported a high level of loneliness. The average loneliness } \\
\text { score for patients was more than caregivers' scores. Serious } \\
\text { depressive symptoms were experienced by } 57 \% \text { of patients } \\
\text { and } 71 \% \text { of caregivers. Levels of perceived social support } \\
\text { from family differed between patients and caregivers. Both } \\
\text { groups showed a strong inverse relationship existed between } \\
\text { depression, loneliness and perceived social support from } \\
\text { family. }\end{array}$ \\
\hline $\begin{array}{l}\text { Akyar et al } \\
\text { [84] }\end{array}$ & English & Journal paper & $\begin{array}{l}\text { Qualitative/ } \\
\text { semi- } \\
\text { structured } \\
\text { interviews }\end{array}$ & $\begin{array}{l}\text { Adaptation of the } \\
\text { ENABLE (Educate, } \\
\text { Nurture, Advise, Before } \\
\text { Life Ends) evidence-based } \\
\text { early PC model for Turkish } \\
\text { family caregivers of } \\
\text { cancer patients. }\end{array}$ & $\begin{array}{l}\text { Semi-structured interviews were conducted with } 25 \text { primary } \\
\text { family caregivers. The caregivers described the impact of } \\
\text { cancer on their daily lives and responsibilities in the areas of } \\
\text { physical, psychological, work, social and family life. Caregivers } \\
\text { emphasised their needs for information about symptoms, } \\
\text { physical care, cancer pathology and prognosis. Regarding the } \\
\text { ENABLE model of early concurrent PC, participants wanted } \\
\text { in-person training with educational material that should be } \\
\text { simple and focused on disease information, psychological } \\
\text { support, caring, nutrition and acquiring community services. }\end{array}$ \\
\hline $\begin{array}{l}\text { Kabalak et al } \\
\text { [23] }\end{array}$ & English & Journal paper & Review & $\begin{array}{l}\text { This article reports the } \\
\text { structure and function of } \\
\text { 'Comprehensive Palliative } \\
\text { Care Center' in the State } \\
\text { Hospital. }\end{array}$ & $\begin{array}{l}\text { The multidisciplinary team is involved in patient } \\
\text { management. There is room for training, physical activity and } \\
\text { recreation activities. For spiritual care, preachers discuss the } \\
\text { philosophy of Islam on life and death issues. The home care } \\
\text { team visits discharged patients to record the vitals, wound } \\
\text { care, nutrition and ventilation support. Due to the ambiguity } \\
\text { of policies regarding PC, a 'Long Term Intensive Care Units' is } \\
\text { also opened in the hospital. }\end{array}$ \\
\hline $\begin{array}{l}\text { Yildirim et al } \\
\text { [70] }\end{array}$ & English & Journal paper & Cross-sectional & $\begin{array}{l}\text { To examine information } \\
\text { about the knowledge } \\
\text { and attitudes of Turkish } \\
\text { oncology nurses regarding } \\
\text { cancer pain management. }\end{array}$ & $\begin{array}{l}\text { Of the } 68 \text { oncology nurses, only } 35.5 \% \text { responded correctly } \\
\text { regarding cancer pain management. The nurses' pain } \\
\text { management knowledge was positively correlated to the } \\
\text { length of working experience in the oncology unit. }\end{array}$ \\
\hline $\begin{array}{l}\text { Ozveren and } \\
\text { Kirca [254] }\end{array}$ & English & Journal paper & Cross-sectional & $\begin{array}{l}\text { To determine the } \\
\text { influence of PC training } \\
\text { on the perception levels } \\
\text { of nurses regarding } \\
\text { spiritual care. }\end{array}$ & $\begin{array}{l}55.7 \% \text { of the nursing students stated that they had never } \\
\text { heard of spiritual care, and } 81.4 \% \text { had not obtained any } \\
\text { information regarding spiritual care. The point average of } \\
\text { pretest-posttest intervention using spirituality and spiritual } \\
\text { care grading scale found that the perception of the student } \\
\text { regarding spirituality and spiritual support was increased } \\
\text { significantly after the training. }\end{array}$ \\
\hline
\end{tabular}


Supplementary Table 1. Details of the included studies. (Continued).

\begin{tabular}{|c|c|c|c|c|c|}
\hline $\begin{array}{l}\text { Okan et al } \\
{[255]}\end{array}$ & English & Journal paper & Cross-sectional & $\begin{array}{l}\text { To investigate whether a } \\
\text { cultural mourning ritual, } \\
\text { the 'First Feast', can be } \\
\text { used by PC teams to } \\
\text { ease the grief response } \\
\text { of the deceased patient's } \\
\text { relatives. }\end{array}$ & $\begin{array}{l}\text { The study included } 427 \text { relatives of PC patients in Tokat } \\
\text { province. A total of } 76.8 \% \text { participants were from the Tokat } \\
\text { and } 77.8 \% \text { performed the First Feast tradition. About } 91 \% \text { of } \\
\text { the participants acknowledged that the tradition helped to } \\
\text { ease the grief response of the relatives and might be a useful } \\
\text { auxiliary method for PC teams to help grieving families. }\end{array}$ \\
\hline $\begin{array}{l}\text { Metin and } \\
\text { Demirci [259] }\end{array}$ & English & Journal paper & Cross-sectional & $\begin{array}{l}\text { This study aimed to } \\
\text { investigate the effect } \\
\text { of health literacy }(\mathrm{HL}) \\
\text { of the caregiver on the } \\
\text { care results, including } \\
\text { mortality, of } 240 \mathrm{PC} \\
\text { patients. }\end{array}$ & $\begin{array}{l}\text { About } 19.50 \% \text { of the patient caregivers had adequate HL } \\
\text { using the Health Literacy Survey - Europe Union. Caregivers } \\
\text { had difficulty to access information of what to do in case of } \\
\text { emergency. Prevalence of bedsore occurrence in patients } \\
\text { whose caregiver has 'inadequate' HL is higher than patients } \\
\text { whose caregiver has 'adequate' HL. Prevalence of 'inadequate } \\
\mathrm{HL} \text { ' of the caregiver was higher among patient who died with- } \\
\text { in } 3 \text { months after inclusion in the study. }\end{array}$ \\
\hline $\begin{array}{l}\text { Dagli et al } \\
\text { [206] }\end{array}$ & English & Journal paper & Cost analysis & $\begin{array}{l}\text { To evaluate the } \\
\text { nosocomial infections } \\
\text { and to understand factors } \\
\text { affecting the cost of used } \\
\text { antibiotics among } 113 \\
\text { patients in the PC unit of } \\
\text { the Hospital. }\end{array}$ & $\begin{array}{l}\text { Nosocomial infections were observed among } 74.3 \% \text { of the } \\
\text { cases, antibiotics were used in } 92.0 \% \text { of patients. The mean } \\
\text { duration of antibiotic use was } 23.13 \pm 18.06 \text { days, and the } \\
\text { average antibiotic cost was } 2,009.72 \pm 2,153.37 \text { TL. Length } \\
\text { of stay, male sex, presence of decubitus ulcers, tracheostomy, } \\
\text { enteral and parenteral nutrition significantly increased } \\
\text { antibiotic cost. Antibiotic cost and mortality were found } \\
\text { unrelated. }\end{array}$ \\
\hline $\begin{array}{l}\text { Bar-Sela et al } \\
\text { [283] }\end{array}$ & English & Journal paper & Cross-sectional & $\begin{array}{l}\text { To study the attitudes } \\
\text { of oncology nurses } \\
\text { and physicians toward } \\
\text { spiritual care provision, in } \\
\text { relation to Middle Eastern } \\
\text { culture and Human } \\
\text { Development Index. }\end{array}$ & $\begin{array}{l}773 \text { responses from } 14 \text { countries were analysed (168 from } \\
\text { Turkey). Over } 63 \% \text { of respondents positively viewed items } \\
\text { such as spiritual history taking, referrals and encouraging } \\
\text { patients in their spirituality. While significantly more, } \\
\text { over } 76 \% \text {, did so among respondents from very high HDI } \\
\text { countries. Only } 42 \%-45 \% \text { overall were positively inclined } \\
\text { toward praying with patients. Overall respondents in lower } \\
\text { HDI countries expressed significantly more positive views. }\end{array}$ \\
\hline $\begin{array}{l}\text { Bagcivan et al } \\
{[112]}\end{array}$ & English & Journal paper & Tool validation & $\begin{array}{l}\text { To determine the } \\
\text { psychometric properties } \\
\text { of the newly translated } \\
\text { Functional Assessment of } \\
\text { Chronic Illness Therapy } \\
\text { Palliative Care (FACIT-Pal) } \\
\text { scale for Turkish-speaking } \\
\text { cancer patients-FACIT- } \\
\text { Pal-TR. }\end{array}$ & $\begin{array}{l}\text { The FACIT-Pal-TR demonstrates strong reliability and validity } \\
\text { for evaluating PC specific QoL in Turkish cancer patients. }\end{array}$ \\
\hline $\begin{array}{l}\text { Saygili and } \\
\text { Celik [207] }\end{array}$ & English & Journal paper & Cost analysis & $\begin{array}{l}\text { To evaluate the cost- } \\
\text { effectiveness of three PC } \\
\text { models }\end{array}$ & $\begin{array}{l}\text { Three alternative PC models, namely; Comprehensive } \\
\text { Palliative Care Center (CPCC), hospital inpatient services } \\
\text { (HIS) and home healthcare (HHC) for cancer patients were } \\
\text { analysed. From a societal perspective, PC services provided } \\
\text { by the HIS model was found to be more cost-effective than } \\
\text { the CPCC model. From a patient perspective, HHC was found } \\
\text { to be more cost-effective compared to the other two models. }\end{array}$ \\
\hline
\end{tabular}


Supplementary Table 1. Details of the included studies. (Continued).

\begin{tabular}{|c|c|c|c|c|c|}
\hline $\begin{array}{l}\text { Yildiz et al } \\
\text { [113] }\end{array}$ & English & Journal paper & Tool validation & $\begin{array}{l}\text { To determine the validity } \\
\text { and reliability of the } \\
\text { Karnofsky Performance } \\
\text { Scale (KPS) in cancer } \\
\text { patients receiving PC. }\end{array}$ & $\begin{array}{l}\text { KPS is a reliable scale for Turkish cancer patients in PC } \\
\text { settings. }\end{array}$ \\
\hline $\begin{array}{l}\text { Akdeniz et al } \\
{[75]}\end{array}$ & English & Journal paper & Interventional & $\begin{array}{l}\text { Effect of web-based } \\
\text { paediatric PC education } \\
\text { on nursing students' } \\
\text { knowledge level and } \\
\text { practices. }\end{array}$ & $\begin{array}{l}\text { A statistically significant difference was observed between } \\
\text { the pretest and posttest scores of the students given web- } \\
\text { based paediatric PC education (intervention group) and the } \\
\text { control groups regarding the PC knowledge level and self- } \\
\text { reported PC practices. }\end{array}$ \\
\hline $\begin{array}{l}\text { Temelli and } \\
\text { Cerit [253] }\end{array}$ & English & Journal paper & $\begin{array}{l}\text { Qualitative/ } \\
\text { interviews }\end{array}$ & $\begin{array}{l}\text { Interviews with PC } \\
\text { nurses to identifying } \\
\text { their perceptions about } \\
\text { death and determining PC } \\
\text { practices. }\end{array}$ & $\begin{array}{l}\text { The palliative nurses had empathy when they met death } \\
\text { in the unit where they worked. They perceive death as a } \\
\text { natural and inevitable process and that as long as their } \\
\text { working period increases, they become desensitised. They } \\
\text { thought that death was a salvation for the patient. The nurses } \\
\text { performed PC self-care needs, pain relief, prevention and } \\
\text { management of pressure wounds. }\end{array}$ \\
\hline $\begin{array}{l}\text { Özdemir et al } \\
\text { [258] }\end{array}$ & English & Journal paper & Cross-sectional & $\begin{array}{l}\text { Psychosocial problems } \\
\text { and spiritual coping } \\
\text { styles of the } 78 \text { family } \\
\text { caregivers of patients } \\
\text { receiving PC. }\end{array}$ & $\begin{array}{l}\text { The mean anxiety and depression scores using the Hospital } \\
\text { Anxiety Depression Scale were } 10.86 \pm 4.30 \text { and } 9.38 \pm \\
3.66 \text {, respectively. The mean positive and negative results of } \\
\text { the Religious Coping Methods Scale were } 25.31 \pm 3.85 \text { and } \\
10.32 \pm 3.38 \text {, respectively. }\end{array}$ \\
\hline $\begin{array}{l}\text { Kocatepe et al } \\
\text { [114] }\end{array}$ & English & Journal paper & Tool validation & $\begin{array}{l}\text { To examine the validity } \\
\text { and reliability of the } \\
\text { Turkish version of the } \\
\text { Palliative Care Outcome } \\
\text { Scale (POS). }\end{array}$ & $\begin{array}{l}\text { The Turkish version of the POS a valid and reliable tool to be } \\
\text { used for assessing the needs of PC patients. The Cronbach's } \\
\text { alpha reliability coefficients were determined as } 0.64 \text { for the } \\
\text { patient questionnaire, } 0.73 \text { for the carer questionnaire and } \\
0.68 \text { for the staff questionnaire. }\end{array}$ \\
\hline $\begin{array}{l}\text { Tertemiz and } \\
\text { Tuyluoglu [87] }\end{array}$ & English & Journal paper & Cross-sectional & $\begin{array}{l}\text { To reveal the differences } \\
\text { in the signs of burnout } \\
\text { and stress between } \\
\text { PC workers and those } \\
\text { working in neurology and } \\
\text { internal disease clinics. }\end{array}$ & $\begin{array}{l}\text { Emotional burnout and desensitisation scores were found } \\
\text { to be elevated, and personal success scores were low } \\
\text { in both groups. The Beck Anxiety Inventory revealed } \\
\text { moderate anxiety in both groups, while cognitive-sensorial, } \\
\text { physiological and pain complaints, as well as signs of stress, } \\
\text { were more pronounced among workers in internal disease } \\
\text { and neurology clinics. }\end{array}$ \\
\hline $\begin{array}{l}\text { Clark et al } \\
\text { [35] }\end{array}$ & English & Journal paper & Survey & $\begin{array}{l}\text { The objective of this } \\
\text { study was to describe } \\
\text { current levels of global PC } \\
\text { development and report } \\
\text { on changes since } 2006 \text {. }\end{array}$ & $\begin{array}{l}\text { Based on the survey indicators the status of PC in Turkey was } \\
\text { as follows: } \\
\text { 2006; Category 2: Capacity-building PC activity } \\
\text { 2011; Category 3b: Generalised PC provision } \\
\text { 2017; Category 3a: Isolated PC provision }\end{array}$ \\
\hline $\begin{array}{l}\text { Arias-Casais } \\
\text { et al [136] }\end{array}$ & English & Journal paper & Survey & $\begin{array}{l}\text { To conduct the first } \\
\text { regional assessment } \\
\text { of paediatric PC } \\
\text { development and } \\
\text { Provision. }\end{array}$ & $\begin{array}{l}\text { Number of providing Paediatric Palliative Care service PPC } \\
\text { identified in Turkey in } 2019 \text { were as follows: } \\
\text { Hospices services }=01 \\
\text { Home-care services }=00 \\
\text { Hospital services }=04\end{array}$ \\
\hline
\end{tabular}


Supplementary Table 1. Details of the included studies. (Continued).

\begin{tabular}{|c|c|c|c|c|c|}
\hline $\begin{array}{l}\text { Yalcin et al } \\
\text { [284] }\end{array}$ & English & Journal paper & $\begin{array}{l}\text { Qualitative/ } \\
\text { expert panel }\end{array}$ & $\begin{array}{l}\text { Statement by a panel } \\
\text { of medical oncologists } \\
\text { to provide guidance } \\
\text { addressing nutritional } \\
\text { aspects of cancer care. }\end{array}$ & $\begin{array}{l}\text { Participating experts agreed on the use of liquid and high } \\
\text { energy-dense oral nutritional supplements to enable better } \\
\text { patient compliance, improved lean body mass, functional } \\
\text { status and quality of life, as well as better tolerance to } \\
\text { antineoplastic treatment. }\end{array}$ \\
\hline $\begin{array}{l}\text { Irmak et al } \\
\text { [90] }\end{array}$ & English & Journal paper & Cross-sectional & $\begin{array}{l}\text { Frequency of } \\
\text { complementary and } \\
\text { alternative medicine } \\
\text { (CAM) therapies among } \\
\text { cancer patients and to } \\
\text { evaluate their quality of } \\
\text { life. }\end{array}$ & $\begin{array}{l}\text { Among } 211 \text { patients, } 46.4 \% \text { were CAM users. The most } \\
\text { commonly used CAM therapy was herbal products. The } \\
\text { rate of CAM use was higher among the patients with a low } \\
\text { education level. No statistically significant difference was } \\
\text { found between the quality-of-life scores of the CAM user } \\
\text { and non-user patients. }\end{array}$ \\
\hline $\begin{array}{l}\text { Ozdemir et al } \\
\text { [139] }\end{array}$ & English & Journal paper & $\begin{array}{l}\text { Retrospective / } \\
\text { cross-sectional }\end{array}$ & $\begin{array}{l}\text { The role and contribution } \\
\text { of hospital-based home } \\
\text { health services regarding } \\
\text { the respiratory illness. }\end{array}$ & $\begin{array}{l}\text { The MoH data concerning HHS for respiratory diseases } \\
\text { between } 2011 \text { and } 2017 \text { showed that the number of house } \\
\text { visits concerning pulmonary disorders (COPD, lung cancer) } \\
\text { increased nearly ten times, but hospitalisation due to } \\
\text { respiratory diseases decreased ( } 13.5 \% \text { in } 2011 \text { to } 12.9 \% \text { in } \\
\text { 2017). }\end{array}$ \\
\hline $\begin{array}{l}\text { Sarıcam et al } \\
\text { [86] }\end{array}$ & English & Journal paper & $\begin{array}{l}\text { Retrospective / } \\
\text { Cross-sectional }\end{array}$ & $\begin{array}{l}\text { Prevalence of neurological } \\
\text { symptoms in cancer } \\
\text { patients followed up in a } \\
\text { PC centre. }\end{array}$ & $\begin{array}{l}\text { The most common neurological symptoms were pain, } \\
\text { insomnia, delirium, seizures, depression and paresis ( } 27.1 \% \text {, } \\
17.2 \%, 15.1 \%, 13.5 \%, 11.5 \%) \text {, respectively. The pain was } \\
\text { most commonly observed in genitourinary and gynaecologic } \\
\text { cancers ( } 72.4 \% \text { ) and gastrointestinal cancers ( } 69.3 \%) \text {. Paresis } \\
\text { and seizures were significantly higher in patients with head } \\
\text { and neck cancers. }\end{array}$ \\
\hline $\begin{array}{l}\text { Baykara et al } \\
\text { [220] }\end{array}$ & English & Journal paper & Cross-sectional & $\begin{array}{l}\text { The opinions and } \\
\text { attitudes of intensive } \\
\text { care unit (ICU) physicians } \\
\text { regarding End of Life (EoL) } \\
\text { decisions, for both their } \\
\text { patients and themselves. }\end{array}$ & $\begin{array}{l}\text { Religious beliefs had no effect on the physicians' acceptance } \\
\text { of do-not-resuscitate (DNR)/do-not-intubate (DNI) orders } \\
\text { for terminally ill patients. The medical experience and } \\
\text { proportion of terminally ill patients in the ICU appears to } \\
\text { affect physicians' attitudes to EOL decisions. The younger } \\
\text { physicians ( } 30-39 \text { years) were more likely to prefer the 'only } \\
\text { DNR' option compared with physicians aged } 40-49 \text { years for } \\
\text { themselves. }\end{array}$ \\
\hline $\begin{array}{l}\text { Centeno et al } \\
\text { [133] }\end{array}$ & English & Journal paper & $\begin{array}{l}\text { Mixed method; } \\
\text { literature } \\
\text { review, } \\
\text { qualitative and } \\
\text { quantitative } \\
\text { survey }\end{array}$ & $\begin{array}{l}\text { Facts and indicators on } \\
\text { PC development in } 52 \\
\text { countries of the WHO } \\
\text { European region. }\end{array}$ & $\begin{array}{l}\text { Provision of specific PC services were } 0.3 \text { /million population. } \\
\text { The development of paediatric PC specific resources was at } \\
\text { level } 1 \text { (unspecific resources). The provision of specialist PC } \\
\text { beds was } 241 \text { and there was no PC physicians working full } \\
\text { time. }\end{array}$ \\
\hline $\begin{array}{l}\text { Guclu et al } \\
\text { [221] }\end{array}$ & English & Journal paper & Cross-sectional & $\begin{array}{l}\text { Symptoms of depression } \\
\text { and anxiety of caregivers } \\
\text { of patients hospitalised in } \\
\text { the extensive PC centre. }\end{array}$ & $\begin{array}{l}\text { The risk of depression was identified as } 43 \% \text { according to } \\
\text { the Beck anxiety scale (BAS), and as } 91 \% \text { according to the } \\
\text { hospital anxiety and depression scale (HADS). The anxiety } \\
\text { rate was } 66 \% \text { according to the BAS. Among these, } 36 \% \\
\text { demonstrated mild anxiety, } 30 \% \text { demonstrated moderate } \\
\text { anxiety and } 32 \% \text { demonstrated severe anxiety. According to } \\
\text { HADS, the risk for anxiety was } 72 \% \text {. }\end{array}$ \\
\hline
\end{tabular}


Supplementary Table 1. Details of the included studies. (Continued).

\begin{tabular}{|c|c|c|c|c|c|}
\hline $\begin{array}{l}\text { Turkoglu and } \\
\text { Kilic [238] }\end{array}$ & English & Journal paper & Cross-sectional & $\begin{array}{l}\text { The effects of caring } \\
\text { burden of family } \\
\text { caregivers of cancer } \\
\text { patients on their quality of } \\
\text { life in the East of Turkey. }\end{array}$ & $\begin{array}{l}\text { The mean score of the burden of caregivers was } 36.6 \pm 11.2 \\
\text { and their mean score of Caregiver Quality of Life Index- } \\
\text { Cancer was } 81.4 \pm 17.3 \text {. There was a negative relationship } \\
\text { between caring burdens and the quality of life ( } p<0.001 \text { ). } \\
\text { Descriptive characteristics, caring-related properties and } \\
\text { caring burden variables were all significant predictors of the } \\
\text { quality of life. The caregivers should take support by training } \\
\text { about providing care. }\end{array}$ \\
\hline $\begin{array}{l}\text { Vardar Yağlı } \\
\text { et al [62] }\end{array}$ & English & Journal paper & Interventional & $\begin{array}{l}\text { To compare the effects } \\
\text { of aerobic exercise } \\
\text { training and yoga on } \\
\text { the functional capacity, } \\
\text { peripheral muscle } \\
\text { strength, quality of life } \\
\text { and fatigue in breast } \\
\text { cancer survivors. }\end{array}$ & $\begin{array}{l}\text { There were statistically significant increases in peripheral } \\
\text { muscle strength, the 6-Minute Walk Test distance and the } \\
\text { perception of QOL in both groups. Additionally, the group } \\
\text { with aerobic exercise and yoga showed marked improvement } \\
\text { compared with the aerobic exercise group in fatigue } \\
\text { perception. }\end{array}$ \\
\hline $\begin{array}{l}\text { Gültekin et al } \\
{[27]}\end{array}$ & Turkish & Journal paper & Review & $\begin{array}{l}\text { This review article } \\
\text { explores the status of } \\
\text { PC in the year } 2010 \text { in } \\
\text { Turkey. }\end{array}$ & $\begin{array}{l}\text { There were nine PC services across the country and seven } \\
\text { were located in university hospitals. There were } 72 \text { pain } \\
\text { centres of these, } 35 \text { were in located governmental hospitals } \\
\text { and } 31 \text { were in university hospitals while } 6 \text { were in the } \\
\text { private sector. Approximately } 40 \% \text { of pain centres were } \\
\text { located in Ankara and Istanbul. It was found that morphine } \\
\text { consumption rates per capita were relatively lower and the } \\
\text { availability of different types of opioid analgesics was limited. }\end{array}$ \\
\hline $\begin{array}{l}\text { Saygili and } \\
\text { Celik et al } \\
{[212]}\end{array}$ & Turkish & Journal paper & Case-control & $\begin{array}{l}\text { To evaluate the effect } \\
\text { of PC on the symptom } \\
\text { level assessment and } \\
\text { satisfaction of patients } \\
\text { diagnosed with cancer. }\end{array}$ & $\begin{array}{l}\text { The PC provided to } 60 \text { cancer patients at the PC centre was } \\
\text { less effective in reducing symptom levels (fatigue, nausea } \\
\text { and dyspnoea) compared with the } 59 \text { cancer patients who } \\
\text { received general care services at a public hospital. However, } \\
\text { the mean satisfaction of the patients who received services } \\
\text { at the PCC was significantly higher. }\end{array}$ \\
\hline $\begin{array}{l}\text { Ozcelik et al } \\
\text { [191] }\end{array}$ & Turkish & Journal paper & Review & $\begin{array}{l}\text { This review discussed } \\
\text { case management-based } \\
\text { multidiscıplinary care } \\
\text { protocol in the PC of } \\
\text { cancer patients. }\end{array}$ & $\begin{array}{l}\text { Care coordination and case management are essential of } \\
\text { a multidisciplinary team approach to provide effective and } \\
\text { quality care, to patients and families. A lot of care guidelines } \\
\text { and protocols are developed by a team of experts to } \\
\text { contribute to the PC activities and could be used. }\end{array}$ \\
\hline $\begin{array}{l}\text { Şenel et al } \\
\text { [123] }\end{array}$ & Turkish & Journal paper & Cross-sectional & $\begin{array}{l}\text { The objective of the } \\
\text { study was to describe } \\
\text { patterns of opioid use in } \\
\text { the PC clinic of a training } \\
\text { hospital. }\end{array}$ & $\begin{array}{l}\text { Out of } 418 \text { cancer patients, } 65 \% \text { were prescribed strong } \\
\text { opioids, } 26 \% \text { of patients were with weak opioids. The daily } \\
\text { oral morphine equivalent dose per patient was } 172 \pm 58 \mathrm{mg} \text {. } \\
\text { The indications for opioid use were pain (61\%), dyspnoea } \\
(19 \%) \text { and both dyspnoea and pain }(20 \%) .\end{array}$ \\
\hline Tekin [285] & Turkish & Journal paper & Case report & $\begin{array}{l}\text { This is a case report of an } \\
\text { old lady who had given } \\
\text { institutional care at the } \\
\text { terminal period of her } \\
\text { lung cancer. }\end{array}$ & $\begin{array}{l}\text { In this report, the interdisciplinary geriatric teamwork } \\
\text { including the role of the family physician was evaluated. }\end{array}$ \\
\hline
\end{tabular}


Supplementary Table 1. Details of the included studies. (Continued).

\begin{tabular}{|c|c|c|c|c|c|}
\hline $\begin{array}{l}\text { Uysal et al } \\
\text { [117] }\end{array}$ & Turkish & Journal paper & Interventional & $\begin{array}{l}\text { To evaluate the effect of } \\
\text { PC on patient symptoms } \\
\text { by recording changes } \\
\text { during the first week after } \\
\text { hospital admission. }\end{array}$ & $\begin{array}{l}\text { Among } 108 \text { patients admitted to the PC unit, } 50 \% \text { rated pain } \\
\text { intensity at the level of } 5 \text { upon admission, and in follow-up, } \\
\text { only } 6.5 \% \text { of patients had pain intensity at } 5 \text { on the } 7 \text { th day } \\
\text { of admission. The mean values of the symptoms of pain, } \\
\text { insomnia, loss of appetite and status of well-being decreased } \\
\text { significantly on the third day of admission compared to the } \\
\text { time of admission to the hospital. However, no significant } \\
\text { difference was found among the symptoms of nausea, } \\
\text { anxiety, shortness of breath and constipation after } 7 \text { days of } \\
\text { admission. }\end{array}$ \\
\hline Yildirim [286] & Turkish & Journal paper & Review & $\begin{array}{l}\text { To provide information } \\
\text { about complementary } \\
\text { therapies used by PC } \\
\text { cancer patients. }\end{array}$ & $\begin{array}{l}\text { Complementary medicine has become an important aspect } \\
\text { of palliative cancer care. Acupuncture, aromatherapy, } \\
\text { homeopathy, hypnotherapy, massage, reflexology, relaxation } \\
\text { techniques and spiritual healing are frequently used forms of } \\
\text { treatment. }\end{array}$ \\
\hline Çavdar [287] & Turkish & Journal paper & Review & $\begin{array}{l}\text { This article focuses } \\
\text { on the physiological, } \\
\text { psychological, spiritual } \\
\text { and sexual needs of } \\
\text { patients in the terminal } \\
\text { period. }\end{array}$ & $\begin{array}{l}\text { The needs and rights of dying patients and their } \\
\text { family members we discussed. The supporting approaches by } \\
\text { healthcare staff might reduce the burden to caregivers and } \\
\text { improve quality of life in the last hours. }\end{array}$ \\
\hline Kabalak [288] & Turkish & Journal paper & Review & $\begin{array}{l}\text { This paper status of PC in } \\
\text { Turkey in the year } 2014 \text {. }\end{array}$ & $\begin{array}{l}\text { Need for renewing existing PC programmes within } \\
\text { the framework of the country's current demographic, } \\
\text { economic, socio-cultural profile. The system should be } \\
\text { renewed according to its belief structure. A multidisciplinary } \\
\text { and multifaceted approach is needed for the improvements. }\end{array}$ \\
\hline $\begin{array}{l}\text { Ay and } \\
\text { Gençtürk [69] }\end{array}$ & Turkish & Journal paper & $\begin{array}{l}\text { Qualitative/ } \\
\text { focus group } \\
\text { discussion }\end{array}$ & $\begin{array}{l}\text { Midwifery student's } \\
\text { opinions related to death, } \\
\text { terminal period and } \\
\text { palliative } \\
\text { care. }\end{array}$ & $\begin{array}{l}\text { Midwifery students feel helplessness and inadequacy in } \\
\text { training to face terminal phase emotional support to the } \\
\text { dying patients and their caregivers. Adding PC education to } \\
\text { the midwifery curriculum is necessary to improve the quality } \\
\text { of care at the end of life. }\end{array}$ \\
\hline Demir [289] & Turkish & Journal paper & Review & $\begin{array}{l}\text { This article was aimed to } \\
\text { draw attention to ethical } \\
\text { dilemmas that arise with a } \\
\text { PC need. }\end{array}$ & $\begin{array}{l}\text { The paucity of trained and experienced PC healthcare } \\
\text { professionals in Turkey. PC ethical issues are necessary for } \\
\text { the training of healthcare providers. }\end{array}$ \\
\hline Isikhan [290] & Turkish & Journal paper & Review & $\begin{array}{l}\text { In this review, the choices } \\
\text { of the place of death of } \\
\text { cancer patients and the } \\
\text { factors that affect these } \\
\text { choices are discussed. }\end{array}$ & $\begin{array}{l}\text { For cancer patients and their caregivers in reaching the } \\
\text { period of dying in peace and dignity, the choice of place of } \\
\text { death is important in developing the quality of life during } \\
\text { dying. Hospice and home care are needed to developed and } \\
\text { PC team members and caregivers are needed to be trained. }\end{array}$ \\
\hline $\begin{array}{l}\text { Zengin and } \\
\text { Büyükbayram } \\
\text { [235] }\end{array}$ & Turkish & Journal paper & Cross-sectional & $\begin{array}{l}\text { Satisfaction levels of the } \\
\text { cancer patients in the PC } \\
\text { unit in terms of nursing } \\
\text { care. }\end{array}$ & $\begin{array}{l}\text { The satisfaction of the patients in terms of nursing was found } \\
\text { to be above average. It can be suggested to evaluate the } \\
\text { patient satisfaction in with nursing care and take steps to } \\
\text { increase satisfaction. }\end{array}$ \\
\hline
\end{tabular}


Supplementary Table 1. Details of the included studies. (Continued).

\begin{tabular}{|c|c|c|c|c|c|}
\hline Saruç [63] & Turkish & Journal paper & Review & $\begin{array}{l}\text { Role of social workers } \\
\text { in PC. }\end{array}$ & $\begin{array}{l}\text { In this study, the roles of the social worker in PC and } \\
\text { the professional standards established by the National } \\
\text { Association of Social Workers for social workers in palliative } \\
\text { and life care were discussed. }\end{array}$ \\
\hline $\begin{array}{l}\text { Koç et al } \\
{[239]}\end{array}$ & Turkish & Journal paper & Cross-sectional & $\begin{array}{l}\text { Factors effecting the } \\
\text { caregiving load of } \\
\text { caregivers for patients } \\
\text { with cancer. }\end{array}$ & $\begin{array}{l}71.2 \% \text { of patients with breast cancer have fatigue and } 48.2 \% \\
\text { have nausea. The care taking load scale of care takers was } \\
\text { average } 55.6 \pm 13.0,48.8 \% \text { of them have medium care load } \\
\text { and } 38.8 \% \text { of them have heavy care load. }\end{array}$ \\
\hline $\begin{array}{l}\text { Kurt et al } \\
\text { [242] }\end{array}$ & Turkish & Journal paper & Cross-sectional & $\begin{array}{l}\text { Quality of life of } \\
\text { caregivers of patients with } \\
\text { cancer and the affecting } \\
\text { factors. }\end{array}$ & $\begin{array}{l}\text { Most }(70.9 \%) \text { of the caregivers were female, and } 55.5 \% \\
\text { expressed that there was no one else for caring the patient, } \\
92.8 \% \text { of the caregivers were family member or relative of } \\
\text { the patient. The mean Caregiver Quality of Life Index-Cancer } \\
\text { total score of the caregivers was } 72.16 \pm 14.07 . \text { The quality } \\
\text { of life of the caregivers who had no another caregiver, no } \\
\text { social insurance and poor income status was found to be } \\
\text { statistically lower ( } p<0.05) \text {. }\end{array}$ \\
\hline $\begin{array}{l}\text { Akyar et al } \\
\text { [243] }\end{array}$ & Turkish & Journal paper & Cross-sectional & $\begin{array}{l}\text { Outcomes and changes in } \\
\text { their life due to caregiving } \\
\text { for elderly patients with } \\
\text { cancer. }\end{array}$ & $\begin{array}{l}\text { Caregivers reported negative impact in 'physical health, } \\
\text { coping strategies, relationship with friends, energy level, } \\
\text { emotional wellness, time for social activities and physical } \\
\text { functioning' and positive impact in 'relationship with the } \\
\text { patient'. }\end{array}$ \\
\hline $\begin{array}{l}\text { Bilgin et al } \\
\text { [182] }\end{array}$ & Turkish & Journal paper & Cross-sectional & $\begin{array}{l}\text { Levels of care } \\
\text { dependence and the } \\
\text { factors affecting care } \\
\text { dependence of inpatients } \\
\text { in nephrology and } \\
\text { oncology clinics. }\end{array}$ & $\begin{array}{l}\text { It was found that } 60.5 \% \text { of the oncology patients were care- } \\
\text { dependent. Education level }(p=0.006) \text {, economic status ( } p \\
<0.001) \text {, cane use }(p<0.001) \text {, hearing problem }(p<0.001) \text {, } \\
\text { speech problem }(p<0.001) \text {, chewing problem }(p<0.001) \\
\text { and walking problem }(p<0.001) \text { affected care dependency } \\
\text { significantly. }\end{array}$ \\
\hline Avcı [222] & Turkish & Journal paper & Cross-sectional & $\begin{array}{l}\text { Relationship between } \\
\text { the Nutrition Risk } \\
\text { Screening (NRS-2002 } \\
\text { scores) and haematologic } \\
\text { inflammation markers. }\end{array}$ & $\begin{array}{l}\text { The neutrophil/lymphocyte ratio (NLR), platelet/lymphocyte } \\
\text { ratio (PLR) are in correlation with NRS- } 2002 \text { scores. These } \\
\text { comparisons were made for the first time in the area of PC } \\
\text { centres. }\end{array}$ \\
\hline $\begin{array}{l}\text { Arslan et al } \\
{[170]}\end{array}$ & Turkish & Journal paper & $\begin{array}{l}\text { Cross-sectional } \\
\text { retrospective } \\
\text { file search } \\
\text { descriptive }\end{array}$ & $\begin{array}{l}\text { Effectiveness of palliative } \\
\text { pain management in } \\
\text { cancer patients. }\end{array}$ & $\begin{array}{l}\text { A significant reduction in pain scores with effective analgesic } \\
\text { treatment was observed. The mean VAS pain scores of } \\
\text { the patients recorded during hospitalisation was } 5.2 \pm 2.6 \\
\text { and the mean of these values at discharge was } 2.2 \pm 1.8 \text {. } \\
\text { Obstacles to the treatment of pain; the doctors who are } \\
\text { lack of information about pain treatment, fears about drug } \\
\text { addiction, the patients who hide their symptoms and ignoring } \\
\text { to symptom control as can be listed. }\end{array}$ \\
\hline
\end{tabular}


Supplementary Table 1. Details of the included studies. (Continued).

\begin{tabular}{|c|c|c|c|c|c|}
\hline Elçigil [55] & Turkish & Journal paper & Review & Nursing care for PC. & $\begin{array}{l}\text { An effective PC focuses on the patient and the family and } \\
\text { requires a multidisciplinary approach. Doctors, nurses, } \\
\text { social worker and religious functionaries play a role in PC. } \\
\text { A nurse involved in a PC team should be able to make a } \\
\text { comprehensive evaluation of patients and their families' } \\
\text { needs. She should have effective communication skills, } \\
\text { listen to them carefully, respect patients and their families' } \\
\text { knowledge and decisions. The nurse provides support and } \\
\text { care for all family members of a patient. The nurse in a special } \\
\text { PC team should be aware of their abilities and limitations. } \\
\text { She should always update their knowledge and skills. }\end{array}$ \\
\hline $\begin{array}{l}\text { Keser et al } \\
\text { [61] }\end{array}$ & Turkish & Journal paper & Review & $\begin{array}{l}\text { Physiotherapy and } \\
\text { rehabilitation for patients } \\
\text { with cancer. }\end{array}$ & $\begin{array}{l}277(54.5 \%) \text { patients received in-patient oncological } \\
\text { physiotherapy service while } 231 \text { ( } 45.5 \%) \text { received out-patient } \\
\text { oncological physiotherapy service. Five training programmes } \\
\text { were organised for the patients and their relatives. }\end{array}$ \\
\hline $\begin{array}{l}\text { Gelin and } \\
\text { Ulus [172] }\end{array}$ & Turkish & Journal paper & Cross-sectional & $\begin{array}{l}\text { Quality of life of the } \\
\text { patients receiving } \\
\text { chemotherapy and the } \\
\text { influencing factors. }\end{array}$ & $\begin{array}{l}\text { It has been observed that there is no difference between the } \\
\text { men and women in terms of their health condition, social life } \\
\text { and personal status. The scores of functional state of health } \\
\text { of men are higher than women while subscale scores of } \\
\text { emotional conditions of women are higher than men. There } \\
\text { is a positive correlation between the income and social life of } \\
\text { patients and their functional state of health. The functional } \\
\text { state of the health of the patients living with their family and } \\
\text { having no financial problems was higher compared to those } \\
\text { having financial problems. }\end{array}$ \\
\hline $\begin{array}{l}\text { Tunçel et al } \\
\text { [240] }\end{array}$ & Turkish & Journal paper & Cross-sectional & $\begin{array}{l}\text { Nurses' burnout in } \\
\text { oncology hospital care } \\
\text { unit. }\end{array}$ & $\begin{array}{l}\text { High levels of emotional exhaustion in } 82 \% \text { and } \\
\text { depersonalisation in } 51.4 \% \text { of nurses was determined. } \\
\text { Personal accomplishment was higher at } 80 \% \text {. Mild to } \\
\text { moderate emotional state and mild anxiety was revealed. } \\
\text { Years in profession, insufficient salary, finding the profession } \\
\text { suitable for herself, choosing the PC unit willingly, } \\
\text { satisfaction of work environment and social activity were } \\
\text { associated with burnout }(p \leq 0.05) \text {. }\end{array}$ \\
\hline $\begin{array}{l}\text { Karabulutlu } \\
\text { et al [245] }\end{array}$ & Turkish & Journal paper & Cross-sectional & $\begin{array}{l}\text { Sleep quality, anxiety and } \\
\text { depression levels and } \\
\text { affecting factors in cancer } \\
\text { caregivers. }\end{array}$ & $\begin{array}{l}\text { A statistically significant positive correlation was found } \\
\text { between sleep quality score and anxiety and depression } \\
\text { levels. } 88.7 \% \text { of caregivers had poor sleep quality and the } \\
\text { average total sleep quality was } 9.87 \pm 3.95 \text {. The rate of } \\
\text { anxiety was } 46 \% \text { and risk of depression was } 72 \% \text { among } \\
\text { caregivers. }\end{array}$ \\
\hline $\begin{array}{l}\text { Bağtatlı and } \\
\text { Eşer [78] }\end{array}$ & Turkish & Journal paper & Cross-sectional & $\begin{array}{l}\text { Pain assessments of } \\
\text { the nurses and factors } \\
\text { affecting their pain } \\
\text { assessments. }\end{array}$ & $\begin{array}{l}\text { The nurses working in oncology clinics mostly evaluate verbal } \\
\text { expressions of patients for assessing pain and none of them } \\
\text { used pain scale, the level of assessed pain was lower than } \\
\text { the self-report of cancer patients. Nurses' education level, } \\
\text { training about pain and working duration in oncology clinic } \\
\text { affected their pain assessment. }\end{array}$ \\
\hline
\end{tabular}


Supplementary Table 1. Details of the included studies. (Continued).

\begin{tabular}{|c|c|c|c|c|c|}
\hline $\begin{array}{l}\text { Yıldırım and } \\
\text { Gürkan [189] }\end{array}$ & Turkish & Journal paper & Cross-sectional & $\begin{array}{l}\text { The influence of music on } \\
\text { anxiety level of patients } \\
\text { and chemotherapy side } \\
\text { effects. }\end{array}$ & $\begin{array}{l}\text { The findings indicated that, music has a meaningful relation } \\
\text { with respect to anxiety states of the sample group ( } p> \\
0.05) \text {, and had no such a relation for the side effects of } \\
\text { chemotherapy }(p<0.001) \text {. }\end{array}$ \\
\hline $\begin{array}{l}\text { Kart et al } \\
{[199]}\end{array}$ & Turkish & Journal paper & Cross-sectional & $\begin{array}{l}\text { Medical cost of the } \\
\text { terminally ill cancer } \\
\text { patients hospitalised in } \\
\text { the medical intensive care } \\
\text { unit (ICU) of university } \\
\text { hospital. }\end{array}$ & $\begin{array}{l}\text { Medical cost of the } 15 \text { patients died in the intensive care unit } \\
\text { and two patients discharged with home mechanical ventilator } \\
\text { support was } 208.200,640 / T L \text {. They were hospitalised for } 233 \\
\text { bed/days. The number of beds occupied by these terminal } \\
\text { phase patients in this period was considered to be high. } \\
\text { Foundation of PC units or hospice service with necessary law } \\
\text { evaluations is very useful and important not only for optimal } \\
\text { use of limited financial sources but also for comfort of patient } \\
\text { and relatives. }\end{array}$ \\
\hline $\begin{array}{l}\text { Ateşçi et al } \\
\text { [224] }\end{array}$ & Turkish & Journal paper & Cross-sectional & $\begin{array}{l}\text { The prevalence of } \\
\text { psychiatric morbidity } \\
\text { among cancer patients } \\
\text { and the factors predicting } \\
\text { psychiatric morbidity. }\end{array}$ & $\begin{array}{l}28.7 \% \text { of cancer patients were found to have the diagnostic } \\
\text { and statistical manual (DSM-IV) Axis I diagnosis. The most } \\
\text { common diagnoses were adjustment disorder with depressed } \\
\text { mood (14\%) and major depressive disorder (11.3\%). Female } \\
\text { gender, awareness of the diagnosis of cancer, history of } \\
\text { previous premorbid psychiatric disorders and stress factors } \\
\text { were correlated with psychiatric morbidity }\end{array}$ \\
\hline $\begin{array}{l}\text { Usta } \\
\text { Yeşilbalkan } \\
\text { et al [173] }\end{array}$ & Turkish & Journal paper & Cross-sectional & $\begin{array}{l}\text { She symptoms due to } \\
\text { chemotherapy and their } \\
\text { effects on the quality of } \\
\text { life. }\end{array}$ & $\begin{array}{l}\text { During course of the treatment the patients feel 'a little' } \\
\text { anorexia ( } 39.8 \% \text { ) and 'a little' anger ( } 45.6 \%) \text {. A weak and } \\
\text { negative relationship was found between patients' overall } \\
\text { quality of life and physical ( } r=-0.2292) \text { and psychological ( } r \\
=-0.2379 \text { ) symptoms that they encountered throughout the } \\
\text { course of treatment. }\end{array}$ \\
\hline $\begin{array}{l}\text { Üzelli Yılmaz } \\
\text { et al [241] }\end{array}$ & Turkish & Journal paper & Cross-sectional & $\begin{array}{l}\text { Quality of nursing care in } \\
\text { a PC clinic. }\end{array}$ & $\begin{array}{l}\text { The average score of Care Behaviors- } 24 \text { Scale (BDI-24) was } \\
\text { found as } 5.59 \pm 0.15 \text { for nurses and } 5.10 \pm 0.15 \text { for patients. } \\
\text { There was no statistically significant difference between the } \\
\text { average of BDI- } 24 \text { total points and subscale scores of nurses } \\
\text { according to their gender, education status, working duration } \\
\text { in PC clinic and weekly. }\end{array}$ \\
\hline $\begin{array}{l}\text { Karabuğa } \\
\text { Yakar and } \\
\text { Pinar [216] }\end{array}$ & Turkish & Journal paper & Cross-sectional & $\begin{array}{l}\text { Quality of life and } \\
\text { effecting factors of } 120 \\
\text { caregivers of patients } \\
\text { with cancer. }\end{array}$ & $\begin{array}{l}\text { The quality of life of the caregivers assessed by Caregiver } \\
\text { Quality of Life Index-Cancer was quite low ( } 80.6 \pm 19.3) \text {. } \\
\text { They could not keep-up with daily life responsibilities } \\
\text { (53.3\%), and they had problems with their working life (30\%), } \\
\text { relationship within the family (15\%) and spouses (45\%). }\end{array}$ \\
\hline $\begin{array}{l}\text { Aydoğan and } \\
\text { Uygun [291] }\end{array}$ & Turkish & Journal paper & Review & $\begin{array}{l}\text { Palliative treatments in } \\
\text { cancer patients. }\end{array}$ & $\begin{array}{l}\text { PC should be part of comprehensive cancer care, rather than } \\
\text { a separate speciality. }\end{array}$ \\
\hline $\begin{array}{l}\text { Güngör } \\
\text { Tavşanlı et al } \\
\text { [65] }\end{array}$ & Turkish & Journal paper & Cross-sectional & $\begin{array}{l}\text { The feelings and attitudes } \\
\text { of nurses and nursing } \\
\text { students caring for } \\
\text { patients with cancer. }\end{array}$ & $\begin{array}{l}\text { Study group consisted students ( } 77.7 \% \text { ) whom } 75 \% \text { were } \\
\text { college freshman and } 52.9 \% \text { were graduates of non- } \\
\text { vocational high school, and nurses. The item 'I think it is } \\
\text { necessary for cancer patients to know about their illness' } \\
\text { was answered positively by } 91.1 \% \text { of fourth-year students. } \\
\text { The item 'I think it is necessary to tell patients the whole } \\
\text { truth concerning their treatment' was answered positively by } \\
67.9 \% \text { of fourth-year students }\end{array}$ \\
\hline
\end{tabular}


Supplementary Table 1. Details of the included studies. (Continued).

\begin{tabular}{|c|c|c|c|c|c|}
\hline $\begin{array}{l}\text { Sarıhan et al } \\
\text { [292] }\end{array}$ & Turkish & Journal paper & Review & $\begin{array}{l}\text { The importance of cancer } \\
\text { pain as a social problem } \\
\text { and pain management. }\end{array}$ & $\begin{array}{l}\text { Appropriate pain management with World Health } \\
\text { Organization analgesic ladder can improve patients' quality of } \\
\text { life and pain relief can be achieved in about } 80 \% \text { of patients. }\end{array}$ \\
\hline $\begin{array}{l}\text { İnci and Öz } \\
\text { [293] }\end{array}$ & Turkish & Journal paper & Review & PC and death anxiety. & $\begin{array}{l}\text { In terms of the end of life, it is expected that the nurse } \\
\text { stands by patient's family to help them in sustaining their } \\
\text { psychosocial wellness. In order to meet this expectation, } \\
\text { nurses should get a qualitative training for end of life care } \\
\text { along with good communication skills and coping strategies. }\end{array}$ \\
\hline $\begin{array}{l}\text { Uslu Sahan } \\
\text { and Terzioğlu } \\
\text { [294] }\end{array}$ & Turkish & Journal paper & Review & $\begin{array}{l}\text { PC education and } \\
\text { organisation in the World } \\
\text { and Turkey. }\end{array}$ & $\begin{array}{l}\text { In Turkey, the PC activities are supported with a number of } \\
\text { efforts for its integration with the national health system. } \\
\text { To overcome the problems experienced in the PC services, } \\
\text { the Cancer Control Department under the Ministry of } \\
\text { Health has designed a nurse based and community focused } \\
\text { project called 'PALLIA-TURK'. A considerable improvement } \\
\text { has been scored in the PC training and organisation within } \\
\text { the framework of this project, and such improvements are } \\
\text { expected to increase rapidly and steadily. }\end{array}$ \\
\hline $\begin{array}{l}\text { Avcl and } \mathrm{Avcl} \\
{[171]}\end{array}$ & Turkish & Journal paper & Review & $\begin{array}{l}\text { The effects of nutritional } \\
\text { status of the cancer } \\
\text { patients in the } \\
\text { PC unit (PCU) on } \\
\text { mortality and duration of } \\
\text { hospitalisation. }\end{array}$ & $\begin{array}{l}\text { There was a statistically significant difference between the } \\
\text { median hospitalisation days of patients admitted from home } \\
\text { and from hospital ( } 11 \text { days versus } 22 \text { days) ( } p=0.001 \text { ) in } \\
\text { PCU. Their median survival time for both groups were } 87.5 \\
\text { days and } 9 \text { days, respectively ( } p=0.017 \text { ). The death rates } \\
\text { were } 29.5 \% \text { for patients admitted from home and } 70.5 \% \text { for } \\
\text { patients admitted from other units of hospital ( } p=0.002 \text { ). } \\
\text { The NRS-2002 scores of the cancer patients who were } \\
\text { followed up at the palliative unit were correlated with the age } \\
\text { of the patients ( } r=0.365, p=0.003 \text { ) }\end{array}$ \\
\hline $\begin{array}{l}\text { Can et al } \\
{[124]}\end{array}$ & Turkish & Journal paper & Cross-sectional & $\begin{array}{l}\text { Pain palliation for lung } \\
\text { cancer patients. }\end{array}$ & $\begin{array}{l}\text { Of } 72 \text { lung cancer patients } 27.8 \% \text { had admitted with the only } \\
\text { complaint of pain. The median duration of hospital stay was } \\
7(2-45) \text { days. Among all the } 18 \% \text { of patients were not given } \\
\text { any analgesics; } 49 \% \text { had second line drug added and } 50 \% \\
\text { had received third line treatment. Hospitalisation indication } \\
\text { and discharge status of the patients were statistically } \\
\text { significant associated with analgesic use. }\end{array}$ \\
\hline $\begin{array}{l}\text { Benli and } \\
\text { Sunay [141] }\end{array}$ & Turkish & Journal paper & Cross-sectional & $\begin{array}{l}\text { Coordination of a PC unit } \\
\text { (PCU) and home health } \\
\text { care }(\mathrm{HHC}) \text { in a university } \\
\text { hospital and services of } \\
\text { PCU. }\end{array}$ & $\begin{array}{l}\text { During 2016, } 149 \text { patients were hospitalised in PCU. } \\
\text { Average hospitalisation duration was } 14 \pm 12(1-79) \text { days. } \\
\text { Neurological diseases and malignancies were the most } \\
\text { underlying diseases and nutritional support and decubitus } \\
\text { ulcers were the frequent etiologies for hospitalisation. Most } \\
\text { (78\%) of the patients were bedridden. Mortality rate was } 12 \% \\
\text { for } 1 \text { year. Performance scores of the patients at discharge } \\
\text { time were higher than scores at hospitalisation ( } p<0.001) \text {. }\end{array}$ \\
\hline
\end{tabular}


Supplementary Table 1. Details of the included studies. (Continued).

\begin{tabular}{|c|c|c|c|c|c|}
\hline $\begin{array}{l}\text { Babaoğlu and } \\
\text { Öz [223] }\end{array}$ & Turkish & Journal paper & Cross-sectional & $\begin{array}{l}\text { Psychological and social } \\
\text { problems of the spouses } \\
\text { of terminal cancer } \\
\text { patients. }\end{array}$ & $\begin{array}{l}\text { The most frequent psychological problem was depressive } \\
\text { affect and the most frequent social problem was impaired } \\
\text { social interactions. Physiological and social problems are } \\
\text { related with each other. Spiritual distress and hopelessness } \\
\text { were related with ineffective coping and ineffective role } \\
\text { performance, and ineffective coping was related with } \\
\text { impaired home maintenance and caregiver role strain. } \\
\text { The following significant relations are found for the social } \\
\text { problems. These relations are between; impaired home } \\
\text { maintenance, social interaction and role performance, } \\
\text { deficient diversional activity, social isolation. At the } \\
\text { same time it have been observed a relationship between } \\
\text { ineffective role performance and social isolation, too. }\end{array}$ \\
\hline $\begin{array}{l}\text { Gemalmaz } \\
\text { and Avşar } \\
{[257]}\end{array}$ & Turkish & Journal paper & Qualitative & $\begin{array}{l}\text { Feelings of patients after } \\
\text { the news of cancer and } \\
\text { changes of life. }\end{array}$ & $\begin{array}{l}\text { Patients easily shared their diagnosis of cancer with their } \\
\text { friends, but it was hard with family. They were overwhelmed } \\
\text { by intense concern of the family. The support of the family } \\
\text { in accepting the cancer after diagnosis was positive and they } \\
\text { also indicated they tend to feel spirituality more intensely. }\end{array}$ \\
\hline $\begin{array}{l}\text { Akgün and } \\
\text { Akan [54] }\end{array}$ & Turkish & Journal paper & Review & Paediatric PC. & $\begin{array}{l}\text { PC in children contains the assessment and handling of the } \\
\text { childrens' and family's physical, psychosocial and spiritual } \\
\text { needs and also symptom control and support to family during } \\
\text { the illness and mourning process. }\end{array}$ \\
\hline Okçin [56] & Turkish & Journal paper & Qualitative & $\begin{array}{l}\text { Professional life } \\
\text { experiences of nurses in } \\
\text { PC and oncology clinics. }\end{array}$ & $\begin{array}{l}\text { After the descriptive and interpretative analysis of the data, } \\
\text { three main themes and seven sub-themes were created. } \\
\text { Themes of challenges were fatigue, difficulty in coping/ } \\
\text { burnout and communication problems. Themes of gains were } \\
\text { professionalisation/satisfaction, meaning of life and death } \\
\text { and team harmony. Coping appeared as a sub-theme of field- } \\
\text { specific experience. }\end{array}$ \\
\hline $\begin{array}{l}\text { Kurşun et al } \\
\text { [125] }\end{array}$ & Turkish & Journal paper & Cross-sectional & $\begin{array}{l}\text { Characteristics of } 1,736 \\
\text { cancer patients and pain } \\
\text { management. }\end{array}$ & $\begin{array}{l}\text { The adjuvant pain medications were antidepressants, } \\
\text { corticosteroids, anticonvulsants, neuroleptics, } \\
\text { benzodiazepines, local anesthetics, bisphosphonates and } \\
\text { calcitonin and their rate of usage were } 61.0 \%, 7.1 \%, 4.0 \% \text {, } \\
4.0 \%, 1.6 \%, 12.3 \%, 1.2 \% \text { and } 2.8 \% \text {, respectively. }\end{array}$ \\
\hline $\begin{array}{l}\text { Orhan et al } \\
\text { [126] }\end{array}$ & Turkish & Journal paper & $\begin{array}{l}\text { Cross- } \\
\text { sectional }\end{array}$ & $\begin{array}{l}\text { Pain management } \\
\text { according to the World } \\
\text { Health Organization } \\
\text { analgesic ladder } \\
\text { treatment and other } \\
\text { treatment modalities in } \\
\text { cancer patients. }\end{array}$ & $\begin{array}{l}\text { WHO analgesic ladder was used for treatment algorithm in } \\
87.5 \% \text { of patients and invasive techniques were needed in } \\
12 \% \text { of patients. The number of successfully treated patients } \\
\text { in step I, II and III were } 11 \%, 73 \% \text { and } 14 \% \text {, respectively. } \\
\text { Also, } 43 \% \text { of patients used anticonvulsants or neuroleptics } \\
\text { and } 81 \% \text { of patients used antidepressants. Non-invasive } \\
\text { or invasive treatment modalities had to be added in } 7 \% \text { of } \\
\text { patients to augment the WHO analgesic ladder treatment. }\end{array}$ \\
\hline $\begin{array}{l}\text { Aygencel } \\
\text { and Türkoğlu } \\
\text { [208] }\end{array}$ & Turkish & Journal paper & Retrospective & $\begin{array}{l}\text { General characteristics } \\
\text { and } \\
\text { costs of terminal-stage } \\
\text { patients in a medical } \\
\text { intensive care unit (ICU). }\end{array}$ & $\begin{array}{l}\text { Eight percent of patients admitted to the ICU during the study } \\
\text { period were terminal-stage patients. The median age was } 63 \\
\text { years, } 52 \% \text { of patients were male and } 77 \% \text { of patients were } \\
\text { terminal-stage cancer patients. Despite full support therapy, } \\
\text { only } 4.8 \% \text { of the patients were discharged. The median cost } \\
\text { was } 2841 \mathrm{TL} \text {, and the total cost was } 581,353.2 \mathrm{TL} \text {. }\end{array}$ \\
\hline
\end{tabular}


Supplementary Table 1. Details of the included studies. (Continued).

\begin{tabular}{|c|c|c|c|c|c|}
\hline $\begin{array}{l}\text { Genç et al } \\
{[169]}\end{array}$ & Turkish & Journal paper & Cross-sectional & $\begin{array}{l}\text { Nonpharmacological } \\
\text { methods for the pain } \\
\text { management of cancer } \\
\text { patients. }\end{array}$ & $\begin{array}{l}\text { The average age of the patients participating in the study was } \\
58 \text {. Of the patients, } 53.7 \% \text { were female, } 53.7 \% \text { were literate- } \\
\text { primary school graduates and } 29.3 \% \text { had breast cancer. Of } \\
\text { the patients, } 54.4 \% \text { said they had severe pain, and } 82.9 \% \text { said } \\
\text { they used painkillers. It was found that } 87 \% \text { of the patients } \\
\text { prayed for the pain relief, } 63.4 \% \text { massage the pain area, } \\
59.3 \% \text { read the Qur'an and } 58.5 \% \text { used breathing exercises. }\end{array}$ \\
\hline $\begin{array}{l}\text { Bal Yılmaz } \\
\text { et al [146] }\end{array}$ & Turkish & Journal paper & Cross-sectional & $\begin{array}{l}\text { Parental knowledge of } \\
\text { cancer-related symptoms } \\
\text { and their attitude } \\
\text { regarding fatigue in } \\
\text { children treated for } \\
\text { cancer. }\end{array}$ & $\begin{array}{l}\text { Parents observed severe alopecia in } 48.3 \% \text {, fatigue in } 49.4 \% \text {, } \\
\text { nausea-vomiting in } 34.8 \% \text {, anxiety in } 24.7 \% \text {, moderate taste } \\
\text { change in } 23.6 \% \text {; constipation/diarrhoea in } 28.1 \% \text {, pain in } \\
7 \% \text {, sleeping difficulty in } 12.4 \% \text { and rare respiratory distress } \\
\text { in } 7.9 \% \text {. Parents reported cancer-related fatigue severely } \\
\text { affecting their children's school activity in } 43.8 \% \text {, friendships } \\
\text { in } 39.3 \% \text {, psychology in } 37.1 \% \text {, play activity in } 36 \% \text {, energy in } \\
29.2 \% \text { and family relationships in } 28.1 \% \text {. }\end{array}$ \\
\hline $\begin{array}{l}\text { Peker et al } \\
\text { [77] }\end{array}$ & Turkish & Journal paper & $\begin{array}{l}\text { Cross- } \\
\text { sectional }\end{array}$ & $\begin{array}{l}\text { Opinions, knowledge and } \\
\text { attitudes of doctors on } \\
\text { cancer pain management } \\
\text { in a university hospital. }\end{array}$ & $\begin{array}{l}\text { Two thirds of the doctors feel themselves 'insufficient' in } \\
\text { cancer pain management. Insufficiency feeling was more } \\
\text { prominent in tasks requiring knowledge, skill, education and } \\
\text { experience about opioid use. Most of the doctors believe } \\
\text { that barriers originating from health professionals and } \\
\text { systems are more important than the ones resulting from } \\
\text { patients and it was necessary to give high priority to pain } \\
\text { management than treatment of cancer; but still half of them } \\
\text { report that legal regulations have some influence on opioid } \\
\text { prescription; and almost three quarters of them believe that } \\
\text { opioid use may cause high rates of psychological addiction or } \\
\text { abuse. }\end{array}$ \\
\hline $\begin{array}{l}\text { Bilen et al } \\
\text { [127] }\end{array}$ & Turkish & Journal paper & Interventional & $\begin{array}{l}\text { The frequency of break- } \\
\text { through pain (BP) and } \\
\text { the efficiency of oral } \\
\text { transmucosal fentanyl } \\
\text { citrate (OTFC) for the } \\
\text { treatment. }\end{array}$ & $\begin{array}{l}\text { The frequency of BP was found as } 63.7 \% \text { in our study. The } \\
\text { appropriate OTFC dose in the titration phase was } 200 \mu \mathrm{g} \\
\text { for } 10 \text { patients, } 400 \mu \mathrm{g} \text { for } 21 \text { patients and } 800 \mu \mathrm{g} \text { for } 17 \\
\text { patients. In four patients OTFC failed to control their BP } \\
\text { attacks. An appropriate dose of OTFC was found effective in } \\
81.1 \% \text { of BP attacks. A significant difference was determined } \\
\text { in VAS scores before and after OTFC use }(p<0.001) . \text { The } \\
\text { average duration effect of OTFC was determined as } 17.7 \\
\pm 8.28 \text { minutes. No serious side effect was reported in any } \\
\text { patient. }\end{array}$ \\
\hline $\begin{array}{l}\text { Yilmaz and } \\
\text { Atay [66] }\end{array}$ & Turkish & Journal paper & Cross-sectional & $\begin{array}{l}\text { Pain management } \\
\text { knowledge of nursing } \\
\text { students. }\end{array}$ & $\begin{array}{l}\text { Nursing students took notice of pain complaint of their } \\
\text { patients ( } 86 \text { ) and they observed pain in the patients in } \\
\text { postoperative period ( } 51 \% \text { ). Half of the students ( } 48 \%) \\
\text { defined pain as a discomforting condition. In the sample } \\
\text { case given, } 63.5 \% \text { of the students defined the nursing } \\
\text { interventions in order of assessing the pain with scale, using } \\
\text { non-pharmacological methods, and giving analgesic drugs. } \\
\text { And } 36 \% \text { of the students stated giving analgesics according } \\
\text { to pain scale was routine nursing interventions. }\end{array}$ \\
\hline
\end{tabular}


Supplementary Table 1. Details of the included studies. (Continued).

\begin{tabular}{|c|c|c|c|c|c|}
\hline Işık et al [138] & Turkish & Journal paper & Cross-sectional & $\begin{array}{l}\text { Profile of patients using } \\
\text { home care health services } \\
\text { and evaluation of the } \\
\text { provided service. }\end{array}$ & $\begin{array}{l}\text { 'Home Health Care Services' was first introduced in as a part } \\
\text { of Health Transformation Programme brought health care to } \\
\text { home. It was aimed to be provided regular and quality health } \\
\text { care to patients such as elderly, bedridden, disabled or cancer } \\
\text { patients, people who have chronic diseases like joint-muscle } \\
\text { diseases and need care post-operative by professional medical } \\
\text { team in their own home environment with this programme. } \\
\text { In this study, the aim was to evaluate if the system met the } \\
\text { needs of patients and search the quality of home health care } \\
\text { service in Kırıkkale. Patients stated they were satisfied from } \\
\text { behaviour of personnel like their kindness and smiling faces } \\
\text { (\%4,0) and their attitudes when dealing with problems (3.97\%) } \\
\text { and competency (3.87\%). But explanations of the personnel } \\
\text { were inadequate ( } 21.3 \%) \text {. Overall, home health care services } \\
\text { provided in Kırıkkale meet the needs of patients. }\end{array}$ \\
\hline $\begin{array}{l}\text { Çivi et al } \\
{[174]}\end{array}$ & Turkish & Journal paper & Cross-sectional & $\begin{array}{l}\text { Depression in caregivers } \\
\text { of the patients with } \\
\text { cancer and factors } \\
\text { affecting their quality of } \\
\text { life. }\end{array}$ & $\begin{array}{l}\text { According to the values of the inventory, } 65.5 \% \text { were normal, } \\
24.5 \% \text { mildly, } 7.3 \% \text { moderately and } 2.7 \% \text { severely depressed. } \\
\text { The gender, occupation, education and marital status of the } \\
\text { caregivers of the cancer patients did not affect the depression } \\
\text { status ( } p>0.05 \text { ). When we compared the quality of life scores } \\
\text { and depression status, there were significant differences in } \\
\text { psychological health ( } p=0.000 \text { ), perception of overall health } \\
\text { and the satisfaction from life }(p=0.002) \text {, general health and } \\
\text { the quality of life ( } p=0.008 \text { ), physical health ( } p=0.001 \text { ) and } \\
\text { environmental area ( } p=0.025 \text { ) while there was no statistically } \\
\text { significant difference in social relationships ( } p=0.089 \text { ) } \\
\text { between the cases with and without depression. }\end{array}$ \\
\hline $\begin{array}{l}\text { Kardaş } \\
\text { Özdemir et al } \\
{[244]}\end{array}$ & Turkish & Journal paper & Cross-sectional & $\begin{array}{l}\text { Burden care of mothers of } \\
\text { children with malignancy. }\end{array}$ & $\begin{array}{l}\text { Average Zarit Burden Care of Scale scores of mothers were } \\
21.29 \pm 12.00 \text {. Care burden was related with income }(p< \\
0.05) \text {. Health perceptions were statistically different before } \\
\text { cancer and during caregiving period ( } p<0.001 \text { ). But, Burden } \\
\text { Care of Scale scores of mothers was not very high. }\end{array}$ \\
\hline $\begin{array}{l}\text { Düzgün et al } \\
\text { [225] }\end{array}$ & Turkish & Journal paper & Qualitative & $\begin{array}{l}\text { Bereavement in } \\
\text { caregivers of patients } \\
\text { died in PC unit (PCU) } \\
\text { and internal medicine } \\
\text { intensive care unit (ICU). }\end{array}$ & $\begin{array}{l}\text { As the patients' quality of life increases with the service } \\
\text { provided at the PC unit, the hope of recovery increases in } \\
\text { caregivers. Most caregivers expect the death is more likely in } \\
\text { ICU, that's why we think hope level was higher in PCU. }\end{array}$ \\
\hline $\begin{array}{l}\text { Madenoğlu } \\
\text { [295] }\end{array}$ & Turkish & Journal paper & Review & $\begin{array}{l}\text { To review the health care } \\
\text { on PC in Turkey. }\end{array}$ & $\begin{array}{l}\text { It is important to prevent symptoms in PC. Both } \\
\text { pharmacologic and nonpharmacologic methods should be } \\
\text { used to provide a comfortable life for all patients. }\end{array}$ \\
\hline $\begin{array}{l}\text { Gültaş and } \\
\text { Yılmaz [119] }\end{array}$ & English & Journal Paper & Cross-sectional & $\begin{array}{l}\text { To determine challenges } \\
\text { experienced by and } \\
\text { quality of life of relatives } \\
\text { of cancer patients } \\
\text { requiring PC at home. }\end{array}$ & $\begin{array}{l}\text { About } 50 \% \text { of care givers were women, } 75 \% \text { had difficulty } \\
\text { fulfilling their responsibilities, } 53.3 \% \text { experienced problems } \\
\text { in maintaining family relationships, } 96.7 \% \text { did not utilise } \\
\text { home care services and } 43 \% \text { did not receive information } \\
\text { about home care. The caregivers also had trouble managing } \\
\text { pain, nausea/vomiting, defaecation and mobility ( } 35 \%) \text {. } \\
\text { Respondents' quality of life was generally low. }\end{array}$ \\
\hline
\end{tabular}


Supplementary Table 1. Details of the included studies. (Continued).

\begin{tabular}{|c|c|c|c|c|c|}
\hline $\begin{array}{l}\text { Yildiz et al } \\
\text { [271] }\end{array}$ & English & $\begin{array}{l}\text { Letter to the } \\
\text { editor }\end{array}$ & $\begin{array}{l}\text { Qualitative/ } \\
\text { expert panel }\end{array}$ & $\begin{array}{l}\text { Choosing Wisely }{ }^{\circledR} \text { health } \\
\text { initiative. }\end{array}$ & $\begin{array}{l}\text { Choosing Wisely }{ }^{\circledR} \text { health initiative was established by the } \\
\text { American Board of Internal Medicine Foundation to advance } \\
\text { a national dialogue on avoiding unnecessary medical tests, } \\
\text { treatments and procedures in } 2012 \text {. The Turkish Society } \\
\text { of Internal Medicine (TSIM) has been working with the } \\
\text { European Federation of Internal Medicine within the frame of } \\
\text { the Choosing Wisely Project since January 2017. 'Don't delay } \\
\text { palliative care" is one of the recommendations that scored } \\
\text { the highest points among the members of TSIM. }\end{array}$ \\
\hline $\begin{array}{l}\text { Benli and } \\
\text { Erbesler [49] }\end{array}$ & Turkish & $\begin{array}{l}\text { Letter to } \\
\text { editor }\end{array}$ & Review & $\begin{array}{l}\text { Differences on } \\
\text { comprehension and } \\
\text { practice in PC in Turkey. }\end{array}$ & $\begin{array}{l}\text { Working with PC services together with home care services } \\
\text { will increase the efficiency of the service. When it is needed } \\
\text { for physician consult for a patient in home care service, } \\
\text { referring the patient to the PC service might improve care. } \\
\text { Since family physicians have more comprehensive approach } \\
\text { to their patients' home care systems would benefit their } \\
\text { contribution. }\end{array}$ \\
\hline $\begin{array}{l}\text { Guven et al } \\
\text { [296] }\end{array}$ & English & $\begin{array}{l}\text { Conference } \\
\text { abstract }\end{array}$ & Cross-sectional & $\begin{array}{l}\text { First } 5 \text { month experience } \\
\text { of outpatient PC clinic at } \\
\text { University hospital. }\end{array}$ & $\begin{array}{l}\text { A total of } 174 \text { patients were seen. The chief complaints } \\
\text { were pain ( } 26 \%) \text {, nausea and vomiting (13\%) and } \\
\text { decreased feeding (9\%). The most frequent interventions } \\
\text { were intravenous hydration, analgesic and/or antiemetic } \\
\text { administration and prescription. Thirty-three patients were } \\
\text { referred for immediate hospitalisation. The overall mortality } \\
\text { within the first } 30 \text { days after the first OPC visit was } 17 \% \text {. }\end{array}$ \\
\hline $\begin{array}{l}\text { Alkan et al } \\
\text { [297] }\end{array}$ & English & $\begin{array}{l}\text { Conference } \\
\text { abstract }\end{array}$ & Cross-sectional & $\begin{array}{l}\text { To evaluate the impact } \\
\text { of the patient-physician } \\
\text { relationship (PPR) on } \\
\text { Fear of cancer recurrence } \\
\text { (FCR). }\end{array}$ & $\begin{array}{l}\text { There was a high level of FCR scores in } 51 \% \text { of } 1,580 \text { cancer } \\
\text { survivors who were under remission. There was a negative } \\
\text { correlation between PPR and FCR scores. In multivariate } \\
\text { analysis; young age, being female, history of non-routine } \\
\text { imaging and worse were associated with high levels of FCR. }\end{array}$ \\
\hline Topkaya [97] & English & $\begin{array}{l}\text { Conference } \\
\text { abstract }\end{array}$ & Cross-sectional & $\begin{array}{l}\text { To determine the } \\
\text { PC needs of cancer } \\
\text { patients and to examine } \\
\text { the knowledge and } \\
\text { expectations of the } \\
\text { patients and their families } \\
\text { about PC. }\end{array}$ & $\begin{array}{l}\text { Among } 110 \text { patients and } 110 \text { patient's families, } 76.4 \% \text { of } \\
\text { the patients and } 60 \% \text { of their families were not aware of } \\
\text { palliative/supportive care. Expectations of } 99.1 \% \text { patients } \\
\text { and } 97.3 \% \text { of their families were to learn the treatment and } \\
\text { care plan; } 97.3 \% \text { of the patients and } 80 \% \text { of the families } \\
\text { wanted to be included and supported in the decisions } \\
\text { making. } 77.3 \% \text { of the patients } / 85.5 \% \text { of the families wants } \\
\text { to be supported psychologically, whereas } 77.3 \% \text { of the } \\
\text { patients } / 50 \% \text { of the families needed religious support. }\end{array}$ \\
\hline $\begin{array}{l}\text { Eskigulek and } \\
\text { Kav [118] }\end{array}$ & English & $\begin{array}{l}\text { Conference } \\
\text { abstract }\end{array}$ & Tool validation & $\begin{array}{l}\text { To evaluate Turkish } \\
\text { validity and reliability } \\
\text { of The Patient Dignity } \\
\text { Inventory (PDI) among PC } \\
\text { patients. }\end{array}$ & $\begin{array}{l}\text { Turkish version of the PDI is a valid and reliable instrument } \\
\text { among PC patients Cronbach's coefficient alpha for the PDI } \\
\text { was } 0.94 \text { and test-retest reliability was } R=0.75 \text {. }\end{array}$ \\
\hline $\begin{array}{l}\text { Bagcivan et al } \\
\text { [153] }\end{array}$ & English & $\begin{array}{l}\text { Conference } \\
\text { abstract }\end{array}$ & Cross-sectional & $\begin{array}{l}\text { To examine temporal } \\
\text { trends in the symptom } \\
\text { experience of cancer } \\
\text { patients presenting to an } \\
\text { outpatient PC clinic. }\end{array}$ & $\begin{array}{l}\text { Two hundred and thirty-eight cancer patients presenting to a } \\
\text { PC outpatient. Patients' most common symptoms were pain, } \\
\text { fatigue, disturbed sleep and mild to severe depression. }\end{array}$ \\
\hline
\end{tabular}


Supplementary Table 1. Details of the included studies. (Continued).

\begin{tabular}{|c|c|c|c|c|c|}
\hline $\begin{array}{l}\text { Kütük et al } \\
\text { [198] }\end{array}$ & Turkish & $\begin{array}{l}\text { Conference } \\
\text { abstract }\end{array}$ & Retrospective & $\begin{array}{l}\text { Demographic and clinical } \\
\text { data of cancer patients } \\
\text { who received palliative } \\
\text { chemotherapy in the last } \\
6 \text { months of their life. }\end{array}$ & $\begin{array}{l}\text { About } 28 \% \text { of } 262 \text { patients had colorectal cancer, } 10 \% \text { breast } \\
\text { cancer, } 33.5 \% \text { of them were bronchial cancer and } 28.5 \% \text { of } \\
\text { them were other solid cancers. The mean age at death was } \\
47 \text {, the male/female ratio was } 145 / 117 . \text { Among all } 42 \% \text { of } \\
\text { the patients had received palliative chemotherapy in the last } \\
\text { month of life. }\end{array}$ \\
\hline Akyar [266] & English & $\begin{array}{l}\text { Oral } \\
\text { presentation }\end{array}$ & Review & $\begin{array}{l}\text { Palliative and supportive } \\
\text { care in Turkey: literature } \\
\text { review and the current } \\
\text { status of research. }\end{array}$ & $\begin{array}{l}\text { Bibliographic reviews of published PC literature in Turkey } \\
\text { were presented. }\end{array}$ \\
\hline $\begin{array}{l}\text { Taçyıldız et al } \\
\text { [128] }\end{array}$ & Turkish & $\begin{array}{l}\text { Oral } \\
\text { presentation }\end{array}$ & Cross-sectional & $\begin{array}{l}\text { PC support and pain } \\
\text { management in terminally } \\
\text { ill patients. }\end{array}$ & $\begin{array}{l}\text { Pain is an important problem that should not be ignored. } \\
\text { Other problems we encounter in end-stage cancer patients } \\
\text { are nausea-vomiting, nutritional problems, respiratory } \\
\text { distress, depression, and chemotherapy side effects. }\end{array}$ \\
\hline $\begin{array}{l}\text { Palalı et al } \\
\text { [175] }\end{array}$ & Turkish & $\begin{array}{l}\text { Oral } \\
\text { presentation }\end{array}$ & Cross-sectional & $\begin{array}{l}\text { The frequency of pain } \\
\text { in children: the effect of } \\
\text { pain management and } \\
\text { quality of life. }\end{array}$ & $\begin{array}{l}\text { Pain management requires a multidisciplinary team } \\
\text { approach. Oncology nurses should determine the need } \\
\text { for pharmacological or non-pharmacological interventions } \\
\text { after the patient is admitted. Pain assessment is required } \\
\text { at least every } 8 \text { hours and more frequently after the painful } \\
\text { interventions or treatment. }\end{array}$ \\
\hline $\begin{array}{l}\text { Savran et al } \\
{[176]}\end{array}$ & Turkish & $\begin{array}{l}\text { Oral } \\
\text { presentation }\end{array}$ & Cross-sectional & $\begin{array}{l}\text { The relationship between } \\
\text { the quality of life of } \\
\text { children with cancer and } \\
\text { their parents' health care } \\
\text { satisfaction. }\end{array}$ & $\begin{array}{l}\text { It was found that increasing the quality of life of the child } \\
\text { increased the health care satisfaction of mothers. To increase } \\
\text { the quality of life of the child, it is necessary to eliminate the } \\
\text { symptoms experienced and plan nursing interventions for } \\
\text { these symptoms control. }\end{array}$ \\
\hline $\begin{array}{l}\text { Çırpan } \\
\text { Kantarcıoğlu } \\
\text { et al [226] }\end{array}$ & Turkish & $\begin{array}{l}\text { Oral } \\
\text { presentation }\end{array}$ & Cross-sectional & $\begin{array}{l}\text { Disease perception } \\
\text { among adolescents } \\
\text { diagnosed with cancer. }\end{array}$ & $\begin{array}{l}\text { Adolescents' negative beliefs should be determined and } \\
\text { replaced with more positive cognitive content. It was } \\
\text { reported that distressing symptoms such as pain required to } \\
\text { be reduced as much as possible. Besides these, emotional } \\
\text { states such as depression and anxiety should be treated. }\end{array}$ \\
\hline $\begin{array}{l}\text { Özdemir and } \\
\text { Taşçı [185] }\end{array}$ & Turkish & $\begin{array}{l}\text { Oral } \\
\text { presentation }\end{array}$ & Interventional & $\begin{array}{l}\text { Acupressure in fatigue } \\
\text { of elderly people with } \\
\text { cancer. }\end{array}$ & $\begin{array}{l}\text { Acupressure can be recommended to elderly people with } \\
\text { cancer as an easily applicable and tolerable method without } \\
\text { serious side effects in reducing cancer-related fatigue. }\end{array}$ \\
\hline Şen et al [186] & Turkish & $\begin{array}{l}\text { Oral } \\
\text { presentation }\end{array}$ & Interventional & $\begin{array}{l}\text { Reflexology for pain, } \\
\text { anxiety and } \\
\text { Nausea. }\end{array}$ & $\begin{array}{l}\text { A positive effect on pain, nausea and anxiety score after the } \\
\text { application of reflexology was noted in approximately } 100 \% \\
\text { of patients. }\end{array}$ \\
\hline $\begin{array}{l}\text { Gültaş and } \\
\text { Yılmaz [298] }\end{array}$ & Turkish & $\begin{array}{l}\text { Oral } \\
\text { Presentation }\end{array}$ & Cross-sectional & $\begin{array}{l}\text { Difficulties and quality } \\
\text { of life experienced by } \\
\text { caregivers of patients } \\
\text { with cancer needing PC } \\
\text { at home. }\end{array}$ & $\begin{array}{l}\text { Full dependency rate was } 26.7 \% \text { in taking a bath and } 23.3 \% \\
\text { in dressing and toilet needs. Most of the patients (61.7\%) can } \\
\text { take a bath, } 63 \% \text { can dress, } 65 \% \text { can meet their toilet needs, } \\
71.7 \% \text { can walk and } 65 \% \text { need help for meals. The total } \\
\text { quality of life scale score was } 49.7 \pm 12.7 \text { (min-max: } 34-94 \text { ) } \\
\text { and accordingly, their quality of life was low. }\end{array}$ \\
\hline Uğur et al [57] & Turkish & $\begin{array}{l}\text { Oral } \\
\text { presentation }\end{array}$ & Cross-sectional & $\begin{array}{l}\text { The perceptions of nurses } \\
\text { working in a university } \\
\text { hospital towards PC and } \\
\text { barriers of application. }\end{array}$ & $\begin{array}{l}\text { Not realising the patient's need for PC, lack of knowledge, } \\
\text { lack of communication with families and patients, inadequacy } \\
\text { of number of health professionals as well as PCUs and } \\
\text { barriers in health policies are among the important } \\
\text { deficiencies. }\end{array}$ \\
\hline
\end{tabular}


Supplementary Table 1. Details of the included studies. (Continued).

\begin{tabular}{|c|c|c|c|c|c|}
\hline $\begin{array}{l}\text { Kuşçu et al } \\
\text { [156] }\end{array}$ & Turkish & $\begin{array}{l}\text { Oral } \\
\text { presentation }\end{array}$ & Cross-sectional & $\begin{array}{l}\text { Hospitalisation indications } \\
\text { and nursing care need of } \\
\text { patients diagnosed with } \\
\text { malignancy. }\end{array}$ & $\begin{array}{l}\text { It has been observed that PC is very important in relieving } \\
\text { the physical and psycho-social symptoms of patients with a } \\
\text { curative treatment plan and nursing care need. }\end{array}$ \\
\hline Koku F [248] & Turkish & $\begin{array}{l}\text { Oral } \\
\text { presentation }\end{array}$ & Cross-sectional & $\begin{array}{l}\text { Nursing attitudes towards } \\
\text { patient care in the } \\
\text { terminal period. }\end{array}$ & $\begin{array}{l}\text { In-service training should be given frequently for nurses to } \\
\text { have knowledge and skills about the death symptoms and the } \\
\text { care of the dying patients. Communication skills, knowledge } \\
\text { of cultural differences and pain management are important } \\
\text { for those working at end-of-life care units. }\end{array}$ \\
\hline $\begin{array}{l}\text { Özçelik et al } \\
\text { [157] }\end{array}$ & Turkish & $\begin{array}{l}\text { Oral } \\
\text { presentation }\end{array}$ & Cross-sectional & $\begin{array}{l}\text { Symptom distribution of } \\
\text { advanced stage cancer } \\
\text { patients and factors } \\
\text { affecting them. }\end{array}$ & $\begin{array}{l}\text { The total symptom levels of the patients were high, they } \\
\text { experienced of pain and fatigue more intensely. Their } \\
\text { appetite and well-being levels were low. It was determined } \\
\text { that patients with low performance level experienced more } \\
\text { intense pain and lethargy symptoms. }\end{array}$ \\
\hline $\begin{array}{l}\text { Kutlutürkan } \\
\text { et al [177] }\end{array}$ & Turkish & $\begin{array}{l}\text { Oral } \\
\text { presentation }\end{array}$ & Cross-sectional & $\begin{array}{l}\text { The practices of cancer } \\
\text { patients regarding the } \\
\text { problems that develop } \\
\text { due to chemotherapy and } \\
\text { its effect on the quality } \\
\text { of life. }\end{array}$ & $\begin{array}{l}\text { RAND 36-Item Short Form Health Survey - } 32 \text { life scale } \\
\text { scores of cancer patients were below average. The patients } \\
\text { got the highest score from the physical function sub-scale } \\
\text { and the lowest score from the social function sub-scale. }\end{array}$ \\
\hline $\begin{array}{l}\text { Yavuzşen et al } \\
\text { [148] }\end{array}$ & Turkish & $\begin{array}{l}\text { Oral } \\
\text { presentation }\end{array}$ & Cross-sectional & $\begin{array}{l}\text { Symptom frequency } \\
\text { among patients receiving } \\
\text { outpatient chemotherapy. }\end{array}$ & $\begin{array}{l}\text { The most commonly reported symptom was fatigue. Fatigue } \\
\text { is a common symptom in advanced-stage patients, but is } \\
\text { usually undetectable if not questioned. }\end{array}$ \\
\hline $\begin{array}{l}\text { Karciga and } \\
\text { Oflaz [178] }\end{array}$ & Turkish & $\begin{array}{l}\text { Oral } \\
\text { presentation }\end{array}$ & Cross-sectional & $\begin{array}{l}\text { Quality of life (QoL) } \\
\text { and anxiety levels of } \\
\text { parents of children with } \\
\text { metastatic cancers. }\end{array}$ & $\begin{array}{l}\text { Cancer and its treatment ( } 53.1 \% \text { ) and the inability to go to } \\
\text { school ( } 23.8 \%) \text { were the most important problems affecting } \\
\text { daily life of children. There was no difference between the } \\
\text { age and education level of the parents and the child's age, } \\
\text { gender, disease duration, cancer type and metastatic organ } \\
\text { and QoL scores. However, QoL of housewives ( } 43.18 \pm \\
15.53 \text { ) and retired parents }(42.45 \pm 17.33 \text { ) were higher than } \\
\text { self-employed ( } 33.78 \pm 16.72) \text { workers ( } 38.75 \pm 16.82) \text { and } \\
\text { civil servants ( } 30.87 \pm 15.15) \text {. The chronic disease of the } \\
\text { parents negatively affects the total QoL and psychosocial } \\
\text { health score }(p<0.05) \text {. The QoL scores of children who can } \\
\text { go to school }(44.67 \pm 17.34) \text { were higher than those who } \\
\text { cannot go to school }(37.16 \pm 16.10) \text {, as well as those with } \\
\text { a good financial status }(44.24 \pm 20.75) \text { compared to other } \\
\text { groups ( } p<0.05) \text {. }\end{array}$ \\
\hline $\begin{array}{l}\text { Şener et al } \\
{[246]}\end{array}$ & Turkish & $\begin{array}{l}\text { Oral } \\
\text { presentation }\end{array}$ & Cross-sectional & $\begin{array}{l}\text { Care burden and life } \\
\text { satisfaction of caregivers } \\
\text { in the PC unit. }\end{array}$ & $\begin{array}{l}\text { There was no difference between the mean scores of Life } \\
\text { Satisfaction Scale and Care Burden Scale of the study and } \\
\text { control group patients' relatives. There was no correlation } \\
\text { between the mean scores of the Life Satisfaction Scale and } \\
\text { the Caregiving Burden Scale }(p>0.05) \text {. }\end{array}$ \\
\hline $\begin{array}{l}\text { Dokuyucu } \\
\text { et al [72] }\end{array}$ & Turkish & $\begin{array}{l}\text { Oral } \\
\text { presentation }\end{array}$ & Cross-sectional & $\begin{array}{l}\text { PC knowledge of the } \\
\text { healthcare professionals. }\end{array}$ & $\begin{array}{l}\text { It was found that the PC awareness levels of healthcare staff } \\
\text { were moderate and there were no major differences between } \\
\text { the doctors and nurses in terms of correct answers. }\end{array}$ \\
\hline
\end{tabular}


Supplementary Table 1. Details of the included studies. (Continued).

\begin{tabular}{|c|c|c|c|c|c|}
\hline $\begin{array}{l}\text { Dokuyucu } \\
\text { et al [236] }\end{array}$ & Turkish & $\begin{array}{l}\text { Oral } \\
\text { presentation }\end{array}$ & Cross-sectional & $\begin{array}{l}\text { Satisfaction of patients } \\
\text { from nursing service in PC } \\
\text { centre. }\end{array}$ & $\begin{array}{l}\text { Patients usually treated in PC centres have more depression. } \\
\text { Considering this, it was concluded that the care of the nurses } \\
\text { makes a high level of satisfaction. }\end{array}$ \\
\hline $\begin{array}{l}\text { Kırsever et al } \\
\text { [188] }\end{array}$ & Turkish & $\begin{array}{l}\text { Oral } \\
\text { presentation }\end{array}$ & Interventional & $\begin{array}{l}\text { Palliative bioresonance } \\
\text { therapy in metastatic } \\
\text { cancer patients. }\end{array}$ & $\begin{array}{l}\text { Significant symptomatic improvement and palliation were } \\
\text { observed with bioresonance in advanced stage cancer } \\
\text { patients. }\end{array}$ \\
\hline $\begin{array}{l}\text { Tapar et al } \\
\text { [150] }\end{array}$ & Turkish & $\begin{array}{l}\text { Oral } \\
\text { presentation }\end{array}$ & Cross-sectional & $\begin{array}{l}\text { Frequency of neuropathic } \\
\text { pain in patients with colon } \\
\text { cancer. }\end{array}$ & $\begin{array}{l}\text { The analgesics most frequently used were oxycodone } \\
2.7 \% \text {, antidepressant } 12.2 \% \text {, haloperidol } 21.6 \% \text {, morphine } \\
\text { tablet } 25.7 \% \text {, fentanyl transdermal } 31.1 \% \text {, tramadol tablet } \\
44.6 \% \text {, anticonvulsant (gabapentin, pregabalin) } 54.1 \% \text { and } \\
\text { Nonsteroidal anti-inflammatory + paracetamol } 60 \% \text {. The } \\
54.1 \% \text { of patients using anticonvulsant medication are using } \\
\text { an opioid medication together. }\end{array}$ \\
\hline $\begin{array}{l}\text { Erkal et al } \\
\text { [192] }\end{array}$ & Turkish & $\begin{array}{l}\text { Oral } \\
\text { presentation }\end{array}$ & Cross-sectional & $\begin{array}{l}\text { Evaluation of PC patients } \\
\text { treated in the tertiary } \\
\text { intensive care unit. }\end{array}$ & $\begin{array}{l}\text { It was found that } 21.4 \% \text { of intensive care patients were } \\
\text { cancer patients and need PC and the mortality was } 70 \% \text {. } \\
\text { The vast majority of patients requiring PC are treated in } \\
\text { intensive care units due to the lack of adequate beds in the } \\
\text { services. This increases the cost and eliminates the possibility } \\
\text { of treating patients who need intensive care but have the } \\
\text { chance to survive. }\end{array}$ \\
\hline $\begin{array}{l}\text { Bozkurt M } \\
\text { [299] }\end{array}$ & Turkish & $\begin{array}{l}\text { Oral } \\
\text { presentation }\end{array}$ & $\begin{array}{l}\text { Retrospective/ } \\
\text { cross-sectional }\end{array}$ & $\begin{array}{l}\text { Survival of advanced } \\
\text { gastric adenocarcinoma } \\
\text { patients referred to the } \\
\text { supportive care unit. }\end{array}$ & $\begin{array}{l}\text { It was found that } 50 \% \text { of patients with an expected life } \\
\text { expectancy of } \leq 3 \text { months lived for } 1.5 \text { months when referred } \\
\text { to supportive treatment. }\end{array}$ \\
\hline $\begin{array}{l}\text { Çakır and } \\
\text { Uzuner [300] }\end{array}$ & Turkish & $\begin{array}{l}\text { Oral } \\
\text { presentation }\end{array}$ & Cross-sectional & $\begin{array}{l}\text { The comfort of children } \\
\text { with cancer and their } \\
\text { parents with deep } \\
\text { sedation applied for } \\
\text { invasive procedures in } \\
\text { inpatient unit. }\end{array}$ & $\begin{array}{l}\text { Invasive procedures in children with cancer can be performed } \\
\text { safely with anaesthesiology guidance. Deep sedation in } \\
\text { inpatient unit both prevents the pain of the patients and } \\
\text { eliminates the concerns of the patients and parents. }\end{array}$ \\
\hline $\begin{array}{l}\text { Pilatin and } \\
\text { Araç [142] }\end{array}$ & Turkish & $\begin{array}{l}\text { Oral } \\
\text { presentation }\end{array}$ & Retrospective & $\begin{array}{l}\text { Retrospective analysis of } \\
\text { patients hospitalised in } \\
\text { the PC unit in Diyarbakır. }\end{array}$ & $\begin{array}{l}\text { The average age of the } 203 \text { patients was } 67 \text { (20-95) years. } \\
\text { It was found that } 54.5 \% \text { of the patients were hospitalised } \\
\text { due to malignancy and complications related to malignancy. } \\
\text { Average hospital stay was } 10.8 \text { days. About } 42 \% \text { of the } \\
\text { patients were discharged, } 13 \% \text { were expired and } 45 \% \text { were } \\
\text { referred to another centre. }\end{array}$ \\
\hline $\begin{array}{l}\text { Toprak and } \\
\text { Pilatin [143] }\end{array}$ & Turkish & $\begin{array}{l}\text { Oral } \\
\text { presentation }\end{array}$ & Retrospective & $\begin{array}{l}\text { Retrospective analysis of } \\
\text { patients hospitalised in } \\
\text { the } P C \text { unit. }\end{array}$ & $\begin{array}{l}\text { A total of } 137 \text { hospitalisations of } 98 \text { patients were detected. } \\
\text { The number of hospitalisations due to malignancy and } \\
\text { malignancy-related complications was } 108 \text { ( } 78.8 \%) \text {. Average } \\
\text { hospital stay was } 11.9 \text { days. Forty ( } 90.9 \% \text { ) of the patients } \\
\text { who died were hospitalised due to malignancy. }\end{array}$ \\
\hline
\end{tabular}


Supplementary Table 1. Details of the included studies. (Continued).

\begin{tabular}{|c|c|c|c|c|c|}
\hline $\begin{array}{l}\text { Akelma and } \\
\text { Platin [71] }\end{array}$ & Turkish & $\begin{array}{l}\text { Oral } \\
\text { presentation }\end{array}$ & Cross-sectional & $\begin{array}{l}\text { Views of healthcare } \\
\text { personnel working in a } \\
\text { Training and Research } \\
\text { Hospital regarding PC. }\end{array}$ & $\begin{array}{l}\text { A total of } 87 \text { healthcare personnel ( } 73 \text { nurses, } 3 \text { doctors, } 11 \\
\text { other) were included. } \\
64.4 \% \text { of the healthcare personnel stated that they did } \\
\text { not receive formal education about PC, } 54.8 \% \text { learned } \\
\text { PC in university, } 91.3 \% \text { stated that there was no training } \\
\text { programme about PC in their institution. They think that } \\
\text { patients who can benefit from PC the most were cancer } \\
\text { patients ( } 72.7 \% \text { ) and terminal period patients ( } 54.5 \% \text { ). } \\
\text { They think the purpose of PC is 'relieving the pain and } \\
\text { psychological relief of end-stage patients'. Almost all } \\
\text { individuals participating in the study stated that nurses, } \\
\text { doctors and psychologists should be included in the palliative } \\
\text { team and also pharmacists, volunteers and religious officials } \\
\text { might be included. } 76.5 \% \text { of them stated that PC can be } \\
\text { provided in hospital. The reason of why PC services have } \\
\text { not yet developed in our country was lack of knowledge } \\
\text { and training about palliative units according to } 91.2 \% \text { of } \\
\text { participants. The need for training programmes was basic } \\
\text { concepts of PC ( } 95.8 \% \text { ), communication and bereavement } \\
\text { (77.7\%). } 80.9 \% \text { of the healthcare personnel think that } \\
\text { 'Palliative care is for terminal stage cancer patients', } 85.7 \% \\
\text { think emotionally enhancing programmes should only cover } \\
\text { the caregivers. } 80.7 \% \text { of them stated that they agree/totally } \\
\text { agree with the statements 'the employee should control his/ } \\
\text { her emotions'. }\end{array}$ \\
\hline $\begin{array}{l}\text { Eren et al } \\
{[179]}\end{array}$ & Turkish & $\begin{array}{l}\text { Oral } \\
\text { presentation }\end{array}$ & Cross-sectional & $\begin{array}{l}\text { The effect of support } \\
\text { and evaluation of home } \\
\text { care on hospitalisation } \\
\text { frequency and quality of } \\
\text { care in cancer patients } \\
\text { requiring PC. }\end{array}$ & $\begin{array}{l}\text { It shows that the lack of knowledge and experience of } \\
\text { caregivers about terminal cancer patient care is an important } \\
\text { factor for frequency and desire of hospitalisation. The } \\
\text { terminal stage is an inevitable period in cancer. End of life } \\
\text { care loads more already busy oncology clinics. In the later } \\
\text { stages of our study, it was aimed to analyse the cost and } \\
\text { develop a hospitalisation scale that combines the factors } \\
\text { studied. }\end{array}$ \\
\hline $\begin{array}{l}\text { Topkaya et al } \\
\text { [161] }\end{array}$ & Turkish & $\begin{array}{l}\text { Oral } \\
\text { presentation }\end{array}$ & $\begin{array}{l}\text { Retrospective/ } \\
\text { cross-sectional }\end{array}$ & $\begin{array}{l}\text { Symptoms among } \\
\text { patients died with cancer. }\end{array}$ & $\begin{array}{l}\text { Study included } 45 \text { cancer patients who were followed up in } \\
\text { the oncology clinic and died. Palliative Performance Scale } \\
\text { of all were } 40 \% \text { and below. Seventy-six percent of patients } \\
\text { experienced more than one symptom and } 7 \% \text { had pain, } \\
\text { insomnia, respiratory distress and constipation together. } \\
\text { Other } 82 \% \text { had pain, } 41 \% \text { had pain \& insomnia, } 31 \% \text { had } \\
\text { constipation, } 57 \% \text { had respiratory distress, } 64 \% \text { patients } \\
\text { had respiratory distress, } 41 \% \text { of them experienced insomnia } \\
\text { and } 72 \% \text { of them experienced pain. } 29 \% \text { patients had } \\
\text { constipation and } 92 \% \text { of them had also pain. Planning the } \\
\text { appropriate treatment and care according to the complex } \\
\text { symptoms increases the success in symptom management } \\
\text { and increase the quality of life in end-of-life care. }\end{array}$ \\
\hline
\end{tabular}


Supplementary Table 1. Details of the included studies. (Continued).

\begin{tabular}{|c|c|c|c|c|c|}
\hline $\begin{array}{l}\text { Özyalçın and } \\
\text { Çevik [250] }\end{array}$ & Turkish & $\begin{array}{l}\text { Oral } \\
\text { presentation }\end{array}$ & Cross-sectional & $\begin{array}{l}\text { The attitudes of cancer } \\
\text { patients, their caregivers } \\
\text { and nurses towards death. }\end{array}$ & $\begin{array}{l}\text { The mean score of the well-being scale and the attitude } \\
\text { towards death scale (DAP-R) of the patients participating } \\
\text { in the study was higher than the relatives and nurses, and } \\
\text { the difference between them was found to be statistically } \\
\text { significant. A significant relationship was found between the } \\
\text { age, gender, marital status of the patients, and, the fear of } \\
\text { death, death avoidance and acceptance. }\end{array}$ \\
\hline $\begin{array}{l}\text { Topkaya and } \\
\text { Yürügen [214] }\end{array}$ & Turkish & $\begin{array}{l}\text { Oral } \\
\text { presentation }\end{array}$ & Cross-sectional & $\begin{array}{l}\text { PC needs of cancer } \\
\text { patients and to examine } \\
\text { the knowledge and } \\
\text { expectations of patients } \\
\text { and their families. }\end{array}$ & $\begin{array}{l}\text { The symptoms experienced by the patients according to } \\
\text { the Edmonton Symptom Scale were fatigue } 76.4 \% \text {, feeling } \\
\text { unwell } 73.6 \% \text {, loss of appetite } 66.4 \% \text {, pain } 64.5 \% \text {, worry } \\
62.7 \% \text {, insomnia } 56.4 \% \text { and nausea } 55.5 \% \text {. About } 76.4 \% \text { of } \\
\text { the patients and } 60 \% \text { of the families stated that they had } \\
\text { never heard of PC. While } 25 \% \text { of those who heard of PC } \\
\text { defined PC as end-of-life care, others defined it as symptom } \\
\text { management and supportive treatment with various } \\
\text { expressions. }\end{array}$ \\
\hline $\begin{array}{l}\text { Altınışık et al } \\
\text { [233] }\end{array}$ & Turkish & $\begin{array}{l}\text { Oral } \\
\text { presentation }\end{array}$ & Cross-sectional & $\begin{array}{l}\text { Supportive care needs } \\
\text { and hope levels of } \\
\text { caregivers of cancer } \\
\text { patients. }\end{array}$ & $\begin{array}{l}\text { There was no significant difference in the sociodemographic } \\
\text { characteristics of the patients and the unmet care needs of } \\
\text { the patients and their caregivers. } \\
\text { Significant differences were found in the stage of the } \\
\text { disease, the duration of diagnosis, the treatment status in } \\
\text { the last } 2 \text { months, the knowledge and the income level of } \\
\text { the caregiver. The most needed healthcare service was pain } \\
\text { control (39.3\%). The average score of the hope levels of the } \\
\text { caregivers is } 35.52 \pm 7.66 \text {. Regression analyses showed that } \\
\text { the advanced stage of the disease increased the needs of the } \\
\text { caregivers, and the treatment of the patient in the last two } \\
\text { months decreased the health care needs. }\end{array}$ \\
\hline $\begin{array}{l}\text { Özsoy et al } \\
\text { [151] }\end{array}$ & Turkish & $\begin{array}{l}\text { Oral } \\
\text { presentation }\end{array}$ & Cross-sectional & $\begin{array}{l}\text { Use of surgical procedures } \\
\text { among PC cancer } \\
\text { patients. }\end{array}$ & $\begin{array}{l}\text { A total of } 75 \text { patients underwent palliative surgery. The } \\
\text { most common symptoms were abdominal pain, vomiting and } \\
\text { weakness. Indications were; oral intake disorder, bleeding, } \\
\text { ileus, perforation, bile drainage deterioration (jaundice). } \\
\text { Stomach, colon and rectum were the most frequently } \\
\text { affected organs. }\end{array}$ \\
\hline $\begin{array}{l}\text { Kuşçu et al } \\
\text { [152] }\end{array}$ & Turkish & $\begin{array}{l}\text { Oral } \\
\text { presentation }\end{array}$ & Retrospective & $\begin{array}{l}\text { Retrospective analysis of } \\
\text { patients who underwent } \\
\text { acid palliative treatment } \\
\text { via catheter insertion. }\end{array}$ & $\begin{array}{l}\text { One hundred and seventy-nine oncology patients were } \\
\text { evaluated. Procedure reduces the number of repetitive } \\
\text { paracentesis, provides symptomatic relief, increases the } \\
\text { quality of life of the patient and his family. It also reduces the } \\
\text { number of clinical visits. No infection was seen except for } \\
\text { local infections due to catheter. }\end{array}$ \\
\hline
\end{tabular}


Supplementary Table 1. Details of the included studies. (Continued).

\begin{tabular}{|c|c|c|c|c|c|}
\hline $\begin{array}{l}\text { Kılıçkap et al } \\
\text { [162] }\end{array}$ & Turkish & $\begin{array}{l}\text { Oral } \\
\text { presentation }\end{array}$ & Cross-sectional & $\begin{array}{l}\text { The relationship } \\
\text { between quality of life } \\
\text { and clinicopathological } \\
\text { features in cancer } \\
\text { patients. }\end{array}$ & $\begin{array}{l}\text { The data of } 1,549 \text { cancer patients were analysed. The most } \\
\text { frequently observed diagnoses were breast cancer ( } 21 \%) \text {, } \\
\text { haematologic cancers (18\%) and colorectal cancer (11\%), } \\
\text { respectively. Individuals with ECOG performance status ' } 0 \text { ' } \\
\text { had higher quality of life scores (QLS) ( } p \leq 0.001 \text { ). As the } \\
\text { stage increased, the QoL decreased significantly ( } p \leq 0.001) \text {. } \\
\text { In patients with anaemia ( } 10 \mathrm{~g} / \mathrm{dL} \text { ), hypoalbuminaemia ( } 3.2 \\
\mathrm{~g} / \mathrm{dL} \text { ), and leukopenia ( } 3,000 / \mathrm{mm}^{3} \text { ), QoL was significantly } \\
\text { lower ( } p \leq 0.001) \text {. Inpatient treatment ( } p \leq 0.001) \text {, comorbid } \\
\text { disease ( } p \leq 0.001) \text {, family history of cancer ( } p \leq 0.001 \text { ), } \\
\text { active treatment ( } p \leq 0.001 \text { ), admitted within the first year } \\
\text { after diagnosis ( } p \leq 0.001 \text { ) and patients who had relapse } \\
\text { ( } p \leq 0.001 \text { ) had significantly lower QoL. Patients with } \\
\text { distant metastases had lower QoL compared to patients } \\
\text { with local metastases or non-metastases markedly ( } p \\
\leq 0.001 \text { ). According to the presence of the disease and } \\
\text { the status of receiving treatment, the general QoL of the } \\
\text { patients was found to be significantly different ( } p \leq 0.001) \text {. } \\
\text { Patients without active disease and who did not receive any } \\
\text { treatment, the overall QoL was the highest, while others } \\
\text { who had terminal disease and received active treatment had } \\
\text { the lowest ( } p \leq 0.001 \text { ). No relationship was found between } \\
\text { gender, marital status, previous cancer history and age and } \\
\text { overall quality of life score. }\end{array}$ \\
\hline $\begin{array}{l}\text { Aslan and } \\
\text { Akyol [228] }\end{array}$ & English & Poster & Cross-sectional & $\begin{array}{l}\text { Hope levels of } \\
\text { family caregivers of } \\
\text { cancer patients and } \\
\text { demographics. }\end{array}$ & $\begin{array}{l}\text { This research implied that family caregivers of cancer } \\
\text { patients had sufficient level of hope. Nevertheless, hope } \\
\text { levels of family caregivers can be reached to higher levels by } \\
\text { supportive care activities. }\end{array}$ \\
\hline $\begin{array}{l}\text { Bagcivan et al } \\
\text { [164] }\end{array}$ & English & Poster & Cross-sectional & $\begin{array}{l}\text { Evaluation of the } \\
\text { relationship between } \\
\text { level of nursing care } \\
\text { satisfaction } \\
\text { and symptom experience } \\
\text { due } \\
\text { to chemotherapy in } \\
\text { cancer patients. }\end{array}$ & $\begin{array}{l}\text { The total mean score of satisfaction scale was } 4.37 \pm 0.81 \\
\text { showing high patient satisfaction. It is a positive result for } \\
\text { nursing care. There were no significant difference between } \\
\text { patient socio-demographic variables and satisfaction mean } \\
\text { score. The most frequent symptoms of patients were lack of } \\
\text { appetite }(n=50,83.3 \%) \text {, debility ( } n=49,81.7 \%) \text { and nausea } \\
(n=41,68.3 \%) \text {. There were no relationship between patient } \\
\text { symptom severity and satisfaction mean score }(r=-0.094 \text {, } \\
p=0.474) \text {. }\end{array}$ \\
\hline $\begin{array}{l}\text { Özçelik et al } \\
\text { [247] }\end{array}$ & English & Poster & Cross-sectional & $\begin{array}{l}\text { The relationship between } \\
\text { caregiving burden } \\
\text { and social support in } \\
\text { caregivers of patients } \\
\text { with cancer. }\end{array}$ & $\begin{array}{l}\text { There were no significant differences between mean } \\
\text { caregiving burden, social support scores and some socio- } \\
\text { demographic characteristics (marital, employ, occupational } \\
\text { and to be primary caregiver status). The caregiving burden } \\
\text { levels of the caregivers were lower in patients with higher } \\
\text { educational background. There was a negative weak } \\
\text { significant correlation between the mean caregiving burden } \\
\text { scores and social support scores ( } r=-0.29, p=0.000 \text { ). The } \\
\text { results of the study show that caregiving burden of caregivers } \\
\text { can be reduced by increasing social support. }\end{array}$ \\
\hline
\end{tabular}


Supplementary Table 1. Details of the included studies. (Continued).

\begin{tabular}{|c|c|c|c|c|c|}
\hline $\begin{array}{l}\text { Okcin et al } \\
\text { [237] }\end{array}$ & English & Poster & Cross-sectional & $\begin{array}{l}\text { Nursing care satisfaction } \\
\text { of patients receiving } \\
\text { chemotherapy. }\end{array}$ & $\begin{array}{l}\text { Patients are influenced by nurses' personal behaviours } \\
\text { and outpatient chemotherapy patients want sufficient } \\
\text { information and emotional support. }\end{array}$ \\
\hline $\begin{array}{l}\text { Yetisen et al } \\
\text { [229] }\end{array}$ & English & Poster & Cross-sectional & $\begin{array}{l}\text { Scoring anxiety, } \\
\text { depression and quality of } \\
\text { life in colorectal cancer } \\
\text { patients and the effect of } \\
\text { patient education on } \\
\text { these parameters. }\end{array}$ & $\begin{array}{l}\text { There were not statistically significance changes in anxiety, } \\
\text { depression and the quality of life scores between groups. } \\
\text { Changes in the State-Trait-Anxiety-Inventory (STAI) scores } \\
\text { were statistically significant in study group after education. } \\
\text { The Short-Form-Health Survey (SF-36) measures eight } \\
\text { domains of health. We compared each domain and physical } \\
\text { functioning score was found statistically significant between } \\
\text { groups. }\end{array}$ \\
\hline $\begin{array}{l}\text { Yavas et al } \\
\text { [180] }\end{array}$ & English & Poster & Cross-sectional & $\begin{array}{l}\text { Quality of life in patients } \\
\text { with malign glioma: a } \\
\text { prospective study in } \\
\text { Turkish } \\
\text { Population. }\end{array}$ & $\begin{array}{l}\text { There were many changes about parameters related to both } \\
\text { quality of life and cognitive functions compared to baseline } \\
\text { scores and follow-up scores. Most of them were found to } \\
\text { be related to disease progression. We did not observe any } \\
\text { depression and anxiety in our patients. }\end{array}$ \\
\hline $\begin{array}{l}\text { Yavas et al } \\
\text { [301] }\end{array}$ & English & Poster & $\begin{array}{l}\text { Validation of } \\
\text { scale }\end{array}$ & $\begin{array}{l}\text { The assessment of Health } \\
\text { Related Quality of Life } \\
\text { (HRQOL) in adult patients } \\
\text { treated for low-grade } \\
\text { glioma. }\end{array}$ & $\begin{array}{l}\text { To assess quality of life, cognitive and emotional distress } \\
\text { on patients with diagnosis of high-grade glioma. European } \\
\text { Organization for Research and Treatment of Cancer Quality } \\
\text { of Life Questionnaire } 30 \text { (EORTC-C30), } \\
\text { Brain Cancer Module-20 (BN-20), Mini Mental Standard } \\
\text { Examination (MMSE) and Hospital Anxiety and Depression } \\
\text { Scale (HADS) were administered. } \\
\text { There were a statistically significant difference regarding to } \\
\text { cognitive function scores of the patients who used or did not } \\
\text { use antiepileptic drugs ( } p<0.001) \text {. We did not observe any } \\
\text { depression and anxiety in our patients. }\end{array}$ \\
\hline $\begin{array}{l}\text { Erol et al } \\
\text { [165] }\end{array}$ & English & Poster & Cross-sectional & $\begin{array}{l}\text { Pain experiences of } \\
\text { patients with cancer: a } \\
\text { phenomenological } \\
\text { Study. }\end{array}$ & $\begin{array}{l}\text { Patients with pain experienced fear and anxiety, restrictions } \\
\text { in daily life and constrained in pain management. The main } \\
\text { themes that emerged were pain perception, restrictions in } \\
\text { daily living, pain management and coping. The results of this } \\
\text { study can increase nurses' awareness of their role in pain } \\
\text { management. Patients need much more attention of health } \\
\text { professionals for pain control. }\end{array}$ \\
\hline $\begin{array}{l}\text { Koc et al } \\
{[166]}\end{array}$ & English & Poster & Cross-sectional & $\begin{array}{l}\text { Fatigue level and affecting } \\
\text { factors in oncologic } \\
\text { patients. }\end{array}$ & $\begin{array}{l}\text { Piper Fatigue Scale and Brief Fatigue Inventory were used. } \\
\text { The patients who were operated on with the diagnosis of } \\
\text { cancer suffered from moderate and intense fatigue levels, } \\
\text { while the patients in the control group experienced a mild } \\
\text { level of fatigue. }\end{array}$ \\
\hline $\begin{array}{l}\text { Yildiz et al } \\
\text { [187] }\end{array}$ & English & Poster & Interventional & $\begin{array}{l}\text { The effect of individual } \\
\text { physiotherapy and } \\
\text { rehabilitation training } \\
\text { programme on } \\
\text { lymphedema in patients } \\
\text { with mastectomy. }\end{array}$ & $\begin{array}{l}\text { Patient-specific home training programme may decrease the } \\
\text { amount of oedema and pain. The education given to patients } \\
\text { with breast cancer and candidates of lymphedema during the } \\
\text { early stage may increase the success of the treatment. }\end{array}$ \\
\hline
\end{tabular}


Supplementary Table 1. Details of the included studies. (Continued).

\begin{tabular}{|c|c|c|c|c|c|}
\hline $\begin{array}{l}\text { Çıracı and } \\
\text { Nural [230] }\end{array}$ & English & Poster & Cross-sectional & $\begin{array}{l}\text { Loneliness in cancer } \\
\text { patients. }\end{array}$ & $\begin{array}{l}\text { Oncology patients at end of their life felt high rates of } \\
\text { loneliness. }\end{array}$ \\
\hline $\begin{array}{l}\text { Tanriverdi } \\
\text { et al [302] }\end{array}$ & English & Poster & Cross-sectional & $\begin{array}{l}\text { The perspective of non- } \\
\text { oncologist physicians on } \\
\text { metastatic cancer patients } \\
\text { and PC } \\
\text { (ALONE study): Palliative } \\
\text { Care Working } \\
\text { Committee of the Turkish } \\
\text { Oncology Group. }\end{array}$ & $\begin{array}{l}\text { A total of } 71 \% \text { of participants identified all metastatic } \\
\text { patients as being terminal-stage, } 62 \% \text { were unaware of PC } \\
\text { techniques, } 64 \% \text { did not know about common supportive } \\
\text { care options, } 59 \% \text { were against hospice and } 63 \% \text { had no } \\
\text { opinion on resuscitation. }\end{array}$ \\
\hline $\begin{array}{l}\text { Çıracı and } \\
\text { Nural [231] }\end{array}$ & English & Poster & Cross-sectional & $\begin{array}{l}\text { Emotional status of } \\
\text { cancer patients } \\
\text { at end of life. }\end{array}$ & $\begin{array}{l}\text { Cancer patients not only feel physical symptoms but also feel } \\
\text { negative emotions such as loneliness, bargaining, not being } \\
\text { able to be with close friends at the end of life and they need } \\
\text { psychological support. }\end{array}$ \\
\hline Koc et al $\left[23^{2]}\right.$ & English & Poster & Cross-sectional & $\begin{array}{l}\text { Loneliness in oncologic } \\
\text { patients and social } \\
\text { support levels. }\end{array}$ & $\begin{array}{l}\text { The patients had lower perceived social support levels and } \\
\text { loneliness levels compared to the control group. }\end{array}$ \\
\hline $\begin{array}{l}\text { Sahin et al } \\
{[67]}\end{array}$ & English & Poster & Qualitative & $\begin{array}{l}\text { Thoughts of nursing } \\
\text { students about PC. }\end{array}$ & $\begin{array}{l}\text { Nursing students find their curriculum is superficial for PC } \\
\text { and would like it to be strengthened. They suggest that this } \\
\text { specialty content be expanded as part of a speciality degree } \\
\text { programme. }\end{array}$ \\
\hline $\begin{array}{l}\text { Cetintas et al } \\
\text { [68] }\end{array}$ & English & Poster & Cross-sectional & $\begin{array}{l}\text { Death anxiety and } \\
\text { attitudes toward the } \\
\text { principles of dying } \\
\text { with dignity of nursing } \\
\text { students. }\end{array}$ & $\begin{array}{l}\text { Death Anxiety Scale (DAS) and Assessment Scale of Attitudes } \\
\text { Toward Principles About Dying with Dignity scales were used. } \\
\text { There was a significant difference between the students } \\
\text { who witnessed the death of a child on 'uncertainty of death' } \\
\text { subscale mean scores of DAS ( } p<0.05 \text { ) and Assessment } \\
\text { Scale of Attitudes Toward Principles About Dying with } \\
\text { Dignity scores }(p<0.05) \text {. There was a negative correlation } \\
\text { between the number of deaths that students witnessed and } \\
\text { total scores of DAS ( } p=0.045) \text {. }\end{array}$ \\
\hline $\begin{array}{l}\text { Seven et al } \\
{[167]}\end{array}$ & English & Poster & Cross-sectional & $\begin{array}{l}\text { PC needs of patients with } \\
\text { cancer. }\end{array}$ & $\begin{array}{l}\text { The adapted Edmonton Symptom Assessment System, Beck } \\
\text { Depression Inventory (BDI) and Beck Anxiety Inventory (BAI) } \\
\text { were used to collect data. } \\
\text { Some symptoms are experienced by most of the patients } \\
\text { and some symptoms are felt by fewer patients, but more } \\
\text { severely. To reduce the negative effects of both physical } \\
\text { and psychological symptoms associated with cancer and } \\
\text { its treatment, nurses should evaluate these symptoms. The } \\
\text { implementation and assessment of the nursing attempts } \\
\text { should be tailored for each individual. }\end{array}$ \\
\hline Özkan [303] & English & poster & Review & $\begin{array}{l}\text { Self-care and end-of-life } \\
\text { care for cancer patients } \\
\text { and caregivers. }\end{array}$ & $\begin{array}{l}\text { There are important limitations of cancer self-care and PC } \\
\text { studies in assessing the cultural differences and failure to } \\
\text { cover all of the outcome measures. Researchers need to build } \\
\text { self-care and PC that paralleled advances in clinical research } \\
\text { and practice intended for cancer patients. }\end{array}$ \\
\hline
\end{tabular}


Supplementary Table 1. Details of the included studies. (Continued).

\begin{tabular}{|c|c|c|c|c|c|}
\hline $\begin{array}{l}\text { Koc et al } \\
{[181]}\end{array}$ & English & Poster & Qualitative & $\begin{array}{l}\text { Life quality, satisfaction } \\
\text { and pain perception } \\
\text { in cancer patients. }\end{array}$ & $\begin{array}{l}\text { Patients evaluate their life quality as a whole, that their } \\
\text { general wellness is very low, that they are partially not happy } \\
\text { with their life satisfaction and that they have more than } \\
\text { average pain perception. }\end{array}$ \\
\hline $\begin{array}{l}\text { Çolak et al } \\
\text { [129] }\end{array}$ & English & Poster & Cross-sectional & $\begin{array}{l}\text { The attitudes of cancer } \\
\text { patients about morphine } \\
\text { usage for pain } \\
\text { management. }\end{array}$ & $\begin{array}{l}\text { The age }(p=0.010) \text { and gender of the patient }(p=0.038) \\
\text { and their knowledge about morphine }(p=0.000) \text { had a } \\
\text { statistically significant effect on the preference of the } \\
\text { patients. The patients who defined morphine as narcotic } \\
\text { drug were less likely to use morphine }(p=0.015) \text {. There was } \\
\text { no relationship between the patients' preference and the } \\
\text { diagnosis }(p=0.247) \text {, the stage }(p=0.552) \text {, the education } \\
\text { status ( } p=0.112) \text { and the pain. The risk of addiction to } \\
\text { opioids remains a major obstacle preventing effective pain } \\
\text { management. }\end{array}$ \\
\hline $\begin{array}{l}\text { Cakir and } \\
\text { Kaygusuz } \\
{[304]}\end{array}$ & English & Poster & Cross-sectional & $\begin{array}{l}\text { Nasogastric tube feeding } \\
\text { in children with cancer as } \\
\text { a part of } \\
\text { PC. }\end{array}$ & $\begin{array}{l}\text { Weight loss is an important problem in patients with cancer. } \\
\text { Patients who lost weight should be fed by nasogastric } \\
\text { tube (NG). Palliative enteral feeding by NG tube is safe, } \\
\text { inexpensive, and has a low complication rate. NG feeding, } \\
\text { rather than PEG, could be better than enteral feeding in } \\
\text { children with cancer. }\end{array}$ \\
\hline $\begin{array}{l}\text { Bağçivan et al } \\
\text { [305] }\end{array}$ & English & Poster & $\begin{array}{l}\text { Validity and } \\
\text { reliability of } \\
\text { scale }\end{array}$ & $\begin{array}{l}\text { Analysis of the patient- } \\
\text { related barriers in cancer } \\
\text { pain management in } \\
\text { Turkish patients. }\end{array}$ & $\begin{array}{l}\text { Barriers Questionnaire-II (BQ-II) was a valid and reliable scale } \\
\text { for patient related barriers in cancer pain management. Items } \\
\text { suggested by patients such as 'family related barriers' and } \\
\text { 'family members' role and responsibilities' } \\
\text { could be added to the BQ-II for future studies. }\end{array}$ \\
\hline $\begin{array}{l}\text { Eskigülek and } \\
\operatorname{Kav}[234]\end{array}$ & English & Poster & $\begin{array}{l}\text { Validity and } \\
\text { reliability of } \\
\text { scale }\end{array}$ & $\begin{array}{l}\text { Turkish validity and } \\
\text { reliability of the Patient } \\
\text { Dignity Inventory (PDI) } \\
\text { among PC patients and to } \\
\text { explore the views of PC } \\
\text { patients and nurses about } \\
\text { dignified care. }\end{array}$ & $\begin{array}{l}\text { Cronbach's coefficient alpha for The Patient Dignity } \\
\text { Inventory (PDI) was } 0.94 \text { and test-retest reliability was } r \\
=0.75 \text {. Concurrent validity tests demonstrated positive } \\
\text { significant correlations between factors of PDI and Hospital } \\
\text { Anxiety and Depression Scale (HADS). Factor analysis } \\
\text { demonstrated five factors accounting for } 68.7 \% \text { of the overall } \\
\text { variance. The factors were labelled as symptom distress, } \\
\text { existential distress, self-confidence, dependency and, support } \\
\text { and care requirements. Three themes emerged through data } \\
\text { obtained from PC patients: respectability, caring practices } \\
\text { and usefulness. Three themes emerged through data } \\
\text { obtained from PC nurses: maintaining one's respectability, } \\
\text { barriers and recommendations and benefits of care. }\end{array}$ \\
\hline $\begin{array}{l}\text { Gok Metin } \\
\text { et al [168] }\end{array}$ & English & Poster & $\begin{array}{l}\text { Randomised } \\
\text { controlled trial }\end{array}$ & $\begin{array}{l}\text { The effect of mindfulness- } \\
\text { based stress reduction } \\
\text { (MBSR) and progressive } \\
\text { muscle relaxation (PMR) } \\
\text { for breast cancer patients } \\
\text { receiving adjuvant } \\
\text { paclitaxel regimen. }\end{array}$ & $\begin{array}{l}\text { Brief Fatigue Inventory (BFI) scores were significantly } \\
\text { decreased in the MBSR, PMR groups compared with the } \\
\text { control group. The sub-dimension scores of Brief COPE } \\
\text { including denial, behavioural disengagement, acceptance, } \\
\text { humour, using emotional support, using instrumental } \\
\text { support, substance use, planning and positive reframing were } \\
\text { significantly higher in the MBSR and PMR groups. Regarding } \\
\text { FLIC scores, there were no significant differences between } \\
\text { the groups. }\end{array}$ \\
\hline
\end{tabular}


Supplementary Table 1. Details of the included studies. (Continued).

\begin{tabular}{|c|c|c|c|c|c|}
\hline $\begin{array}{l}\text { Kılıçkap et al } \\
\text { [163] }\end{array}$ & Turkish & Poster & Cross-sectional & $\begin{array}{l}\text { Impact of the quality } \\
\text { of life at the time of } \\
\text { diagnosis on overall } \\
\text { survival of cancer } \\
\text { patients. }\end{array}$ & $\begin{array}{l}\text { Data of } 457 \text { patients were analysed. The most common } \\
\text { diagnoses were lung ( } 19 \% \text { ), haematologic (14\%) and } \\
\text { colorectal (10.5\%) cancer, respectively, and } 51 \% \text { had stage } \\
4 \text { disease. ECOG PS were zero in } 60 \% \text { of the patients. Sixty- } \\
\text { eight percent of the cases were on treatment: } 87 \% \text { were } \\
\text { receiving chemotherapy and } 29 \% \text { were treated inpatient. } \\
\text { Comorbid diseases were found in } 26 \text { percent of the cases. } \\
\text { Advanced stage, low haemoglobin and albumin level, } \\
\text { ECOG PS } \geq 1 \text {, hospitalisation, comorbid disease and distant } \\
\text { metastasis were associated with quality of life (QoL) score. } \\
\text { The median follow-up period was } 25 \text { months ( } 1-60 \text { ). Overall } \\
\text { survival was significantly lower in patients with a low QoL } \\
\text { score at the time of diagnosis (median } 10 \text { versus } 40 \text { months; } \\
p \leq 0.001 \text { ). The } 3 \text {-year OS was lower in individuals with low } \\
\text { QoL ( } 27 \% \text { versus } 52 \% \text { ). In multivariate analysis, stage ( } p \leq \\
0.001) \text {, hypoalbuminaemia ( } p \leq 0.001 \text { ), ECOG performance } \\
\text { score ( } p \leq 0.001 \text { ), and low QoL ( } p=0.022 \text { ) were independent } \\
\text { variables affecting survival. } \\
\text { Low quality of life score at diagnosis is an independent } \\
\text { variable affecting survival. Application of the QoL scale may } \\
\text { be useful in every newly diagnosed patient. }\end{array}$ \\
\hline $\begin{array}{l}\text { Sezer et al } \\
\text { [145] }\end{array}$ & Turkish & Poster & Retrospective & $\begin{array}{l}\text { Characteristics of patients } \\
\text { who received inpatient } \\
\text { treatment in PC centre } \\
\text { between } 2008 \text { and } 2009 .\end{array}$ & $\begin{array}{l}\text { During a year } 352 \text { patients were hospitalised in } 557 \text { times. } \\
\text { Their gender was } 55 \% \text { were male and } 45 \% \text { were female, } \\
\text { and the mean ages for both sexes were } 56.3 \text { and } 54.5 \text {. } \\
\text { Diagnoses were lung cancer ( } 27.8 \% \text { ), gastrointestinal system } \\
\text { cancer ( } 20.2 \%) \text {, haematological malignancy ( } 9.9 \%) \text {, breast } \\
\text { cancer ( } 10.8 \% \text { ), gynaecological cancer ( } 8.8 \%) \text {, head and neck } \\
\text { tumours ( } 7.6 \%) \text {, urogenital ( } 5.4 \%) \text {, malignant melanoma } \\
(2.4 \%) \text {, nervous system tumour ( } 2.8 \% \text {, soft tissue and bone } \\
\text { tumours ( } 4.6 \%) \text {. } \\
\text { Reasons for hospitalisation were: diagnosis and } \\
\text { chemotherapy ( } 35.7 \%) \text {, complications ( } 34.7 \% \text { ) and PC } \\
\text { (29.6\%). Average hospital stay was } 6 \text { days for diagnosis and } \\
\text { chemotherapy, } 9 \text { days for complications and } 18 \text { days for } \\
\text { PC. Major complications were infection and bone marrow } \\
\text { depression ( } 42 \%) \text {. Most of the patients hospitalised for } \\
\text { palliative purposes were for pain palliation and nutrition } \\
\text { support. Compared to the previous year, it was found that } \\
\text { the duration of hospitalisation for PC was prolonged, and } \\
\text { the duration of diagnosis and chemotherapy was shortened. } \\
\text { Our aim is to increase PC opportunities, to shorten the } \\
\text { complication rates and the duration of hospital stay by } \\
\text { making good follow-up after chemotherapy. }\end{array}$ \\
\hline
\end{tabular}


Supplementary Table 1. Details of the included studies. (Continued).

\begin{tabular}{|c|c|c|c|c|c|}
\hline $\begin{array}{l}\text { Kömürcü et al } \\
\text { [197] }\end{array}$ & Turkish & Poster & Cross-sectional & $\begin{array}{l}\text { Tests and treatments } \\
\text { performed during the last } \\
2 \text { weeks among terminal } \\
\text { stage cancer patients who } \\
\text { died. }\end{array}$ & $\begin{array}{l}\text { There were } 422 \text { metastatic cancer patients with a life } \\
\text { expectancy of } 6 \text { months. Causes of death in order of } \\
\text { frequency; respiratory failure ( } 48.1 \%) \text {, infection ( } 23.5 \% \text { ) and/ } \\
\text { or liver failure ( } 18.9 \%) \text {. The examinations performed during } \\
\text { last } 2 \text { weeks were; } 22.7 \% \text { computed tomography, } 23.2 \% \\
\text { ultrasonography, } 13.7 \% \text { magnetic resonance imaging and } \\
4.9 \% \text { bone scintigraphy. In all } 76.9 \% \text { of the patients received } \\
\text { intravenous serum treatment, } 43.6 \% \text { erythrocyte transfusion, } \\
36.5 \% \text { total parenteral nutrition and } 6.9 \% \text { albumin } \\
\text { transfusion. It was observed that } 25.7 \% \text { received invasive } \\
\text { pain treatment, } 12.4 \% \text { terminal sedation with morphine or } \\
\text { midazolam and } 9.1 \% \text { chemotherapy. In addition, vascular } \\
\text { access was established in all patients, a central catheter } \\
\text { and/or urinary catheter was inserted in } 37.9 \% \text {; It was found } \\
\text { that } 10 \% \text { had paracentesis, } 7.3 \% \text { thoracentesis and } 2.9 \% \\
\text { endoscopy. }\end{array}$ \\
\hline $\begin{array}{l}\text { Doruk et al } \\
\text { [201] }\end{array}$ & Turkish & Poster & Cross-sectional & $\begin{array}{l}\text { Pain management and } \\
\text { supportive treatments } \\
\text { in terminal cancer } \\
\text { patients in hospital. }\end{array}$ & $\begin{array}{l}\text { The average length of stay in the hospital was } 16.9(2-74) \\
\text { days. Chemotherapy (CT) was given in } 44 \% \text { of the patients } \\
\text { and } 45 \% \text { of them received CT within } 14 \text { days before death. } \\
\text { The average time from CT to death was } 59.9 \text { ( } 3-138) \text { days. } \\
\text { During their hospitalisation, invasive interventions ( } 42 \%) \text {, } \\
\text { parenteral nutrition ( } 16 \% \text { ), albumin infusion ( } 50 \% \text { ) and fresh } \\
\text { frozen plasma ( } 12 \% \text { ) were given. A significant relief was } \\
\text { noted for symptoms of pain, anorexia, nausea, vomiting, } \\
\text { constipation, shortness of breath and insomnia with the } \\
\text { supportive treatment ( } p=0.002-p=0.008 \text { ). }\end{array}$ \\
\hline $\begin{array}{l}\text { Tanrıverdi and } \\
\text { Yıldırım [306] }\end{array}$ & Turkish & Poster & $\begin{array}{l}\text { Retrospective/ } \\
\text { cross-sectional }\end{array}$ & $\begin{array}{l}\text { Evaluation of end-stage } \\
\text { cancer patients who } \\
\text { applied to the emergency } \\
\text { department } 1 \text { month } \\
\text { before their death. }\end{array}$ & $\begin{array}{l}\text { Study group consisted of } 107 \text { deceased cancer patients who } \\
\text { applied to the emergency service. In Group 1, there were } \\
64 \text { patients admitted to the emergency department at least } \\
\text { once in a month before their death. Remaining } 43 \text { had never } \\
\text { needed the emergency department within } 1 \text { month before } \\
\text { their death (Group } 2 \text { ). Thirty-eight percent of patients in } \\
\text { group } 1 \text { had lung cancer and the most common reason for } \\
\text { presentation was dyspnoea ( } 92 \% \text { ) and } 26 \% \text { of the patients } \\
\text { in group } 2 \text { had colorectal cancer. In Group } 1,38 \% \text { of the } \\
\text { patients were discharged from the emergency room and } 9 \% \\
\text { died in the emergency room. It was found that } 10 \% \text { of the } \\
\text { patients in group } 1 \text { were hospitalised in ICU, and the rest } \\
\text { were hospitalised in: oncology ( } 28 \% \text { ), chest or infectious } \\
\text { diseases (11\%) and general surgery (4\%) wards. Patients who } \\
\text { applied to the emergency department. In the last month of } \\
\text { their lives were positively correlated with tumour location } \\
\text { (primary lung or lung metastasis), good performance status, } \\
\text { presence of pleural effusion and the presence of pain. }\end{array}$ \\
\hline $\begin{array}{l}\text { Ekinci et al } \\
{[144]}\end{array}$ & Turkish & Poster & Cross-sectional & $\begin{array}{l}\text { Characteristics of patients } \\
\text { treated in a PC centre. }\end{array}$ & $\begin{array}{l}\text { Most patient had cancer. Among the reasons of admission, } \\
\text { the first was nutritional support. }\end{array}$ \\
\hline
\end{tabular}


Supplementary Table 1. Details of the included studies. (Continued).

\begin{tabular}{|c|c|c|c|c|c|}
\hline Özsoy [267] & Turkish & Poster & Review & $\begin{array}{l}\text { Biometric analysis of PC } \\
\text { publications in the period } \\
\text { 2000-2016. }\end{array}$ & $\begin{array}{l}\text { It was observed that the number of publications in the field } \\
\text { of PC increased significantly after } 2006 \text {. The USA and the UK } \\
\text { are pioneers in the number of publications. }\end{array}$ \\
\hline $\begin{array}{l}\text { Mutafoğlu } \\
\text { et al [51] }\end{array}$ & Turkish & Poster & Cross-sectional & $\begin{array}{l}\text { Attitude of oncologists } \\
\text { about PC in cancer. }\end{array}$ & $\begin{array}{l}\text { Almost } 97 \% \text { of the participants find the PC services provided } \\
\text { to patients with cancer in our country are inadequate. } \\
\text { Despite supportive treatments for physical symptoms, } \\
\text { psychosocial support is insufficient. }\end{array}$ \\
\hline $\begin{array}{l}\text { Topaloğlu et al } \\
\text { [149] }\end{array}$ & Turkish & Poster & Cross-sectional & $\begin{array}{l}\text { Factors affecting pain } \\
\text { control in patients with } \\
\text { cancer pain. }\end{array}$ & $\begin{array}{l}\text { About } 58 \% \text { of the patients had pain for more than } 2 \text { months. } \\
64 \% \text { of the patients with poor pain control did not use regular } \\
\text { analgesics. The most common reason for not using regular } \\
\text { analgesics was 'not being recommended that analgesics } \\
\text { should be used regularly'. }\end{array}$ \\
\hline $\begin{array}{l}\text { Çakır and } \\
\text { Uzuner [160] }\end{array}$ & Turkish & Poster & Case series & $\begin{array}{l}\text { Nutritional support } \\
\text { result of children with } \\
\text { nasogastric tube. }\end{array}$ & $\begin{array}{l}\text { In case of weight loss among children with cancer, if nutrition } \\
\text { cannot be provided orally, it should be provided via the } \\
\text { nasogastric (NG) route. NG feeding is a safe, cheap, and } \\
\text { uncomplicated nutritional care. }\end{array}$ \\
\hline $\begin{array}{l}\text { Tosun et al } \\
\text { [183] }\end{array}$ & Turkish & Poster & Cross-sectional & $\begin{array}{l}\text { Nutritional support of } \\
\text { patients with lung cancer } \\
\text { receiving PC: difficulties } \\
\text { experienced by patients } \\
\text { and caregivers. }\end{array}$ & $\begin{array}{l}\text { Caregivers are anxious about the nutrition of their patients } \\
\text { and they thought that alternative nutrition methods were } \\
\text { not sufficient. Bed dependence, nausea, vomiting, anorexia, } \\
\text { cachexia, pain, shortness of breath and personality changes } \\
\text { were the most frequent symptoms. Family structure and } \\
\text { cultural differences may affect individual differences in } \\
\text { nutrition-related patients. Nutritional support should be } \\
\text { added to planning of care of patients with cancer. }\end{array}$ \\
\hline $\begin{array}{l}\text { Yıldız Savran } \\
\text { et al [154] }\end{array}$ & Turkish & Poster & Cross-sectional & $\begin{array}{l}\text { Symptom clusters among } \\
\text { children with cancer. }\end{array}$ & $\begin{array}{l}\text { Age, time to diagnosis and number of chemotherapy } \\
\text { cycles affect the symptoms of the children. The number of } \\
\text { symptoms increased with higher age, longer time to diagnosis } \\
\text { and higher number of chemotherapy cycles. Children who } \\
\text { had their treatment in the hospital experienced physical } \\
\text { symptoms more frequently. The most frequent symptoms } \\
\text { were low appetite, irritability and difficulty in concentration. }\end{array}$ \\
\hline $\begin{array}{l}\text { Söğütlü Çetin } \\
\text { and Kuran } \\
\text { Akburak [155] }\end{array}$ & Turkish & Poster & Cross-sectional & $\begin{array}{l}\text { Symptoms experienced } \\
\text { by patients receiving } \\
\text { chemotherapy and factors } \\
\text { affecting these symptoms. }\end{array}$ & $\begin{array}{l}\text { The symptoms of fatigue and anxiety were found to be } \\
\text { significantly higher among inpatients. Whereas constipation, } \\
\text { alopecia, mouth problems were more frequent among } \\
\text { outpatients. }\end{array}$ \\
\hline Akyüz [211] & Turkish & Poster & Cross-sectional & $\begin{array}{l}\text { PC practices for cancer } \\
\text { patients. }\end{array}$ & $\begin{array}{l}\text { Satisfaction level of cancer patients treated in hospitals with } \\
\text { PCU was higher than others without PCU. Patients receiving } \\
\text { treatment in the PCU do not want to go another hospital, and } \\
\text { they want to receive psychological support as well as medical } \\
\text { support during the treatment. }\end{array}$ \\
\hline $\begin{array}{l}\text { Kuşçu et al } \\
\text { [249] }\end{array}$ & Turkish & Poster & $\begin{array}{l}\text { Prospective/ } \\
\text { cross-sectional }\end{array}$ & $\begin{array}{l}\text { Benefits of Palliative } \\
\text { Performance Scale (PPS) } \\
\text { for planning end-of-life } \\
\text { care for patients. }\end{array}$ & $\begin{array}{l}\text { Palliative Performance Scale can be used as a powerful tool } \\
\text { in predicting prognosis and survival together with clinical and } \\
\text { laboratory findings. }\end{array}$ \\
\hline
\end{tabular}


Supplementary Table 1. Details of the included studies. (Continued).

\begin{tabular}{|c|c|c|c|c|c|}
\hline $\begin{array}{l}\text { Alkan et al } \\
\text { [50] }\end{array}$ & Turkish & Poster & Cross-sectional & $\begin{array}{l}\text { Opinions and competency } \\
\text { of internal medicine } \\
\text { residents on pain } \\
\text { management in cancer } \\
\text { patients. }\end{array}$ & $\begin{array}{l}\text { Pain management for cancer patients is an important issue } \\
\text { that internal medicine residents should learn in the training } \\
\text { process. The rotation period should be appropriate with the } \\
\text { relevant education and medical experience. }\end{array}$ \\
\hline $\begin{array}{l}\text { Demir and } \\
\text { Yılmaz [307] }\end{array}$ & Turkish & Poster & Cross-sectional & $\begin{array}{l}\text { Expectations of oncology } \\
\text { patients and their } \\
\text { relatives from home care } \\
\text { services. }\end{array}$ & $\begin{array}{l}\text { Oncology patients do not benefit from home care services } \\
\text { at an adequate and desired level, and home care services are } \\
\text { yet to be effective and available at meeting the expectations } \\
\text { of oncology patients. }\end{array}$ \\
\hline $\begin{array}{l}\text { Dayanç et al } \\
{[147]}\end{array}$ & Turkish & Poster & Cross-sectional & $\begin{array}{l}\text { Analysis of self- } \\
\text { symptoms and problems } \\
\text { of patients discharged } \\
\text { after chemotherapy and } \\
\text { counseled by telephone. }\end{array}$ & $\begin{array}{l}\text { The most common problem for consultation were nausea } \\
(29.1 \%) \text {, vomiting }(19.5 \%) \text {, diarrhoea }(14.5 \%) \text {, pain }(10.8 \%) \text {, } \\
\text { constipation }(9.16 \%) \text { and loss of appetite }(4.16 \%) \text {. }\end{array}$ \\
\hline $\begin{array}{l}\text { Abca Yılmazer } \\
\text { and Okyayüz } \\
{[227]}\end{array}$ & Turkish & Poster & Interventional & $\begin{array}{l}\text { Information-focused } \\
\text { pain and depression } \\
\text { assessment in patients } \\
\text { with bone metastasis } \\
\text { during palliative } \\
\text { radiotherapy. }\end{array}$ & $\begin{array}{l}\text { Patients with bone metastasis were divided into two } \\
\text { groups. Both were offered appropriate analgesic treatment } \\
\text { and palliative radiotherapy to painful bone metastases. } \\
\text { Psychological pain control methods (relaxation, breathing } \\
\text { exercises and cognitive therapy) were recommended to } \\
\text { interventional group. Semi-structured interview form were } \\
\text { applied and the visual analogue scale for pain assessment and } \\
\text { Beck Depression Scale for the evaluation of depression were } \\
\text { used for comparing interventional and control groups. Post- } \\
\text { treatment Beck Depression Scale levels were found to be } \\
\text { higher in the interventional group than in the control group. } \\
\text { We recommended to use psychological methods in addition } \\
\text { to pharmacological methods. }\end{array}$ \\
\hline $\begin{array}{l}\text { Özçelik et al } \\
\text { [158] }\end{array}$ & Turkish & Poster & Cross-sectional & $\begin{array}{l}\text { Determination of family } \\
\text { satisfaction levels of } \\
\text { advanced cancer patients. }\end{array}$ & $\begin{array}{l}\text { The family satisfaction total scale mean score was } 10.7676 \\
\pm 13.28 \text {. } \\
\text { Other subscale mean scores were as follows: getting } \\
\text { information as } 10.03 \pm 13.85 \text {, access to care as } 11.20 \pm \\
14.82 \text {, physical care as } 10.64 \pm 14.21 \text {, psychosocial care as } \\
11.46 \pm 14.30 \text {. }\end{array}$ \\
\hline $\begin{array}{l}\text { Demirkaya } \\
\text { et al [159] }\end{array}$ & Turkish & Poster & Cross-sectional & $\begin{array}{l}\text { Evaluation of pain } \\
\text { experiences by paediatric } \\
\text { oncology patients. }\end{array}$ & $\begin{array}{l}\text { The pain complaint rates are high in paediatric oncology } \\
\text { practice. The quality of life and treatment compliance of } \\
\text { children with cancer is affected by many factors, mostly due } \\
\text { to pain. }\end{array}$ \\
\hline $\begin{array}{l}\text { Görgün et al } \\
\text { [130] }\end{array}$ & Turkish & Poster & Cross-sectional & $\begin{array}{l}\text { Pain assessment and } \\
\text { palliation in patients with } \\
\text { metastatic cancer. }\end{array}$ & $\begin{array}{l}\text { It was aimed to explore pain status of patients and propose } \\
\text { an algorithm for treatment approach in patients with } \\
\text { advanced stage cancer who were followed up in hospital, and } \\
\text { to emphasise the importance of questioning the patient's } \\
\text { pain. In addition, this importance of the pain, even in } \\
\text { inpatients, reveals the necessity of careful pain management } \\
\text { in outpatient follow-up. Pain palliation, which is one of the } \\
\text { cornerstones of palliative treatment, should always be kept in } \\
\text { mind in the treatment of cancer patients. }\end{array}$ \\
\hline
\end{tabular}


Supplementary Table 1. Details of the included studies. (Continued).

\begin{tabular}{|c|c|c|c|c|c|}
\hline $\begin{array}{l}\text { Urlu et al } \\
\text { [131] }\end{array}$ & Turkish & Poster & Cross-sectional & $\begin{array}{l}\text { Interventional pain } \\
\text { management among } \\
\text { oncology patients. }\end{array}$ & $\begin{array}{l}\text { The vast majority of cancer patients can be treated with } \\
\text { appropriate medical treatment for pain. Interventional } \\
\text { methods should be tried in patients who do not respond to } \\
\text { medical treatment. For this, palliative treatment teams should } \\
\text { work with a multidisciplinary approach. }\end{array}$ \\
\hline $\begin{array}{l}\text { Aktaş et al } \\
\text { [308] }\end{array}$ & Turkish & Poster & Case report & $\begin{array}{l}\text { Nursing care for a patient } \\
\text { with cholangiocarcinoma. }\end{array}$ & $\begin{array}{l}\text { PC was planned with a multidisciplinary team in hospital and } \\
\text { coordinated support continued at home. During inpatient } \\
\text { stay ascites palliation, pain control, nutrition and antiemetics } \\
\text { were planned and his performance and quality of life } \\
\text { increased. }\end{array}$ \\
\hline $\begin{array}{l}\text { Tiryaki et al } \\
\text { [309] }\end{array}$ & Turkish & Poster & Case report & $\begin{array}{l}\text { The role of the nurse in } \\
\mathrm{PC} \text { in a patient with lung } \\
\text { cancer. }\end{array}$ & $\begin{array}{l}\text { Patients and their relatives were trained on the management } \\
\text { of nausea and vomiting and sleep issues and oral health. The } \\
\text { onset, location, type, of pain, were determined. Analgesics } \\
\text { were applied. The patient's quality of life was improved by } \\
\text { monitoring the pain during the treatment. }\end{array}$ \\
\hline Demiral [310] & Turkish & Poster & Case report & $\begin{array}{l}\text { Palliative nursing care } \\
\text { for a patient with } \\
\text { desmoplastic small round } \\
\text { cell tumour. }\end{array}$ & $\begin{array}{l}\text { There have been attempts to relieve pain, prevent infection, } \\
\text { provide nutrition, prevent constipation, relieve anxiety and } \\
\text { fears, and fatigue. The PC has improved patient quality of life. }\end{array}$ \\
\hline $\begin{array}{l}\text { Üçgül } \\
\text { Çavuşoğlu } \\
\text { et al [200] }\end{array}$ & Turkish & Poster & Cross-sectional & $\begin{array}{l}\text { The treatments and tests } \\
\text { performed in the last } 2 \\
\text { weeks for patients with } \\
\text { terminal cancer before } \\
\text { death. }\end{array}$ & $\begin{array}{l}\text { Infections and liver failure were leading cause of death in the } \\
\text { last } 2 \text { weeks before death. Radiological examinations, total } \\
\text { parenteral nutrition, albumin transfusion, enteral feeding, } \\
\text { blood transfusion, pain relief and terminal sedation were } \\
\text { noteworthy procedures found during this period. }\end{array}$ \\
\hline $\begin{array}{l}\text { Doruk et al } \\
\text { [215] }\end{array}$ & Turkish & Poster & Cross-sectional & $\begin{array}{l}\text { Opinions of terminal } \\
\text { cancer patients and } \\
\text { their caregivers about } \\
\text { medical approaches and } \\
\text { treatments applied in the } \\
\text { hospital. }\end{array}$ & $\begin{array}{l}\text { Generally, people other than the patient make the decision } \\
\text { for hospitalisation in the terminal period. Informing } \\
\text { patients and their relatives about terminal period care and } \\
\text { their participation in decisions is important. An empathic } \\
\text { and relevant approach is expected from healthcare staff. } \\
\text { Psychosocial support is necessary for both the patient and } \\
\text { their relatives. }\end{array}$ \\
\hline $\begin{array}{l}\text { Koyuncu and } \\
\text { Aksu [132] }\end{array}$ & Turkish & Poster & Interventional & $\begin{array}{l}\text { The effect of morphine } \\
\text { sulphate infusion on pain } \\
\text { control in terminal cancer } \\
\text { patients. }\end{array}$ & $\begin{array}{l}\text { The median visual analogue scale pain levels of the patients } \\
\text { were found to be } 8.5(7-10) \text { before morphine sulphate } \\
\text { administration and } 6.5(4-7) \text { after morphine sulphate } \\
\text { administration. }\end{array}$ \\
\hline Köse F [251] & Turkish & Poster & Cross-sectional & $\begin{array}{l}\text { The indications and } \\
\text { complications of terminal } \\
\text { sedation with morphine } \\
\text { and midazolam in } \\
\text { emergency and elective } \\
\text { conditions. }\end{array}$ & $\begin{array}{l}\text { The aetiology for the refractory symptoms was dyspnoea, } \\
\text { delirium and intractable pain for patients in elective and } \\
\text { immediate sedation groups as follows: } 51 \% \text { versus } 47 \% \text {, } \\
10 \% \text { versus } 19 \% \text { and } 38 \% \text { versus } 33 \% \text {. Thorax region served } \\
\text { primary site for the significant percentage of the patients } \\
\text { with rates of } 61 \% \text { and } 57 \% \text { in elective and immediate } \\
\text { sedation groups. The number of patients with intractable } \\
\text { symptom of the delirium in immediate group (19\%) } \\
\text { notably higher than elective group ( } 9 \% \text { ). Time between last } \\
\text { chemotherapy and start of the palliative sedation was } 71 \\
\text { versus } 97 \text { days in elective and immediate group, respectively. }\end{array}$ \\
\hline
\end{tabular}


Supplementary Table 1. Details of the included studies. (Continued).

\begin{tabular}{|c|c|c|c|c|c|}
\hline $\begin{array}{l}\text { Göksel and } \\
\text { Doğan [140] }\end{array}$ & Turkish & Poster & $\begin{array}{l}\text { Retrospective / } \\
\text { cross-sectional }\end{array}$ & $\begin{array}{l}\text { Home Health Services } \\
\text { in Turkey (HHS) } \\
\text { for gastrointestinal } \\
\text { malignancies. }\end{array}$ & $\begin{array}{l}\text { After neurological and psychiatric diseases, cardiovascular } \\
\text { diseases and orthopaedic diseases, cancer patients constitute } \\
\text { the fourth group disease that receives HHS most frequently. } \\
\text { HHS started with a total of } 593 \text { teams in } 2011 \text { and increased } \\
\text { to } 662 \text { teams in } 2017 \text {. Total number of visits made in } 2011 \\
\text { was } 344,014 \text {, and visit number increased to } 10,917,965 \text { in } \\
2017 \text {. } \\
7,278 \text { visits were made for patients with cancer in } 2011 \text {, } \\
74,261 \text { in } 2017 \text {. } \\
\text { The total number of patient visits with GIS malignancy was } \\
89,389 \text { during } 7 \text { years. }\end{array}$ \\
\hline $\begin{array}{l}\text { Almaca et al } \\
\text { [184] }\end{array}$ & Turkish & Poster & Case control & $\begin{array}{l}\text { Effects of enteral } \\
\text { nutrition (EN) and } \\
\text { parenteral nutrition (PN) } \\
\text { on clinical outcomes of } \\
\text { cancer patients. }\end{array}$ & $\begin{array}{l}\text { There was no difference between EN and PN in terms } \\
\text { of overall mortality. Considering the patients who need } \\
\text { intensive care during their hospitalisation; the rate of PN was } \\
\text { significantly higher than EN. Thrombosis rates were similar } \\
\text { between the two groups, but infectious complications were } \\
\text { higher in the PN group. }\end{array}$ \\
\hline $\begin{array}{l}\text { Arias-Casais } \\
\text { et al [311] }\end{array}$ & English & Book & $\begin{array}{l}\text { Mixed-method; } \\
\text { systematic } \\
\text { review, surveys, } \\
\text { interviews }\end{array}$ & $\begin{array}{l}\text { To provide an updated } \\
\text { analysis on the } \\
\text { development and } \\
\text { integration of PC across } \\
\text { Europe. }\end{array}$ & $\begin{array}{l}\text { The funds are allocated for PC from the Turkish health } \\
\text { budget. PC is included in the list of health services provided } \\
\text { at the primary care level and in the basic package of health } \\
\text { services. The PC services in Turkey are } 0.2 \text { per } 100,000 \\
\text { inhabitants. None of the medical and nursing schools } \\
\text { offering specific mandatory PC courses in Turkey. Opioid } \\
\text { consumption per capita in morphine equivalent in } 2017 \text { was } \\
1.3 \text { mg. PC resources for children were very limited. }\end{array}$ \\
\hline $\begin{array}{l}\text { Kömürcü and } \\
\text { Türkiye'de } \\
\text { Palyatif Bakım } \\
\text { [17] }\end{array}$ & Turkish & Book & Review & $\begin{array}{l}\text { This chapter provide } \\
\text { overview of PC for cancer } \\
\text { in Turkey during } 2009 .\end{array}$ & $\begin{array}{l}\text { As in many developing countries, the current status of PC in } \\
\text { our country is not yet at the desired level. The main problems } \\
\text { for the development are lack of adequately trained personnel, } \\
\text { Opiophobia in the public and healthcare workers, lack of laws } \\
\text { and regulations regarding PC, and insufficient } \\
\text { financial support. }\end{array}$ \\
\hline Utku et al [44] & English & Book chapter & Review & $\begin{array}{l}\text { This chapter gives the } \\
\text { narratives of Turkey's } \\
\text { experience, challenges } \\
\text { and successes for the PC } \\
\text { efforts. }\end{array}$ & $\begin{array}{l}\text { After the } 5 \text { years of the Pallia-Turk Project, Turkey has } 226 \\
\text { PC services, } 947 \text { home-care teams, } 21,696 \text { family physicians } \\
\text { and nurses serving for primary level care. Oral morphine } \\
\text { tablets with different dosage formulas have been produced } \\
\text { by } 2015 \text {. The opioid accessibility and usage have increased } \\
\text { due to reimbursement by the Social Security Institutes in } \\
\text { the country within the last years. Legislation regarding the } \\
\text { integration of PC services at the primary level, integration } \\
\text { of family physicians to home care teams, patients' rights for } \\
\text { rejection treatments, reimbursement of PC services in-home } \\
\text { care and in the hospital were published. }\end{array}$ \\
\hline Temelli [312] & Turkish & Thesis & Cross-sectional & $\begin{array}{l}\text { To identify the } \\
\text { perceptions of palliative } \\
\text { nurses about death and } \\
\text { determining PC practices. }\end{array}$ & $\begin{array}{l}\text { Palliative nurses perceive death as a natural and inevitable } \\
\text { process and that as long as their working period increases, } \\
\text { they become desensitised. }\end{array}$ \\
\hline
\end{tabular}


Supplementary Table 1. Details of the included studies. (Continued).

\begin{tabular}{|c|c|c|c|c|c|}
\hline Topkaya [313] & Turkish & Thesis & Cross-sectional & $\begin{array}{l}\text { To determine the } \\
\text { PC needs of cancer } \\
\text { patients and to examine } \\
\text { the knowledge and } \\
\text { expectations of patients } \\
\text { and their families about } \\
\text { PC. }\end{array}$ & $\begin{array}{l}\text { Seventy-six point four percent of the patients and } 60 \% \text { of } \\
\text { their families were not aware of palliative/supportive care. }\end{array}$ \\
\hline Yılmaz [314] & Turkish & Thesis & Cross-sectional & $\begin{array}{l}\text { To determine the } \\
\text { frequency of symptomatic } \\
\text { manifestations in cancer } \\
\text { patients treated in } \\
\text { Palliative Care Unit and } \\
\text { examine changes in the } \\
\text { frequency after PC. }\end{array}$ & $\begin{array}{l}\text { A statistically significant difference was found between } \\
\text { admission and discharge values in terms of the severity of } \\
\text { pain, fatigue, nausea, sadness, anxiety, insomnia, anorexia, } \\
\text { shortness of breath and paresthesia in hands. }\end{array}$ \\
\hline Arkın [315] & Turkish & Thesis & Cross-sectional & $\begin{array}{l}\text { To evaluate the } \\
\text { psychosocial features of } \\
\text { family caregivers of PC } \\
\text { patients at an inpatient } \\
\text { clinic by examining } \\
\text { perceived social support, } \\
\text { depression and anxiety. }\end{array}$ & $\begin{array}{l}\text { The increase in social support perceptions of caregivers of PC } \\
\text { patients was associated with a decrease in the symptoms of } \\
\text { anxiety and depression. }\end{array}$ \\
\hline Sağlam [316] & Turkish & Thesis & Methodological & $\begin{array}{l}\text { To determine the needs } \\
\text { of family members who } \\
\text { care for palliative patients } \\
\text { regarding the care and } \\
\text { treatment processes. }\end{array}$ & $\begin{array}{l}\text { The needs of the caregivers in relation to care and treatment } \\
\text { processes differed according to their socio-demographic and } \\
\text { care burden characteristics. Family Needs Scale is a valid } \\
\text { and reliable measurement instrument that can be applied to } \\
\text { palliative patients' relatives in our country. }\end{array}$ \\
\hline Erdem [205] & Turkish & Thesis & $\begin{array}{l}\text { Prospective } \\
\text { cohort }\end{array}$ & $\begin{array}{l}\text { To monitor individuals } \\
\text { diagnosed with life- } \\
\text { threatening diseases in a } \\
\text { comprehensive PC centre } \\
\text { run by family physicians } \\
\text { and to evaluate their } \\
\text { quality of life and related } \\
\text { factors with early PC. }\end{array}$ & $\begin{array}{l}\text { All subscale mean scores of quality of life assessment were } \\
\text { higher in the 6th month of the study. While there was a } \\
\text { significant positive correlation between the time from } \\
\text { diagnosis to PC application and the quality of life in the } \\
\text { energy and pain sub-dimensions, no significant correlation } \\
\text { was found between the time from diagnosis to PC } \\
\text { application and survival. Patients should be informed at the } \\
\text { earliest stage. }\end{array}$ \\
\hline Taş [317] & Turkish & Thesis & $\begin{array}{l}\text { Prospective } \\
\text { cohort }\end{array}$ & $\begin{array}{l}\text { To investigate the effects } \\
\text { of nutritional patterns on } \\
\text { activity and performance } \\
\text { scores, symptom levels, } \\
\text { laboratory parameters, } \\
\text { anthropometric } \\
\text { measurements and } \\
\text { mortality in PC patients } \\
\text { with a high malnutrition } \\
\text { risk score. }\end{array}$ & $\begin{array}{l}\text { Among PC patients with malnutrition the patients who } \\
\text { have lower activity and performance scores need more } \\
\text { parenteral nutrition, and parenteral nutrition need, edema } \\
\text { and poor performance status are independent determinants } \\
\text { of mortality. }\end{array}$ \\
\hline
\end{tabular}


Supplementary Table 1. Details of the included studies. (Continued).

\begin{tabular}{|c|c|c|c|c|c|}
\hline Düzgün [91] & Turkish & Thesis & Interventional & $\begin{array}{l}\text { To investigate the effect } \\
\text { of music on pain, anxiety } \\
\text { comfort and functional } \\
\text { capacity of cancer } \\
\text { patients received care in a } \\
\text { PC unit. }\end{array}$ & $\begin{array}{l}\text { Turkish classical music therapy improved pain, anxiety, } \\
\text { comfort, functional capacity, and the control of vital signs in } \\
\text { cancer patients cared in the PC unit. }\end{array}$ \\
\hline Tanıl [318] & Turkish & Thesis & Cross-sectional & $\begin{array}{l}\text { To evaluate the opinions } \\
\text { of the oncology patients } \\
\text { in the palliative period } \\
\text { about their experiences } \\
\text { of bad news interviews } \\
\text { and communication } \\
\text { preferences for receiving } \\
\text { bad news in addition } \\
\text { to death anxiety and } \\
\text { attitudes towards death. }\end{array}$ & $\begin{array}{l}\text { The perceptions, expectations and attitudes of the palliative } \\
\text { oncology patients on bad news were evaluated. }\end{array}$ \\
\hline Ardıç [319] & Turkish & Thesis & Cross-sectional & $\begin{array}{l}\text { To investigate if there } \\
\text { is a significant relation } \\
\text { between palliative stage } \\
\text { cancer relatives' self- } \\
\text { compassion levels and } \\
\text { psychological resilience, } \\
\text { quality of life, depression, } \\
\text { anxiety and stress. }\end{array}$ & $\begin{array}{l}\text { Receiving information support had a significant effect on } \\
\text { psychological resilience and receiving sufficient support had } \\
\text { a significant effect on quality of life. }\end{array}$ \\
\hline Duman [320] & Turkish & Thesis & Cross-sectional & $\begin{array}{l}\text { To determine the effect } \\
\text { of the opinions of the } \\
\text { relatives of the inpatients } \\
\text { in the Palliative Care Unit } \\
\text { on the caregiver burden. }\end{array}$ & $\begin{array}{l}\text { The opinions of the relatives of the patients about PC did not } \\
\text { significantly affect the caregiver burden. However, caregiver } \\
\text { burden was significantly affected according to the patient's } \\
\text { view of being peaceful in the hospital. }\end{array}$ \\
\hline Damak [321] & Turkish & Thesis & Cross-sectional & $\begin{array}{l}\text { To determine the nurses' } \\
\text { perceptions of good death } \\
\text { and their knowledge } \\
\text { about PC. }\end{array}$ & $\begin{array}{l}\text { It was determined that the nurses' knowledge of PC was } \\
\text { moderate and their perceptions of good death were high. }\end{array}$ \\
\hline $\begin{array}{l}\text { Karakaya } \\
\text { [322] }\end{array}$ & Turkish & Thesis & Cross-sectional & $\begin{array}{l}\text { To evaluate the quality } \\
\text { of life of caregivers } \\
\text { (family members) of PC } \\
\text { patients and to determine } \\
\text { the factors affecting } \\
\text { the quality of life of } \\
\text { caregivers. }\end{array}$ & $\begin{array}{l}\text { Quality of life levels of those with high age, those with low } \\
\text { education level, those with low income and those with } \\
\text { children were lower. }\end{array}$ \\
\hline Kurtgöz [323] & Turkish & Thesis & Interventional & $\begin{array}{l}\text { To determine the effect } \\
\text { of nursing care on } \\
\text { spiritual well-being and } \\
\text { hopefulness in relatives of } \\
\text { PC patients. }\end{array}$ & $\begin{array}{l}\text { The provision of nursing care based on the theory of } \\
\text { Watson's Human Caring decreased the severity of } \\
\text { hopelessness in the patient relatives; however, it was found } \\
\text { that it did change their spiritual well-being levels. }\end{array}$ \\
\hline
\end{tabular}


Supplementary Table 1. Details of the included studies. (Continued).

\begin{tabular}{|c|c|c|c|c|c|}
\hline Tarakçı [324] & Turkish & Thesis & Cross-sectional & $\begin{array}{l}\text { To determine the factors } \\
\text { affecting the long-term } \\
\text { hospitalisation and } \\
\text { discharge status of the } \\
\text { patients hospitalised in } \\
\text { a PC service of a tertiary } \\
\text { hospital for a period of } \\
1 \text { year, to determine } \\
\text { preventable and curable } \\
\text { conditions, to prevent the } \\
\text { morbidity and mortality } \\
\text { caused by unnecessary } \\
\text { health expenditures and } \\
\text { long hospitalisation. }\end{array}$ & $\begin{array}{l}\text { Majority of patients who were admitted to the palliative } \\
\text { service were cancer patients. Factors that increase the } \\
\text { duration of hospitalisation were; the presence of infection, } \\
\text { polypharmacy and pressure sores, and the use of antibiotics } \\
\text { and analgesics. Factors related to discharge status were; } \\
\text { infection status ( } p<0.01) \text {, antibiotic use status ( } p: 0.02) \text {, diet } \\
(p<0.01) \text { and opioid use }(p<0.01) \text {. }\end{array}$ \\
\hline Demirgil [82] & Turkish & Thesis & Cross-sectional & $\begin{array}{l}\text { To examine the } \\
\text { knowledge levels of } \\
\text { emergency service } \\
\text { employees concerning } \\
\text { PC, as well as their } \\
\text { educational background } \\
\text { and approach to end-of- } \\
\text { life care and to investigate } \\
\text { whether that has a } \\
\text { correlation with ethical } \\
\text { sensitivity or not. }\end{array}$ & $\begin{array}{l}\text { Majority of the participants ( } 63 \%) \text { had not received PC } \\
\text { training before. While the PC score average was found to be } \\
49.10 \pm 8.25 \text {; the total score average of the Ethical Sensitivity } \\
\text { Scale was found to be } 78.73 \pm 20.97 \text {. }\end{array}$ \\
\hline Çelik [325] & Turkish & Thesis & Interventional & $\begin{array}{l}\text { To investigate the effects } \\
\text { of bright white light } \\
\text { application on fatigue and } \\
\text { sleep quality in cancer } \\
\text { patients receiving PC. }\end{array}$ & $\begin{array}{l}\text { The application of bright white light reduces the fatigue } \\
\text { levels and increases sleep quality and sleep duration of } \\
\text { cancer patients receiving PC. There was no positive or } \\
\text { negative late effects of light on fatigue level and sleep quality } \\
\text { in the period following bright white light application. }\end{array}$ \\
\hline $\begin{array}{l}\text { AÇalışkan } \\
\text { [209] }\end{array}$ & Turkish & Thesis & Cost analysis & $\begin{array}{l}\text { To conduct a cost analysis } \\
\text { of PC as a new service } \\
\text { branch in healthcare field. }\end{array}$ & $\begin{array}{l}\text { Total cost of the Palliative Care Center was TRY } \\
1.034 .235,26.36 \% \text { of the total cost consisted of raw material } \\
\text { and supply costs, } 33 \% \text { staff costs, } 20 \% \text { external benefits and } \\
\text { services, } 7 \% \text { pubic shares and } 3 \% \text { depreciation and wear } \\
\text { and tear allowance. The centre's income could not meet its } \\
\text { expenses, and it lost TRY } 158.235,26 \text { in total. As income was } \\
\text { calculated as same-day treatment, the centre lost TRY } 54,19 \\
\text { per day. }\end{array}$ \\
\hline $\begin{array}{l}\text { Akbulut Şahin } \\
\text { [256] }\end{array}$ & Turkish & Thesis & Qualitative & $\begin{array}{l}\text { To investigate the level of } \\
\text { benefiting from religious } \\
\text { coping strategies by the } \\
\text { relatives of cancer patient. }\end{array}$ & $\begin{array}{l}\text { It was determined that the relatives of the patients used } \\
\text { religious coping strategies widely and thought that it was } \\
\text { advantageous to benefit from religious coping strategies. } \\
\text { Benefiting from religious coping strategies in the treatment } \\
\text { process might produce positive results for relatives of } \\
\text { patients. }\end{array}$ \\
\hline
\end{tabular}


Supplementary Table 1. Details of the included studies. (Continued).

\begin{tabular}{|c|c|c|c|c|c|}
\hline Özhan [326] & Turkish & Thesis & Cross-sectional & $\begin{array}{l}\text { To measure the } \\
\text { depression levels, } \\
\text { perceived social support } \\
\text { and the quality of life } \\
\text { of relatives of terminal } \\
\text { period patients. }\end{array}$ & $\begin{array}{l}\text { Economical conditions get worse as the points of the quality } \\
\text { of life decrease. The correlation between the educational } \\
\text { status and quality of life points is positive. }\end{array}$ \\
\hline Adanır [327] & Turkish & Thesis & Cross-sectional & $\begin{array}{l}\text { To determine the } \\
\text { compassion fatigue and } \\
\text { coping styles with stress } \\
\text { of nurses working on } \\
\text { oncology and PC patients. }\end{array}$ & $\begin{array}{l}\text { As the compassion fatigue of nurses increased, compassion } \\
\text { satisfaction decreased but burnout increased. }\end{array}$ \\
\hline $\begin{array}{l}\text { Balcıoğlu } \\
\text { [328] }\end{array}$ & Turkish & Thesis & Cross-sectional & $\begin{array}{l}\text { To evaluate the nutritional } \\
\text { status of } 65 \text { years and } \\
\text { older patients followed- } \\
\text { up in the PC unit. }\end{array}$ & $\begin{array}{l}\text { Malnutrition is highly prevalent in patients with the need for } \\
\text { PC. }\end{array}$ \\
\hline $\begin{array}{l}\text { Gürel } \\
\text { Yavuzdemir } \\
{[210]}\end{array}$ & Turkish & Thesis & Cross-sectional & $\begin{array}{l}\text { To examine PC services in } \\
\text { a PC centre. }\end{array}$ & $\begin{array}{l}\text { Families' satisfaction with pain management was effective in } \\
\text { choosing post-discharge care place and families wanted to } \\
\text { choose a PC centre. } 81.0 \% \text { of the families had no awareness } \\
\text { of PC and } 19.0 \% \text { of them had awareness. In research, direct } \\
\text { cost of illness was examined. The average unit cost was } \\
22.128 \text { TL. The unit cost of a day in hospital was found as } \\
391 \text { TL. }\end{array}$ \\
\hline Altay [329] & Turkish & Thesis & $\begin{array}{l}\text { Quasi- } \\
\text { experimental }\end{array}$ & $\begin{array}{l}\text { To determine the effect } \\
\text { of PC training on the } \\
\text { knowledge level of nurses } \\
\text { about PC for nurses } \\
\text { working in oncology } \\
\text { wards and nurses who } \\
\text { care for cancer patients. }\end{array}$ & $\begin{array}{l}\text { The PC training effectively improved the knowledge level of } \\
\text { nurses. }\end{array}$ \\
\hline $\begin{array}{l}\text { Uslu Şahan } \\
\text { [330] }\end{array}$ & Turkish & Thesis & $\begin{array}{l}\text { Mixed method; } \\
\text { RCT \& } \\
\text { qualitative }\end{array}$ & $\begin{array}{l}\text { To determine the effect } \\
\text { of interprofessional } \\
\text { simulation training on } \\
\text { PC competencies to } \\
\text { gynaecologic oncology, } \\
\text { interdisciplinary } \\
\text { education perceptions } \\
\text { and teamwork attitudes } \\
\text { of the students and to } \\
\text { determine opinions, } \\
\text { thoughts and suggestions } \\
\text { of students about } \\
\text { the use of simulation } \\
\text { in interprofessional } \\
\text { gynaecologic oncology PC } \\
\text { training. }\end{array}$ & $\begin{array}{l}\text { Training programmes which are used together with high } \\
\text { fidelity simulation and hybrid simulations applications } \\
\text { in interdisciplinary training should be integrated into } \\
\text { the undergraduate education curriculums of the future } \\
\text { cooperating health professions. }\end{array}$ \\
\hline
\end{tabular}


Supplementary Table 1. Details of the included studies. (Continued).

\begin{tabular}{|c|c|c|c|c|c|}
\hline Kaya [331] & Turkish & Thesis & Cross-sectional & $\begin{array}{l}\text { To renew and reorganise } \\
\text { physicians' training } \\
\text { schedules according to } \\
\text { any consultation required } \\
\text { by a physician in Palliative } \\
\text { Care Service. }\end{array}$ & $\begin{array}{l}\text { The average of consultations for a patient was } 5.48 \pm 7.29 \\
\text { and the maximum number of consultations was } 50 ; 19.9 \% \\
\text { of patients did not require any consultation, } 12.1 \% \text { had one } \\
\text { consultation, } 14.2 \% \text { had two consultations. In } 84.3 \% \text { of the } \\
\text { cases, the reasons for consultation were for diagnostic and } \\
\text { treatment purposes and in } 6.54 \% \text { for preoperative interviews. }\end{array}$ \\
\hline Metin [204] & Turkish & Thesis & Cross-sectional & $\begin{array}{l}\text { To investigate the } \\
\text { relationship between } \\
\text { the health literacy level } \\
\text { of PC service patient } \\
\text { companions and patient } \\
\text { care results and survival } \\
\text { status of the patients. }\end{array}$ & $\begin{array}{l}\text { Health literacy of the companions of patients receiving PC is } \\
\text { associated with bedsore occurrence and survival. }\end{array}$ \\
\hline $\begin{array}{l}\text { Eskigülek } \\
\text { [332] }\end{array}$ & Turkish & Thesis & Methodological & $\begin{array}{l}\text { To investigate the views } \\
\text { of the PC patients and } \\
\text { the nurses working in this } \\
\text { field about dignified care } \\
\text { and to evaluate Turkish } \\
\text { validity and reliability } \\
\text { of the Patient Dignity } \\
\text { Inventory. }\end{array}$ & $\begin{array}{l}\text { It was determined that the Patient Dignity Inventory is a valid } \\
\text { and reliable scale for Turkish society. }\end{array}$ \\
\hline Güçlü [333] & Turkish & Thesis & Cross-sectional & $\begin{array}{l}\text { To investigate the effects } \\
\text { of hand grip strength } \\
\text { and nutritional status } \\
\text { on mortality in palliative } \\
\text { patients in our region. }\end{array}$ & $\begin{array}{l}\text { Malnutrition rate was determined as } 82.90 \% \text { for the patients } \\
\text { treated in PC units. }\end{array}$ \\
\hline $\begin{array}{l}\text { Bağçivan } \\
\text { [334] }\end{array}$ & Turkish & Thesis & Methodological & $\begin{array}{l}\text { To analyse the validity and } \\
\text { reliability of the Turkish } \\
\text { version of the Functional } \\
\text { Assessment of Chronic } \\
\text { Illness Therapy-Palliative } \\
\text { Care (FACIT-Pal) Scale. }\end{array}$ & $\begin{array}{l}\text { Turkish version of the Functional Assessment of Chronic } \\
\text { Illness Therapy-Palliative Care (FACIT-Pal) Scale is a reliable } \\
\text { scale and can be used to asses and monitor the PC-specific } \\
\text { quality of life in cancer patients. }\end{array}$ \\
\hline İlhan [335] & Turkish & Thesis & Cross-sectional & $\begin{array}{l}\text { To determine the effect of } \\
\text { burnout on the social lives } \\
\text { of relatives or carers who } \\
\text { provide continuous care } \\
\text { service as primary to PC } \\
\text { patients. }\end{array}$ & $\begin{array}{l}\text { As a result of our cultural values, we are able to reduce } \\
\text { mental/psychological health problems the most. It may } \\
\text { be possible to anticipate that the level of burnout and the } \\
\text { standard of living will improve as a result of social support } \\
\text { from the environment of cancer patients. }\end{array}$ \\
\hline $\begin{array}{l}\text { Öksüzoğlu } \\
{[336]}\end{array}$ & Turkish & Thesis & Cross-sectional & $\begin{array}{l}\text { To evaluate the } \\
\text { relationship between } \\
\text { depression-burnout level } \\
\text { and maintenance period } \\
\text { observed in caregivers of } \\
\text { PC patients. }\end{array}$ & $\begin{array}{l}\text { The rate of depression is higher in caregivers who care for } \\
\text { parents or partner. It was understood that the personal } \\
\text { success scores of the depressive cases were lower, extension } \\
\text { of the maintenance period and the inability to obtain support } \\
\text { from the family members facilitated the emergence of the } \\
\text { burnout situation. }\end{array}$ \\
\hline
\end{tabular}


Supplementary Table 1. Details of the included studies. (Continued).

\begin{tabular}{|c|c|c|c|c|c|}
\hline $\begin{array}{l}\text { Karadeniz } \\
\text { [337] }\end{array}$ & Turkish & Thesis & Cross-sectional & $\begin{array}{l}\text { To investigate the } \\
\text { effect of the PC service } \\
\text { provided in a well- } \\
\text { equipped PC centre } \\
\text { on the management of } \\
\text { different symptoms and } \\
\text { personal performance } \\
\text { levels. }\end{array}$ & $\begin{array}{l}\text { PC patients, who are experiencing many symptoms } \\
\text { simultaneously, are found to report only the most } \\
\text { discomforting symptom. PC units, approached the patient } \\
\text { in a holistic manner, and by providing symptom control, } \\
\text { increased the performance levels. }\end{array}$ \\
\hline $\begin{array}{l}\text { Kahraman } \\
\text { [338] }\end{array}$ & Turkish & Thesis & Cross-sectional & $\begin{array}{l}\text { To determine the factors } \\
\text { affecting the social } \\
\text { support perception of } \\
\text { the relatives of the PC } \\
\text { and oncology patients } \\
\text { receiving treatment in } \\
\text { hospital services, to } \\
\text { identify whether there } \\
\text { is difference in social } \\
\text { support perception } \\
\text { between two services, } \\
\text { to enlighten their } \\
\text { perceptions of social } \\
\text { support, contributing to } \\
\text { the filling of the lack of } \\
\text { information and literature } \\
\text { on social work in the } \\
\text { organisation of PC which } \\
\text { is very new in Turkey } \\
\text { and to draw attention to } \\
\text { the problems of patient } \\
\text { relatives. }\end{array}$ & $\begin{array}{l}\text { Reassessment of PC services, the need to deal with not } \\
\text { only patients but also their relatives, adaptation process to } \\
\text { illness, identical with the death, support during grief period } \\
\text { necessities in Turkey are mentioned. }\end{array}$ \\
\hline Kara [203] & Turkish & Thesis & Cross-sectional & $\begin{array}{l}\text { To determine the opinions } \\
\text { of terminal cancer } \\
\text { patients about PC. }\end{array}$ & $\begin{array}{l}\text { Eighty-seven point eight percent of the participants have } \\
\text { never heard of PC concept. Although most of the participants } \\
\text { (62.4\%) would like to look after their patients at home, they } \\
\text { prefer hospital care (79\%). }\end{array}$ \\
\hline Kado [339] & Turkish & Thesis & Cross-sectional & $\begin{array}{l}\text { To identify the problems } \\
\text { faced by patients and } \\
\text { their relatives who need } \\
\text { PC and to offer solutions }\end{array}$ & $\begin{array}{l}\text { The patient and the relatives of the patient faced various } \\
\text { troubles in the PC process such as communication problems } \\
\text { with physicians, nurses and health personnel. }\end{array}$ \\
\hline
\end{tabular}


Supplementary Table 1. Details of the included studies. (Continued).

\begin{tabular}{|c|c|c|c|c|c|}
\hline Güney [340] & Turkish & Thesis & Cross-sectional & $\begin{array}{l}\text { To contribute to the } \\
\text { integration process } \\
\text { of PC into Emergency } \\
\text { Department (ED) by } \\
\text { examining the needs and } \\
\text { symptom severities with } \\
\text { Speed, Edmonton and } \\
\text { Karnofsky scales by using } \\
\text { a new screening method } \\
\text { of patients who applied to } \\
\text { ED and who need PC. }\end{array}$ & $\begin{array}{l}\mathrm{PC} \text { is a maintenance that should not be ignored in the current } \\
\text { health system. It is not possible for emergency services alone } \\
\text { to undertake such care, but it is not possible to exclude } \\
\text { emergency services from this care. }\end{array}$ \\
\hline Filiz [341] & Turkish & Thesis & Cross-sectional & $\begin{array}{l}\text { To determine the } \\
\text { satisfaction levels of the } \\
\text { patients in the PC centre } \\
\text { in the health centres in } \\
\text { Ankara and the factors } \\
\text { affecting this level of } \\
\text { satisfaction. }\end{array}$ & $\begin{array}{l}\text { Completely dependent patients and patients who have had } \\
\text { previous experience of bed rest have higher satisfaction } \\
\text { levels. Better physical conditions of PC clinics, comfortable } \\
\text { single patient rooms and having materials that they may } \\
\text { need, positively affect patient satisfaction. In addition, } \\
\text { nursing care satisfaction levels of nurses with higher } \\
\text { education level, nurses with more clinical experience, and PC } \\
\text { clinics with higher number of nurses are higher. }\end{array}$ \\
\hline Saygılı [342] & Turkish & Thesis & Cross-sectional & $\begin{array}{l}\text { To evaluate the cost } \\
\text { effectiveness of the PC } \\
\text { services received by } \\
\text { cancer patients who need } \\
\text { PC with three different } \\
\text { service models. }\end{array}$ & $\begin{array}{l}\text { Receiving usual care at the public hospital was more cost } \\
\text { effective than receiving care at the Palliative Care Centre } \\
\text { from the social perspective. From the patient's perspective, } \\
\text { home health care services model was more cost effective } \\
\text { than the usual care at the public hospital model and the } \\
\text { Palliative Care Centre model. When the gains in terms of } \\
\text { quality of life were evaluated from the patient's perspective, } \\
\text { the most cost effective model became the home health } \\
\text { care services model again. When the patient satisfaction } \\
\text { level was evaluated from the patient's perspective, the most } \\
\text { cost-effective method was found as the usual care at public } \\
\text { hospital model. The most cost-effective model in terms of } \\
\text { the satisfaction levels and the care burdens of the families } \\
\text { was found as home health care services model. }\end{array}$ \\
\hline $\begin{array}{l}\text { Gürakan } \\
\text { [343] }\end{array}$ & Turkish & Thesis & Interventional & $\begin{array}{l}\text { To investigate the impact } \\
\text { of aromatherapy massage } \\
\text { on pain and plasma } \\
\text { beta-endorphin levels in } \\
\text { palliative cancer patients. }\end{array}$ & $\begin{array}{l}\text { Aromatherapy massage can decrease pain intensity and } \\
\text { increase plasma beta-endorphin levels in palliative cancer } \\
\text { patients. }\end{array}$ \\
\hline $\begin{array}{l}\text { Ahmed et I } \\
\text { [13] }\end{array}$ & Turkish & Thesis & Cross-sectional & $\begin{array}{l}\text { To comment on the use of } \\
\text { narcotic analgesics. }\end{array}$ & $\begin{array}{l}\text { Cancer pain is still one of the most feared entities in cancer } \\
\text { and about } 75 \% \text { of cancer patients with pain require treatment } \\
\text { with opioids for severe pain. }\end{array}$ \\
\hline
\end{tabular}


Supplementary Table 1. Details of the included studies. (Continued).

\begin{tabular}{|c|c|c|c|c|c|}
\hline Akyüz [344] & Turkish & Thesis & Cross-sectional & $\begin{array}{l}\text { To investigate if the } \\
\text { existence of a PC centre } \\
\text { in the hospital makes a } \\
\text { difference on the hospital } \\
\text { and healthcare giver } \\
\text { satisfaction of terminally } \\
\text { ill cancer patients. }\end{array}$ & $\begin{array}{l}\text { Having a PC centre in the hospital positively impact hospital } \\
\text { and healthcare provider satisfaction of the cancer patients. } \\
\text { The patients who are in PC centres do not have an intention } \\
\text { to switch to standard hospitals without any PC centres. } \\
\text { Additionally they would like to receive psychological support } \\
\text { during their treatment process. }\end{array}$ \\
\hline Uslu [345] & Turkish & Thesis & Cross-sectional & $\begin{array}{l}\text { To determine the PC } \\
\text { practices of the midwives } \\
\text { and nurses working in the } \\
\text { gynaecological oncology } \\
\text { units in Ankara. }\end{array}$ & $\begin{array}{l}\text { Hospitals with gynaecological oncology units in Ankara were } \\
\text { evaluated and it was suggested to enhance the awareness } \\
\text { of midwives and nurses on the PC, include the PC in the } \\
\text { graduate curriculum and on-job training programs, organise } \\
\text { a number of courses in this field and develop a number of } \\
\text { guidelines for symptomatic checks in PC. }\end{array}$ \\
\hline Özçelik [346] & Turkish & Thesis & Interventional & $\begin{array}{l}\text { To examine the effect of } \\
\text { case management model } \\
\text { on symptom level, quality } \\
\text { of life, patient and family } \\
\text { satisfaction, and direct } \\
\text { cost results in PC of } \\
\text { cancer patients. }\end{array}$ & $\begin{array}{l}\text { In PC of cancer patients, a better symptom control was } \\
\text { provided and their life quality was improved (excluding } \\
\text { physical and cognitive functions) through the use of Case } \\
\text { Management Model. Satisfaction level of patients and } \\
\text { families monitored by Case Management is higher. }\end{array}$ \\
\hline Turgay [347] & Turkish & Thesis & Cross-sectional & $\begin{array}{l}\text { To explore healthcare } \\
\text { professionals' knowledge } \\
\text { and views on PC. }\end{array}$ & $\begin{array}{l}53.7 \% \text { of the health professionals did not receive education } \\
\text { on PC. The barriers for development of the PC services in } \\
\text { Turkey were listed as ignorance ( } 44.4 \% \text { ) and lack of education } \\
\text { ( } 42.9 \%) \text {. PC should be provided in curricula and in-service } \\
\text { education programmes to increase awareness among } \\
\text { healthcare professionals. }\end{array}$ \\
\hline Çakıcı [83] & Turkish & Thesis & Cross-sectional & $\begin{array}{l}\text { To evaluate the } \\
\text { knowledge of the } \\
\text { physicians and nurses for } \\
\text { PC and PC practices of } \\
\text { them for children with } \\
\text { end-stage cancer. }\end{array}$ & $\begin{array}{l}76 \%-93 \% \text { of the participants showed correct approach } \\
\text { in management of the other symptoms. Only } 19 \% \text { of the } \\
\text { participants stated that their abilities in end-stage care were } \\
\text { sufficient and } 82 \% \text { of them indicated that they needed } \\
\text { training in end-of-life care. }\end{array}$ \\
\hline $\begin{array}{l}\text { Ekici } \\
\text { Kocakafa } \\
\text { [348] }\end{array}$ & Turkish & Thesis & Cross-sectional & $\begin{array}{l}\text { To determine the } \\
\text { relationship between } \\
\text { the socio-demographic } \\
\text { characteristics of } \\
\text { caregivers and their } \\
\text { burden of care. }\end{array}$ & $\begin{array}{l}\text { Increased duration of patient care, lack of social security, } \\
\text { increased number of people in need of home care outside } \\
\text { the patient, negative effects of family dynamics during the } \\
\text { caregiving process, increased weight of patient resulted in an } \\
\text { increase in Burden Interview Score. }\end{array}$ \\
\hline $\begin{array}{l}\text { Karabuğa } \\
\text { [349] }\end{array}$ & Turkish & Thesis & Methodological & $\begin{array}{l}\text { To evaluate reliability } \\
\text { and validity of The } \\
\text { Caregiver Quality of Life } \\
\text { Index-Cancer Scale and } \\
\text { to investigate quality of } \\
\text { life and factors related } \\
\text { to quality of life among } \\
\text { caregivers of patients } \\
\text { with cancer. }\end{array}$ & $\begin{array}{l}\text { The Caregiver Quality of Life Index is valid and reliable. } \\
\text { Caregivers who were female, old, had financial difficulties } \\
\text { and had difficulties to continue their routine responsibilities } \\
\text { or duties and who weren't supported had lower quality of life } \\
\text { scores. }\end{array}$ \\
\hline
\end{tabular}


Supplementary Table 1. Details of the included studies. (Continued).

\begin{tabular}{|c|c|c|c|c|c|}
\hline Çalışkan [350] & Turkish & Thesis & Cross-sectional & $\begin{array}{l}\text { To determine the } \\
\text { efficiency of Algology } \\
\text { Department, by assessing } \\
\text { the cancer patients, } \\
\text { their doctors and nurses } \\
\text { working in some of the } \\
\text { surgical and oncology } \\
\text { departments of Hacettepe } \\
\text { University Faculty of } \\
\text { Medicine. }\end{array}$ & $\begin{array}{l}61.9 \% \text { of the patients were suffering from pain. After } \\
\text { the follow-up, } 88.6 \% \text { of the patients, } 70 \% \text { of whom were } \\
\text { informed about the treatment of cancer pain by the doctors } \\
\text { and nurses of Algology Department, mentioned that their } \\
\text { complaints had partially or completely passed. } 78.8 \% \\
\text { of nurses had joined the education programmes after } \\
\text { graduation which were given by Algology Department. } 65 \% \\
\text { of the doctors were at least seeing a patient once a week } \\
\text { suffering from cancer pain but most of them were found } \\
\text { not to have adequate education about cancer pain and its } \\
\text { treatment during their medical school or residency training. }\end{array}$ \\
\hline Elevli [351] & Turkish & Thesis & Cross-sectional & $\begin{array}{l}\text { To quantify the } \\
\text { dependency ratio of } \\
\text { geriatrics group, and } \\
\text { to specify the need of } \\
\text { home care service by } \\
\text { designating the needs } \\
\text { assessment. }\end{array}$ & $\begin{array}{l}\text { Home care services, ageing and its problems, population } \\
\text { growth of aged people, nursing of aged people, and palliative } \\
\text { and hospice care services which are related to terminal } \\
\text { period of cancer are discussed. Our country's need for care } \\
\text { services and its current state have been attempted to be } \\
\text { determined by examining the examples in Turkey and the } \\
\text { world. By considering that cancer patients and geriatric group } \\
\text { need home care service, the service area has been attempted } \\
\text { to be specified. }\end{array}$ \\
\hline Kılınç [352] & Turkish & Thesis & Cross-sectional & $\begin{array}{l}\text { To analyse admission rate, } \\
\text { prognosis, mortality rates, } \\
\text { risk factors affecting } \\
\text { mortality and cost per } \\
\text { patient of cancer patients } \\
\text { followed in Pamukkale } \\
\text { University Faculty of } \\
\text { Medicine Anestesiology } \\
\text { Intensive Care Unit. }\end{array}$ & $\begin{array}{l}\text { The most common reason for admission was respiratory } \\
\text { failure (63.3\%), followed by sepsis ( } 16.3 \% \text { ) and cardiac arrest } \\
\text { (5.17\%). Cost per patient per day in ICU was between 186.9- } \\
4407.4 \text { TL and mean cost was } 1,628.5 \pm 524.1 \text { TL. Mortality } \\
\text { rate of these cancer patients was } 89.2 \% \text {. }\end{array}$ \\
\hline $\begin{array}{l}\text { Uzunkaya } \\
\text { [353] }\end{array}$ & Turkish & Thesis & Cross-sectional & $\begin{array}{l}\text { To determine attitudes } \\
\text { of nurses, working in } \\
\text { oncology clinics, towards } \\
\text { care of dying patient and } \\
\text { principles about death } \\
\text { with dignity and their } \\
\text { opinions regarding good } \\
\text { death. }\end{array}$ & $\begin{array}{l}\text { Nurses' most important difficulty in giving care to the dying } \\
\text { patient was communication with patients and their relatives. } \\
\text { Attitudes of nurses towards giving care to the dying patient } \\
\text { were more positive ( } t=4.900 ; p=0.001) \text {. Good death score } \\
\text { median of female nurses was higher male nurses ( } p=0.001 \text { ). } \\
\text { There was a negative weak correlation ( } r=-0,158 ; p=0.011 \text { ) } \\
\text { between nurses' level of adopting principles about death with } \\
\text { dignity and their perceptions about good death; a positive } \\
\text { weak correlation between attitudes of nurses for giving care } \\
\text { to the dying patient and psychosocial-spiritual }(r=0.124 ; p \\
=0.011 \text { ) and self-control subscales }(r=0.172 ; p=0.006 \text { ) of } \\
\text { death. }\end{array}$ \\
\hline Terzi [354] & Turkish & Thesis & Qualitative & $\begin{array}{l}\text { To determine the views } \\
\text { of patients with cancer } \\
\text { and their nurses regarding } \\
\text { end-of-life care and to } \\
\text { contribute to the care } \\
\text { needs of patients. }\end{array}$ & $\begin{array}{l}\text { In general, patients and nurses defined end-of-life care as a } \\
\text { time when painless death is near, physical and psychological } \\
\text { needs increase and team collaboration is absolutely } \\
\text { necessary. Although nurses want to provide the necessary } \\
\text { care, they are not able to do so due to excess workload. }\end{array}$ \\
\hline
\end{tabular}


Supplementary Table 1. Details of the included studies. (Continued).

\begin{tabular}{|c|c|c|c|c|c|}
\hline Yalçın [355] & Turkish & Thesis & Cross-sectional & $\begin{array}{l}\text { To evaluate end-stage } \\
\text { patients admitted to the } \\
\text { Anesthesia Intensive Care } \\
\text { Unit, and their intensive } \\
\text { care procedures, including } \\
\text { PC receiving score and } \\
\text { life expectancy according } \\
\text { to palliative prognostic } \\
\text { index, mortality rates } \\
\text { and risk factors affecting } \\
\text { mortality, including } \\
\text { per patient costs by a } \\
\text { prospective analysis. }\end{array}$ & $\begin{array}{l}\text { The most common primary disease for intensive care } \\
\text { admission was malignancy. The average cost of treatment for } \\
\text { exitus patients was } \$ 3,654.50 \text {, while the cost of treatment } \\
\text { for surviving patients was } \$ 7,053.38 \text {. Patients who are dying } \\
\text { or refusing treatment due to terminal diseases, determined } \\
\text { using the necessary prognostic scoring systems, should } \\
\text { decide together with their primer physician and be admitted } \\
\text { to a PC unit or hospice. }\end{array}$ \\
\hline $\begin{array}{l}\text { Özyalçın } \\
\text { [356] }\end{array}$ & Turkish & Thesis & Cross-sectional & $\begin{array}{l}\text { To find out about the } \\
\text { opinions of cancer } \\
\text { patients, their relatives } \\
\text { and nurses about death } \\
\text { and good-death. }\end{array}$ & $\begin{array}{l}\text { The nurses have defined the death as function interruption } \\
\text { physically while the patients and patient relatives have } \\
\text { defined the good death as living without suffering. Patients' } \\
\text { views about good death were found to be more positive, } \\
\text { fear of death and avoidance behaviors were lower and } \\
\text { meaningful. Nurses have more fear of death and avoidance of } \\
\text { death. Therefore, comprehensive care should be given to the } \\
\text { end-of-life care of nurses. }\end{array}$ \\
\hline Şipal [357] & Turkish & Thesis & Cross-sectional & $\begin{array}{l}\text { To determine the } \\
\text { relationship between } \\
\text { supportive care needs } \\
\text { and disease acceptance } \\
\text { levels of patients with } \\
\text { haematological cancer. }\end{array}$ & $\begin{array}{l}\text { The difference between the perception of social support, } \\
\text { age, number of cures and outpatient or inpatient treatment } \\
\text { and disease acceptance level of the patients were statistically } \\
\text { significant. On the other hand, supportive maintenance } \\
\text { requirements; sex, marital status, income level, social support } \\
\text { perception, presence of chronic disease, metastasis status, } \\
\text { outpatient or inpatient treatment had been found to be } \\
\text { affecting. When the need for mental and physical care of } \\
\text { the patients increased, the acceptance level of the disease } \\
\text { decreased. }\end{array}$ \\
\hline $\begin{array}{l}\text { Palliative Care } \\
\text { Association } \\
{[25]}\end{array}$ & Turkish & NGO Website & - & $\begin{array}{l}\text { The establishment's } \\
\text { purpose was to provide } \\
\text { care for patients with } \\
\text { cancer and to ensure } \\
\text { the establishment and } \\
\text { development of PC } \\
\text { services across the } \\
\text { country. }\end{array}$ & $\begin{array}{l}\text { Palliative Care Association was established in Istanbul on } \\
4-12-2005 \text {, The main objective was to support the formation } \\
\text { of the necessary structures to provide PC. Association helped } \\
\text { to develop cooperation between physicians and healthcare } \\
\text { professionals. It also publishes magazines, brochures, } \\
\text { bulletins. The member advised the MoH in formulating } \\
\text { policies related to PC. Joint projects have been carried out } \\
\text { with national and international organisations. }\end{array}$ \\
\hline $\begin{array}{l}\text { Keskinkılıc } \\
\text { et al [29] }\end{array}$ & English & $\begin{array}{l}\text { Turkey Cancer } \\
\text { Control } \\
\text { Programme }\end{array}$ & - & $\begin{array}{l}\text { Structure and Principals of } \\
\text { National Cancer Control } \\
\text { Programme. }\end{array}$ & $\begin{array}{l}\text { A comprehensive National Cancer Control Programme } \\
\text { regarding the cancer registry, early detection, and treatment } \\
\text { of the cases, development of treatment guidelines enable } \\
\text { symptom control and high quality of life as much as possible } \\
\text { for the patients at an advanced stage. }\end{array}$ \\
\hline
\end{tabular}


Supplementary Table 1. Details of the included studies. (Continued).

\begin{tabular}{|c|c|c|c|c|c|}
\hline $\begin{array}{l}\text { Turkish } \\
\text { Ministry of } \\
\text { Health [30] }\end{array}$ & Turkish & $\begin{array}{l}\text { Legislation/ } \\
\text { regulation }\end{array}$ & - & $\begin{array}{l}\text { Quality standards for } \\
\text { healthcare training/ } \\
\text { education and } \\
\text { implementation of the } \\
\text { evaluation plan. }\end{array}$ & $\begin{array}{l}\text { Training programme for the nurses to acquire the knowledge, } \\
\text { skills and attitudes required to provide PC for patients and } \\
\text { their families. }\end{array}$ \\
\hline $\begin{array}{l}\text { The } \\
\text { Presidency of } \\
\text { the Republic } \\
\text { of Turkey [31] }\end{array}$ & Turkish & $\begin{array}{l}\text { The Official } \\
\text { Gazette }\end{array}$ & - & $\begin{array}{l}\text { Organisation and job } \\
\text { description. }\end{array}$ & $\begin{array}{l}\text { Job descriptions of the General Directorate of Public Health } \\
\text { and the General Directorate of Public Hospitals. The duties } \\
\text { of the General Directorate of Public Hospitals are; to ensure } \\
\text { the execution of all kinds of preventive, diagnosis, treatment } \\
\text { and rehabilitative health services in health institutions, and to } \\
\text { evaluate the activities, to follow good practice. }\end{array}$ \\
\hline $\begin{array}{l}\text { General } \\
\text { Directorate } \\
\text { of Public } \\
\text { Hospitals [32] }\end{array}$ & Turkish & MoH website & - & $\begin{array}{l}\text { Procedures and practice } \\
\text { related to Home Health } \\
\text { Services. }\end{array}$ & $\begin{array}{l}\text { 'Home Health and Palliative Care Unit' has established under } \\
\text { the General Directorate of Public Hospitals Health Services } \\
\text { Department. }\end{array}$ \\
\hline $\begin{array}{l}\text { The Prime } \\
\text { Minister's } \\
\text { office of the } \\
\text { Republic of } \\
\text { Turkey [36] }\end{array}$ & Turkish & $\begin{array}{l}\text { The Official } \\
\text { Gazette }\end{array}$ & - & $\begin{array}{l}\text { The scope, basis, } \\
\text { definitions and principles } \\
\text { of patient rights } \\
\text { regulations in Turkey. }\end{array}$ & $\begin{array}{l}\text { The principles and procedures for ensuring that everyone can } \\
\text { benefit from patient rights, to be protected from violations } \\
\text { of rights, and, when necessary, to use legal safeguards as } \\
\text { necessary. }\end{array}$ \\
\hline $\begin{array}{l}\text { The } \\
\text { Presidency of } \\
\text { the Republic } \\
\text { of Turkey [37] }\end{array}$ & Turkish & $\begin{array}{l}\text { The Official } \\
\text { Gazette }\end{array}$ & - & $\begin{array}{l}\text { To regulate the } \\
\text { procedures and principles } \\
\text { that the institutions } \\
\text { and organisations, must } \\
\text { comply with to provide } \\
\text { home care services. }\end{array}$ & $\begin{array}{l}\text { Continuity of home care is essential and should be available } \\
24 \text { hours including weekends and holidays. The person } \\
\text { who wants to receive home care can apply to the health } \\
\text { institution in person or by phone. The call centre interviews } \\
\text { the person requesting services and provides the necessary } \\
\text { information. The person who wants to receive care at home } \\
\text { will be visited by a physician and nurse. The care needs of the } \\
\text { person and home conditions will be determined and a home } \\
\text { care treatment plan will be developed. If necessary, patient } \\
\text { consultation will be provided with specialist physicians. }\end{array}$ \\
\hline $\begin{array}{l}\text { Turkish } \\
\text { Ministry of } \\
\text { Health [38] }\end{array}$ & Turkish & Directive & - & $\begin{array}{l}\text { Directive on the } \\
\text { Implementation } \\
\text { Procedures and Principles } \\
\text { of Home Health Services } \\
\text { Offered by the Ministry of } \\
\text { Health. }\end{array}$ & $\begin{array}{l}\text { The Ministry of Health will provide medical care, } \\
\text { rehabilitation, social and psychological support services to } \\
\text { those individuals and family members who need home health } \\
\text { services through establishing home healthcare units within } \\
\text { the affiliated health institutions. }\end{array}$ \\
\hline $\begin{array}{l}\text { Turkish } \\
\text { Ministry of } \\
\text { Health [39] }\end{array}$ & Turkish & Directive & - & $\begin{array}{l}\text { Applicatıon procedures } \\
\text { and prıncıples of PC } \\
\text { services. }\end{array}$ & $\begin{array}{l}\text { The purpose of this directive is to early identification of } \\
\text { pain and other symptoms in patients having life-threatening } \\
\text { diseases and to provide medical, psychological, social and } \\
\text { moral support to these patients and their family members. } \\
\text { To establish PC centres define their functioning and } \\
\text { physical conditions, the minimum standard of equipment } \\
\text { and personnel. To determine the procedures and principles } \\
\text { regarding the duty, authority, and responsibilities of the } \\
\text { pallıatıve care services. }\end{array}$ \\
\hline
\end{tabular}


Supplementary Table 1. Details of the included studies. (Continued).

\begin{tabular}{|c|c|c|c|c|c|}
\hline $\begin{array}{l}\text { The } \\
\text { Presidency of } \\
\text { the Republic } \\
\text { of Turkey [40] }\end{array}$ & Turkish & $\begin{array}{l}\text { The Official } \\
\text { Gazette }\end{array}$ & - & $\begin{array}{l}\text { The notification } \\
\text { for amending the } \\
\text { Social Security } \\
\text { Institution Healthcare } \\
\text { Implementation. }\end{array}$ & $\begin{array}{l}\text { The necessary criteria have been determined for } \\
\text { the evaluation of PC treatment within the scope of } \\
\text { reimbursement. The first of these criteria is that the relevant } \\
\text { health facility must be registered by the Ministry of Health to } \\
\text { provide PC. }\end{array}$ \\
\hline $\begin{array}{l}\text { The } \\
\text { Presidency of } \\
\text { the Republic } \\
\text { of Turkey [41] }\end{array}$ & Turkish & $\begin{array}{l}\text { The Official } \\
\text { Gazette }\end{array}$ & - & $\begin{array}{l}\text { This Regulation covers } \\
\text { the institutions and } \\
\text { organisations that provide } \\
\text { home health services and } \\
\text { is related to the provision } \\
\text { of this service. }\end{array}$ & $\begin{array}{l}\text { The purpose of this Regulation; to determine the procedures } \\
\text { and principles for ensuring coordination between institutions } \\
\text { and organisations related to the provision, referral and } \\
\text { administration of home health services (medical care, } \\
\text { rehabilitation, social and psychological support to patients } \\
\text { and their family members) provided by the Ministry and its } \\
\text { affiliated institutes. }\end{array}$ \\
\hline $\begin{array}{l}\text { The } \\
\text { Presidency of } \\
\text { the Republic } \\
\text { of Turkey [45] }\end{array}$ & Turkish & $\begin{array}{l}\text { The Official } \\
\text { Gazette }\end{array}$ & - & $\begin{array}{l}\text { Regulation for the } \\
\text { establishment of Ege } \\
\text { University Palliative Care } \\
\text { Application and Research } \\
\text { Center. }\end{array}$ & $\begin{array}{l}\text { This Regulation covers the provisions regarding the } \\
\text { objectives, fields of activity, governing bodies, duties of } \\
\text { management bodies and working principles of Ege University } \\
\text { Palliative Care Application and Research Center. }\end{array}$ \\
\hline $\begin{array}{l}\text { Palliative } \\
\text { Care Nurses } \\
\text { Association } \\
\text { [48] }\end{array}$ & Turkish & NGO Website & - & $\begin{array}{l}\text { To increase the } \\
\text { professional knowledge } \\
\text { and experience in the } \\
\text { field of } \mathrm{PC} \text {, monitor the } \\
\text { developments in nursing } \\
\text { practices. }\end{array}$ & $\begin{array}{l}\text { The PC nurses association was founded in 2019. The } \\
\text { Association organises congresses, conferences, seminars and } \\
\text { symposiums related to PC nursing. Cooperates with relevant } \\
\text { national and international institutions and organisations. } \\
\text { Publishes magazines, brochures. Determines the principles of } \\
\text { professional practice, ethical rules, standards of application, } \\
\text { in the field of PC. Organises activities for patients, their } \\
\text { families and society to improve awareness and quality of life. }\end{array}$ \\
\hline
\end{tabular}


Supplementary Table 2. Scales used as assessment tool in PC for cancer research in Turkey.

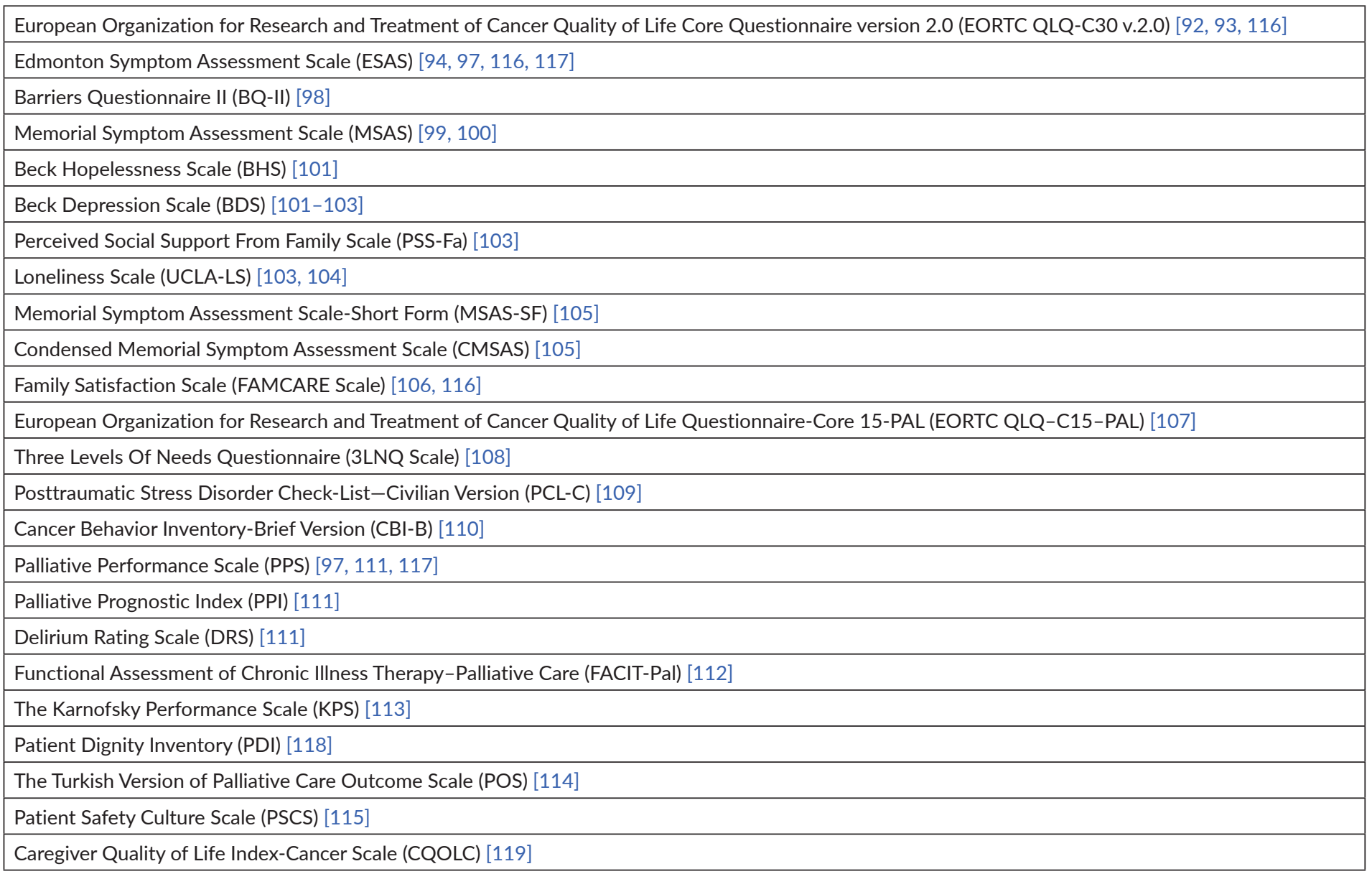

